
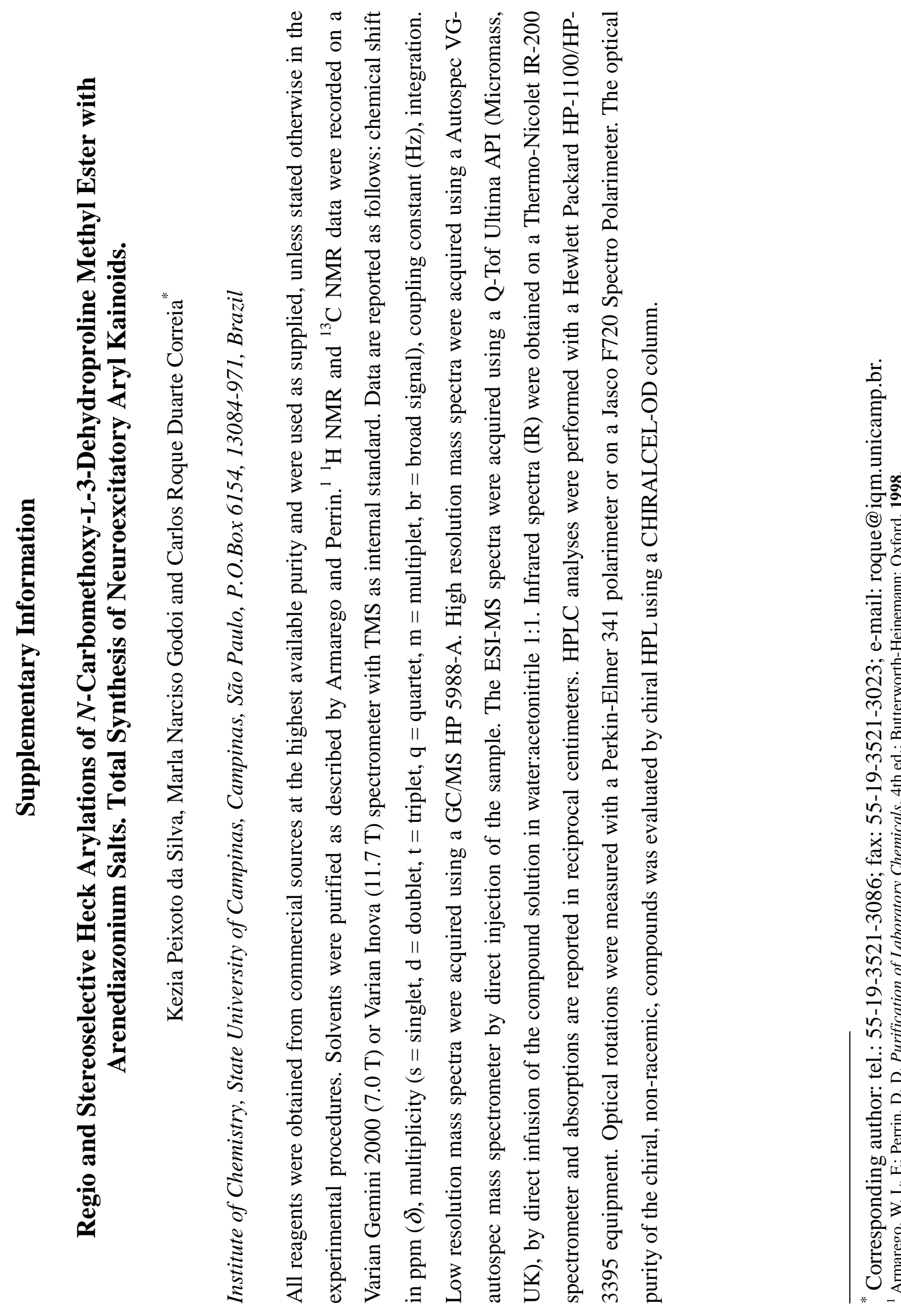
ن.

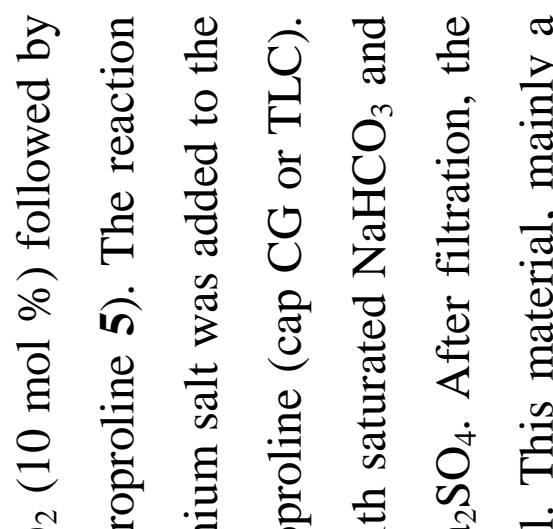

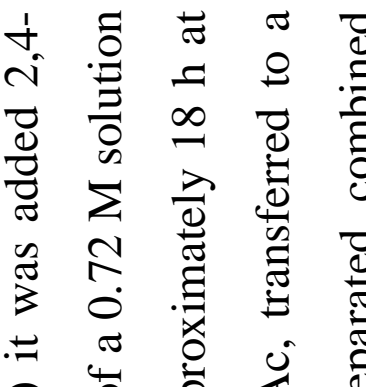

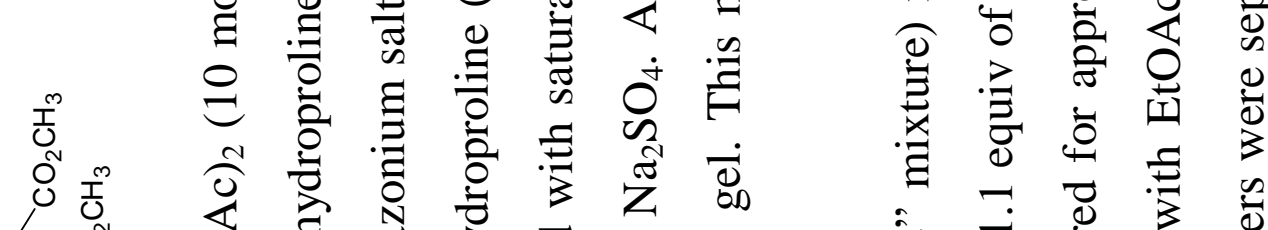

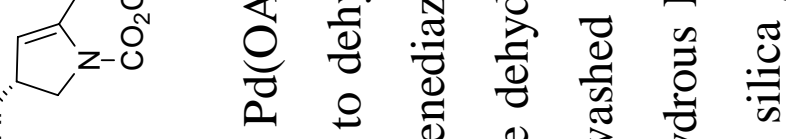

ミ゙

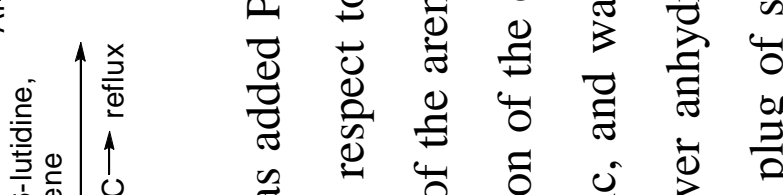

ส

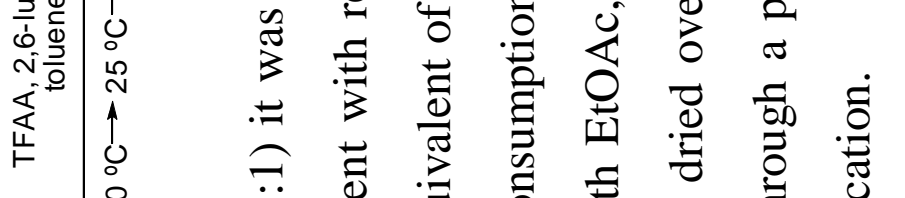

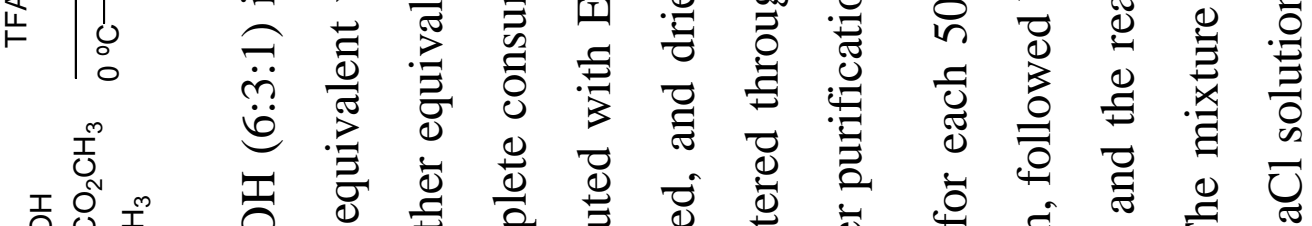

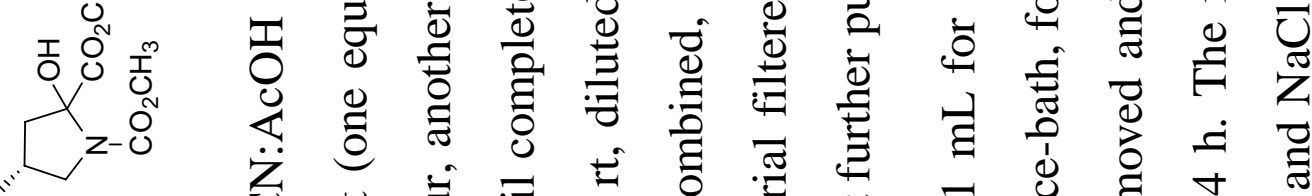

芒

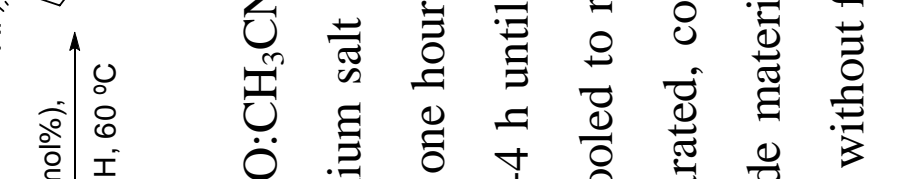

छ

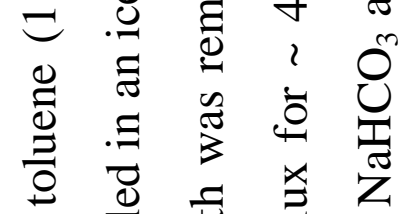

岗主员

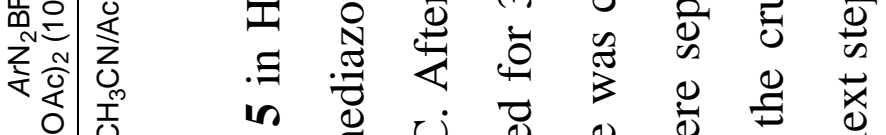

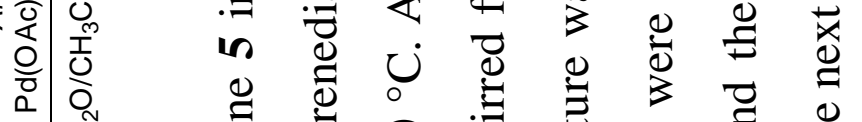

일

䎡 竞

j)

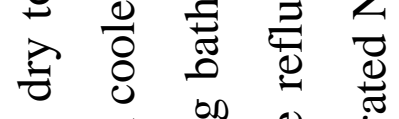

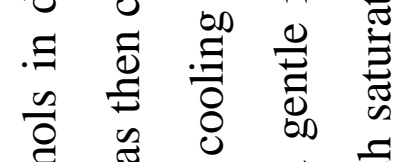

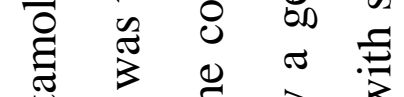

总

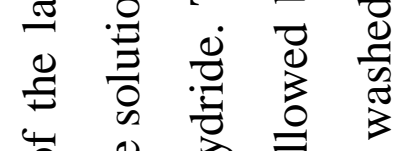

4 ○

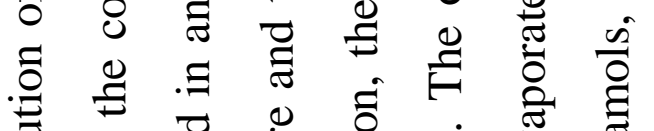

苍 き

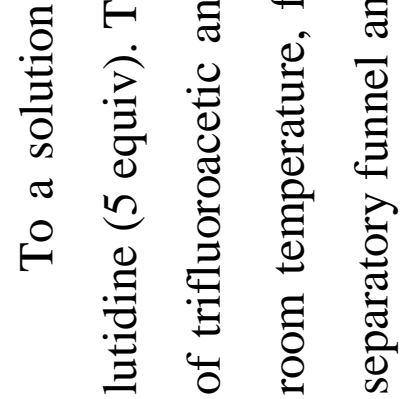




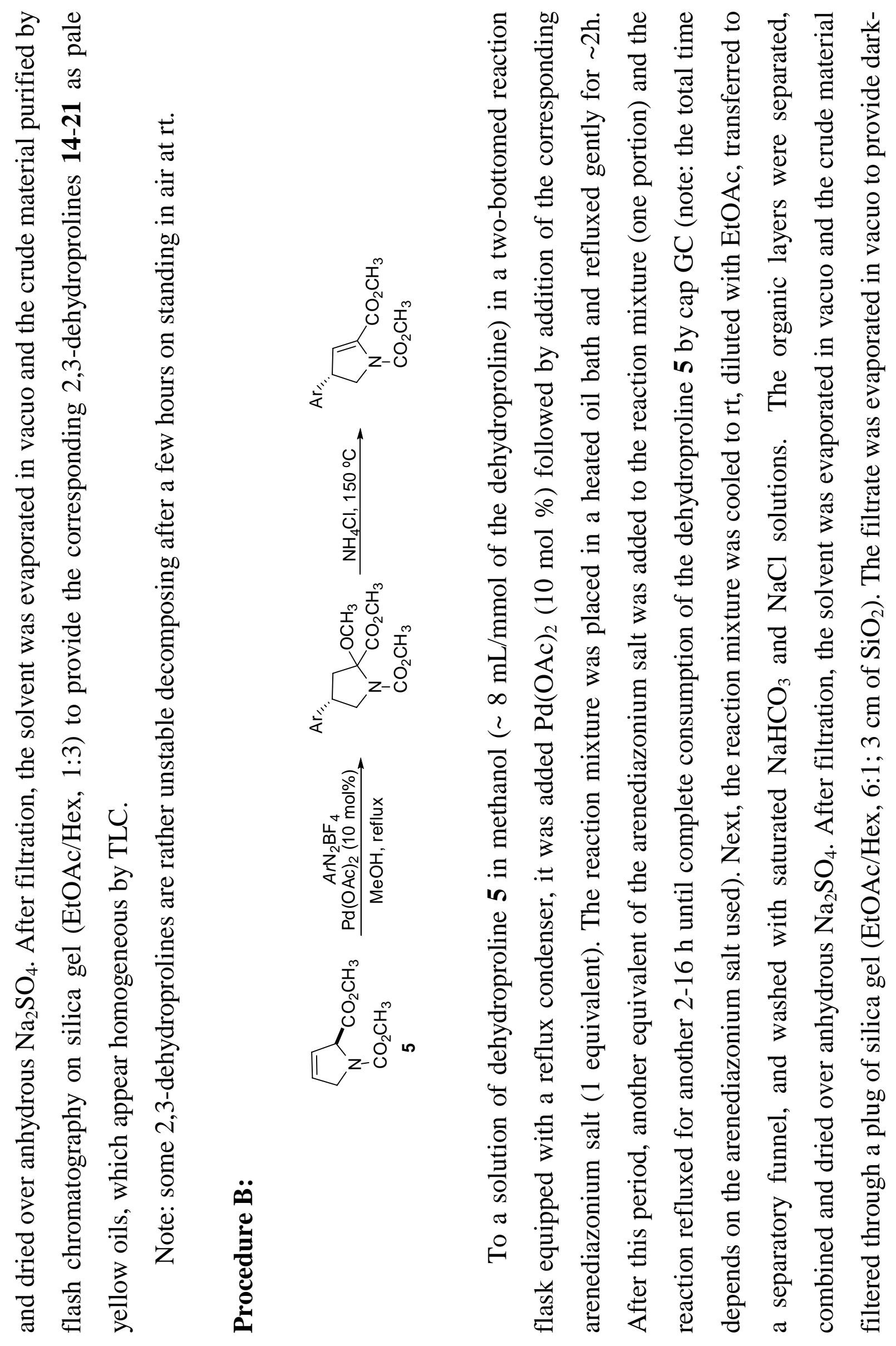




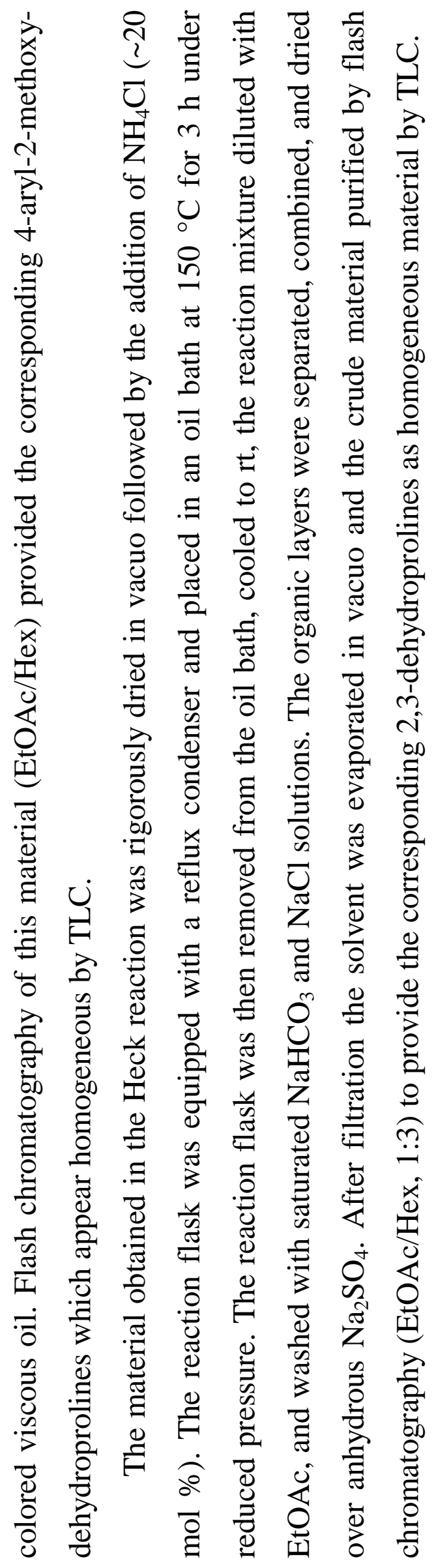



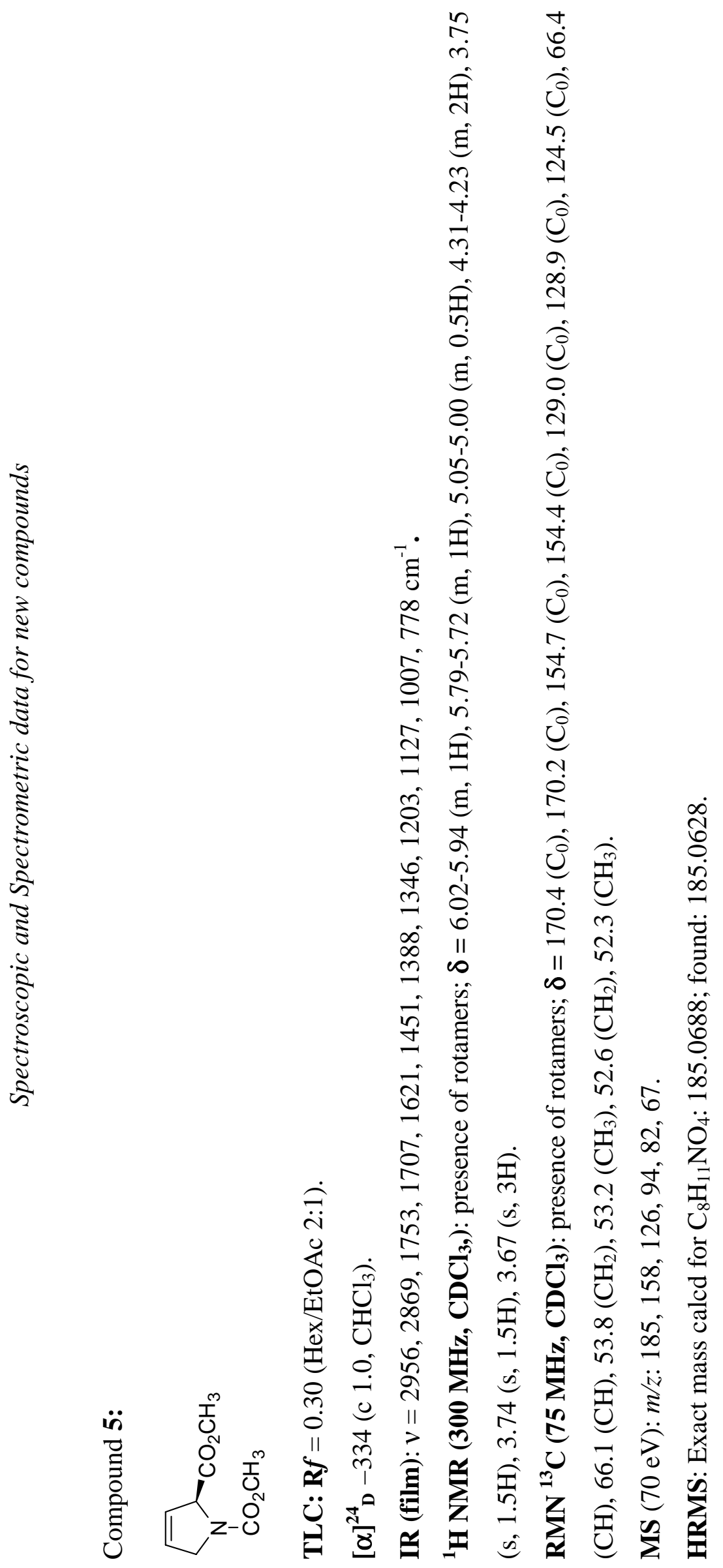


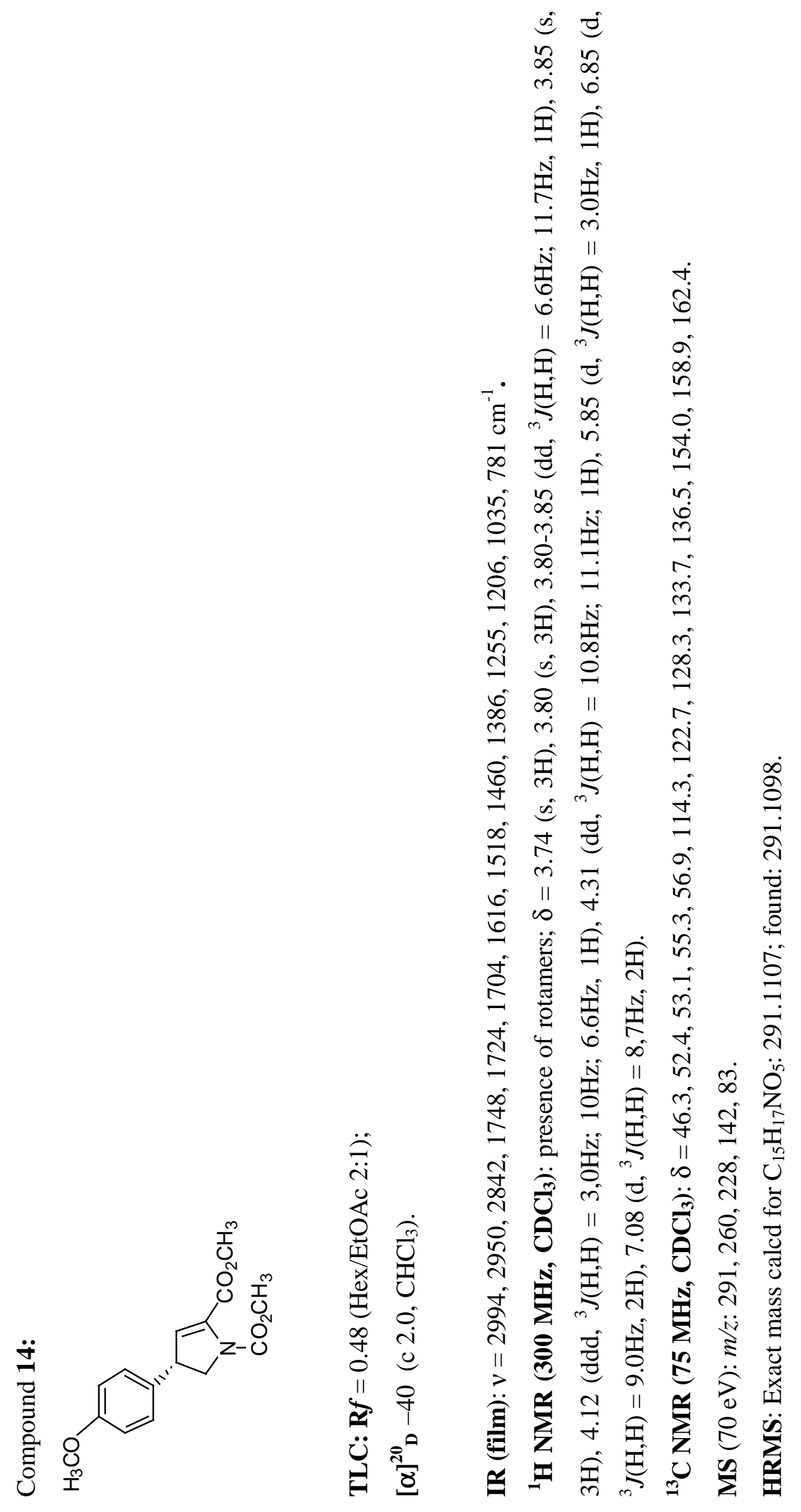




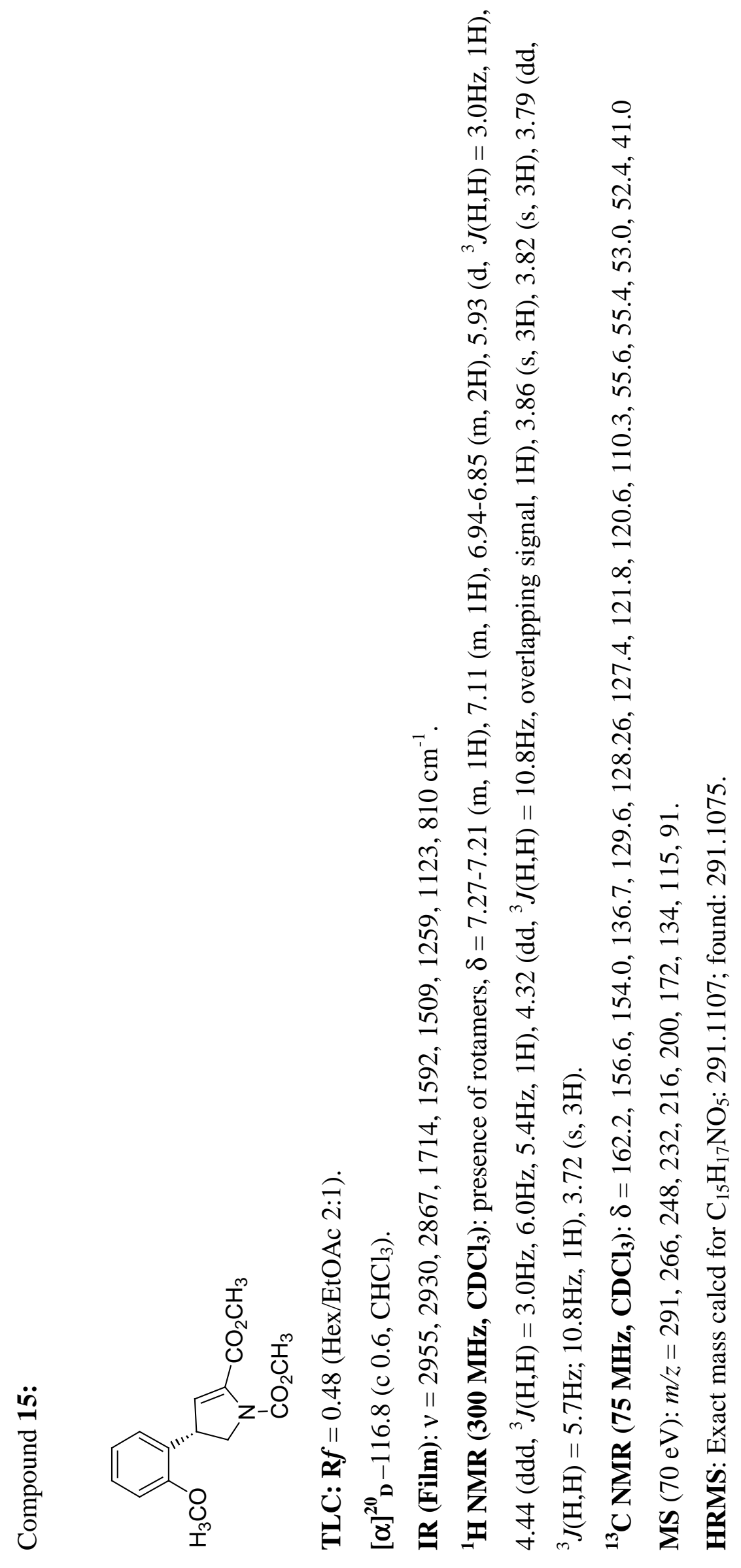




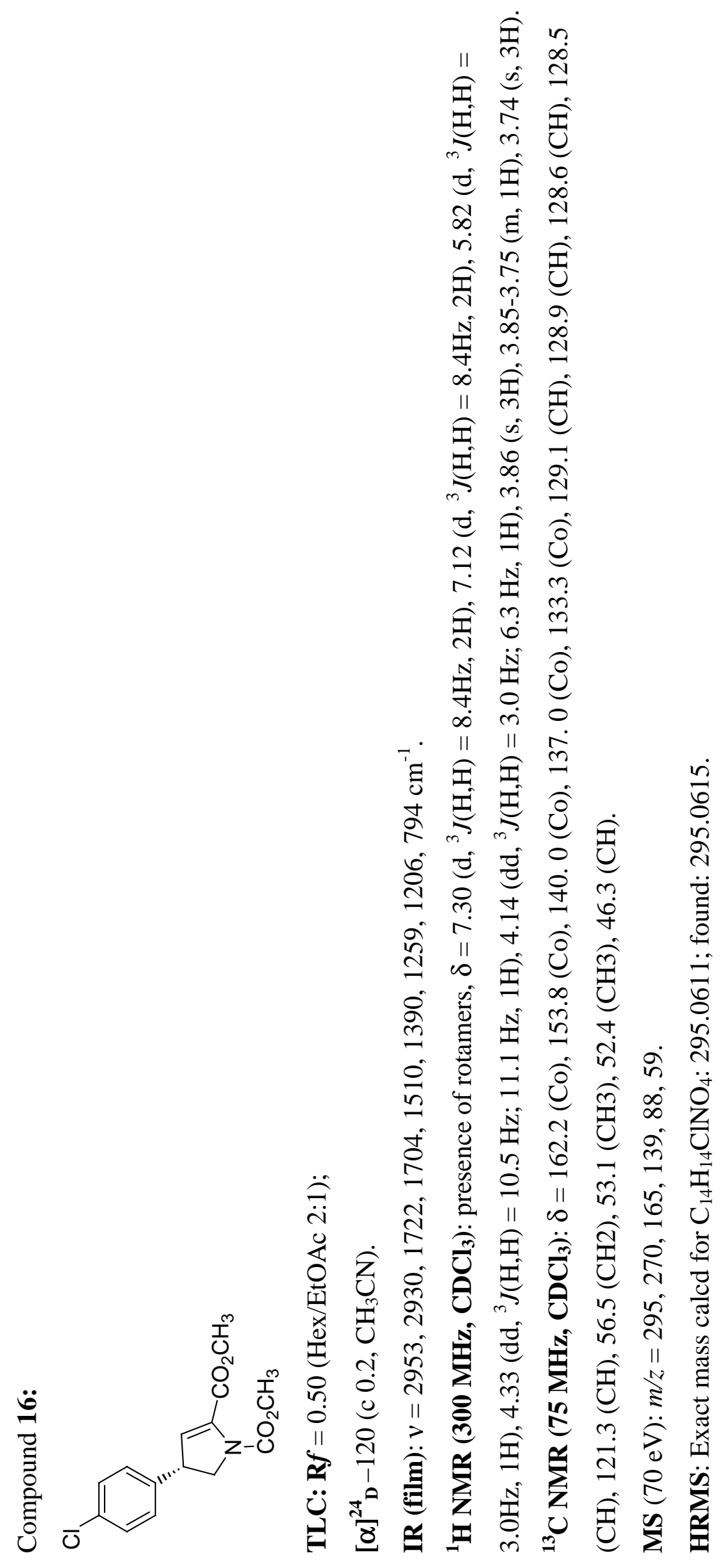




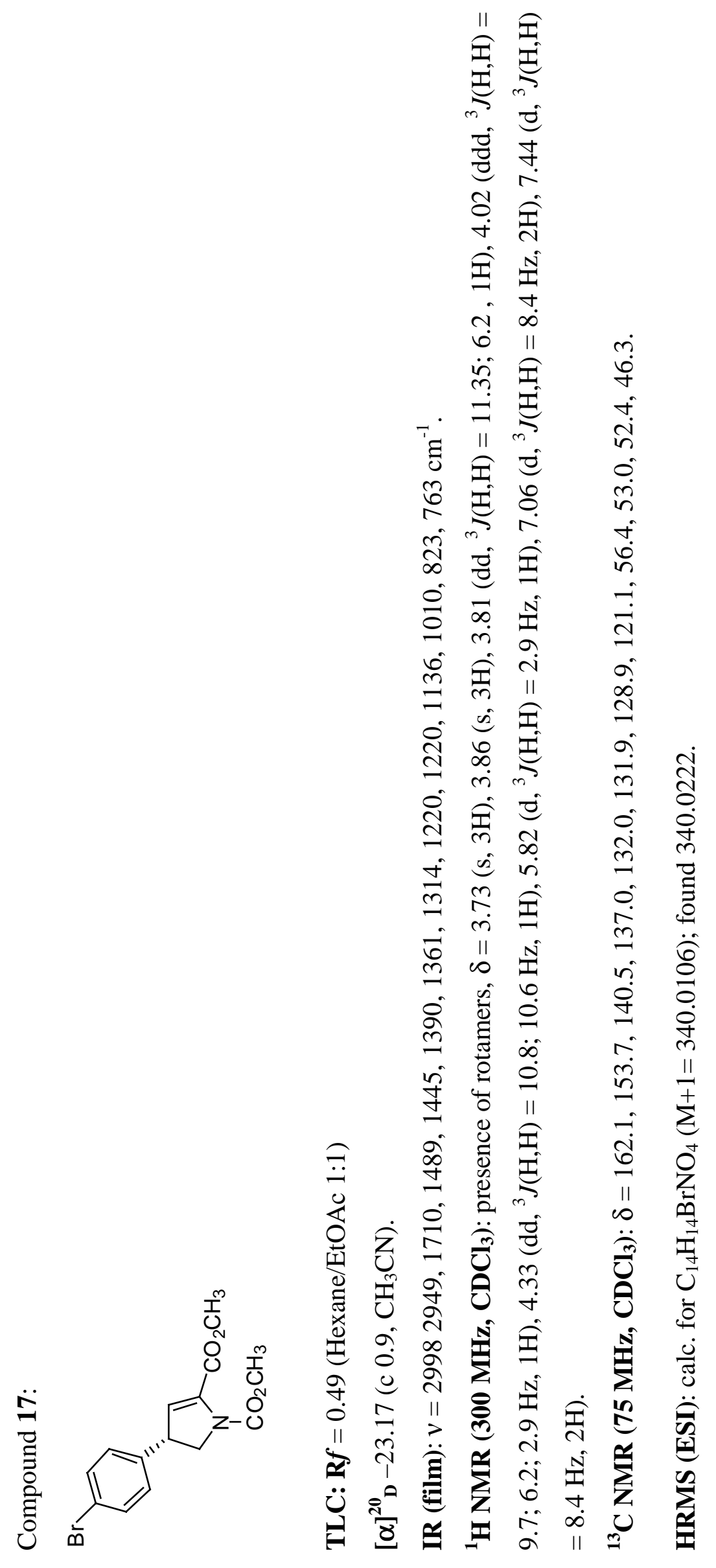




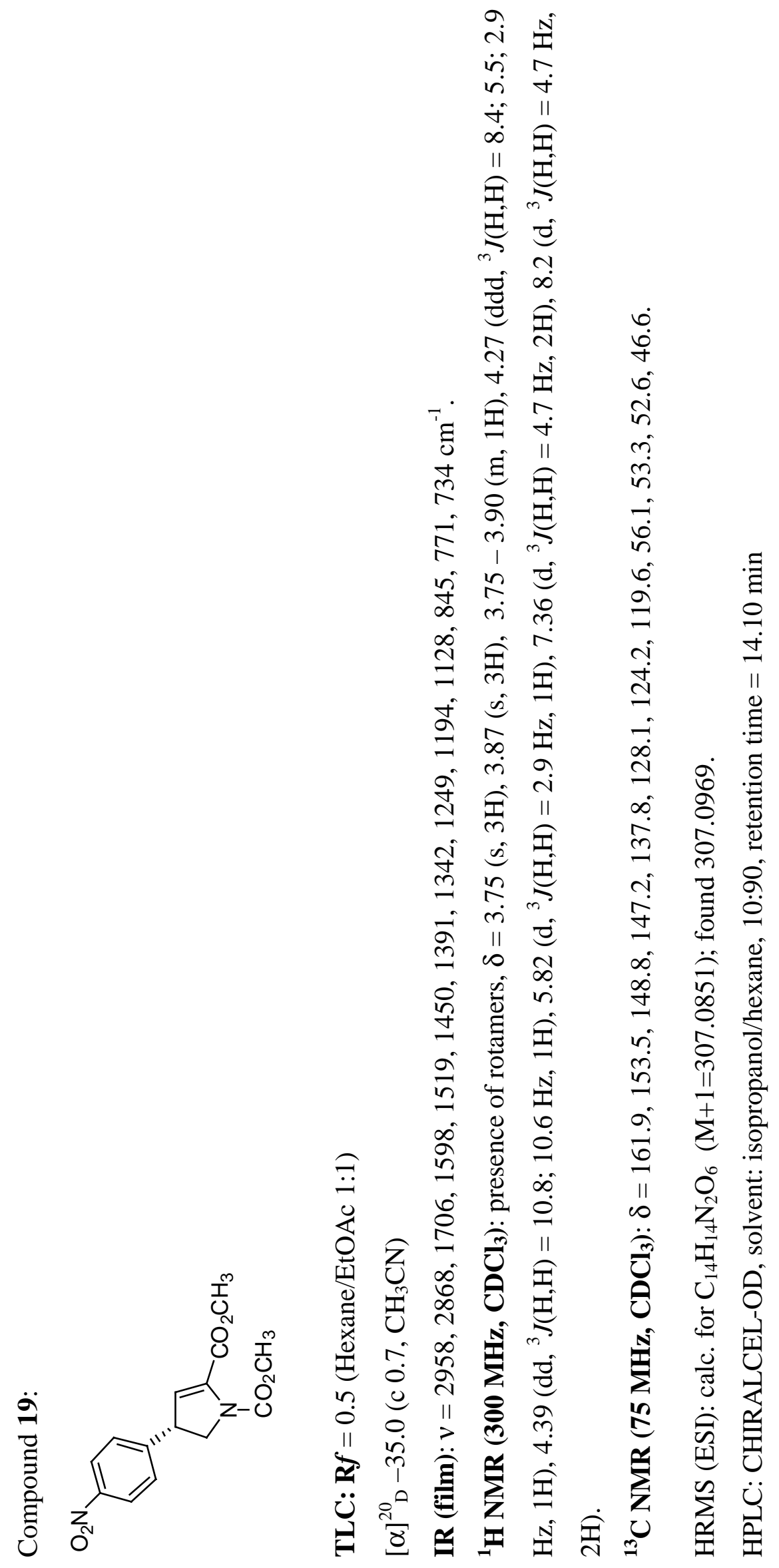




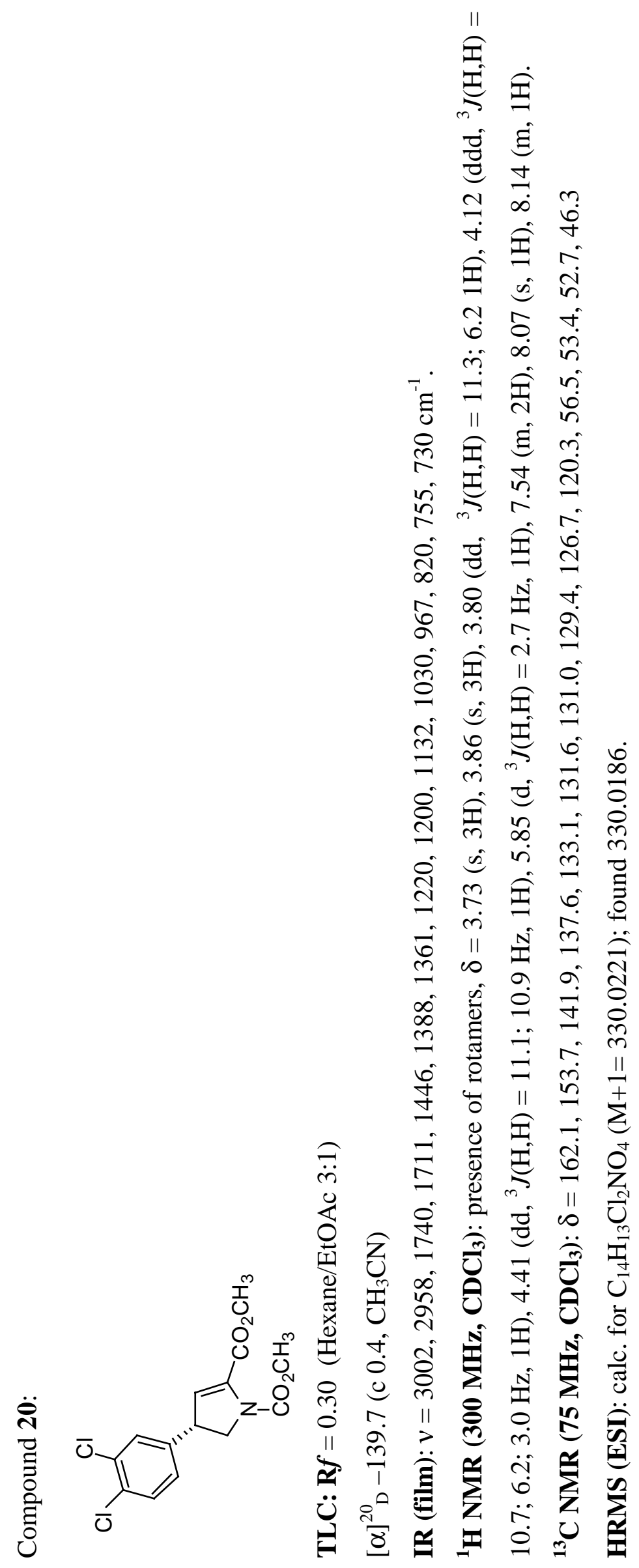




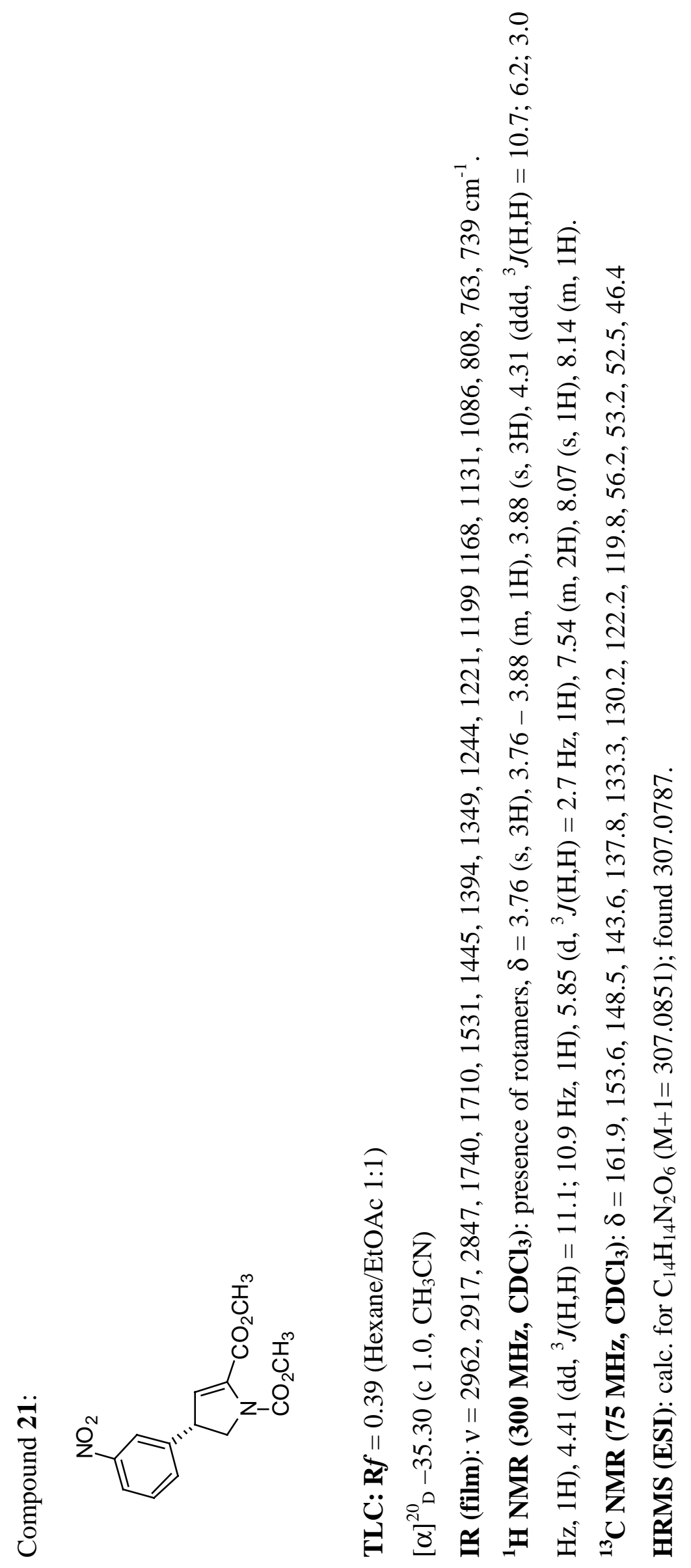




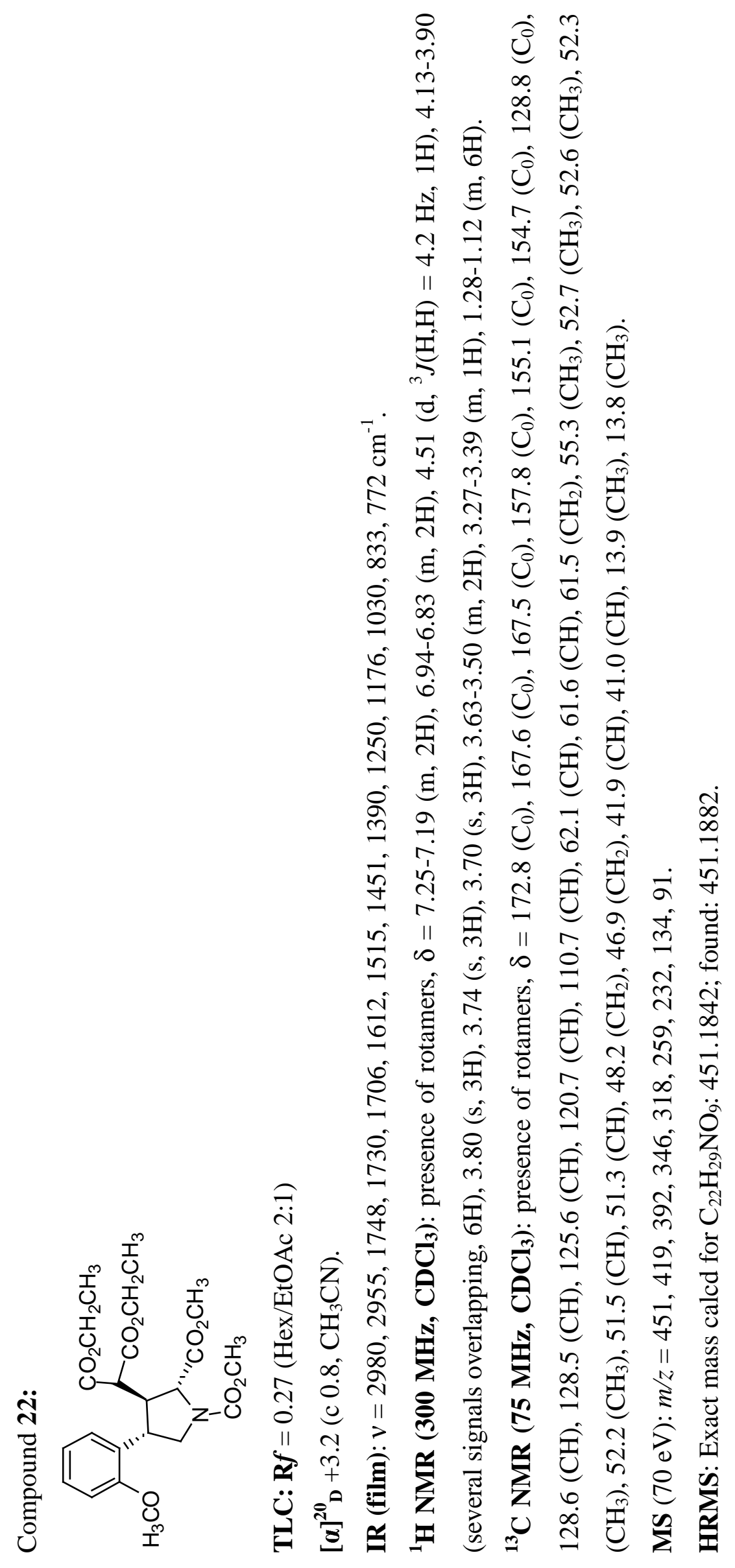




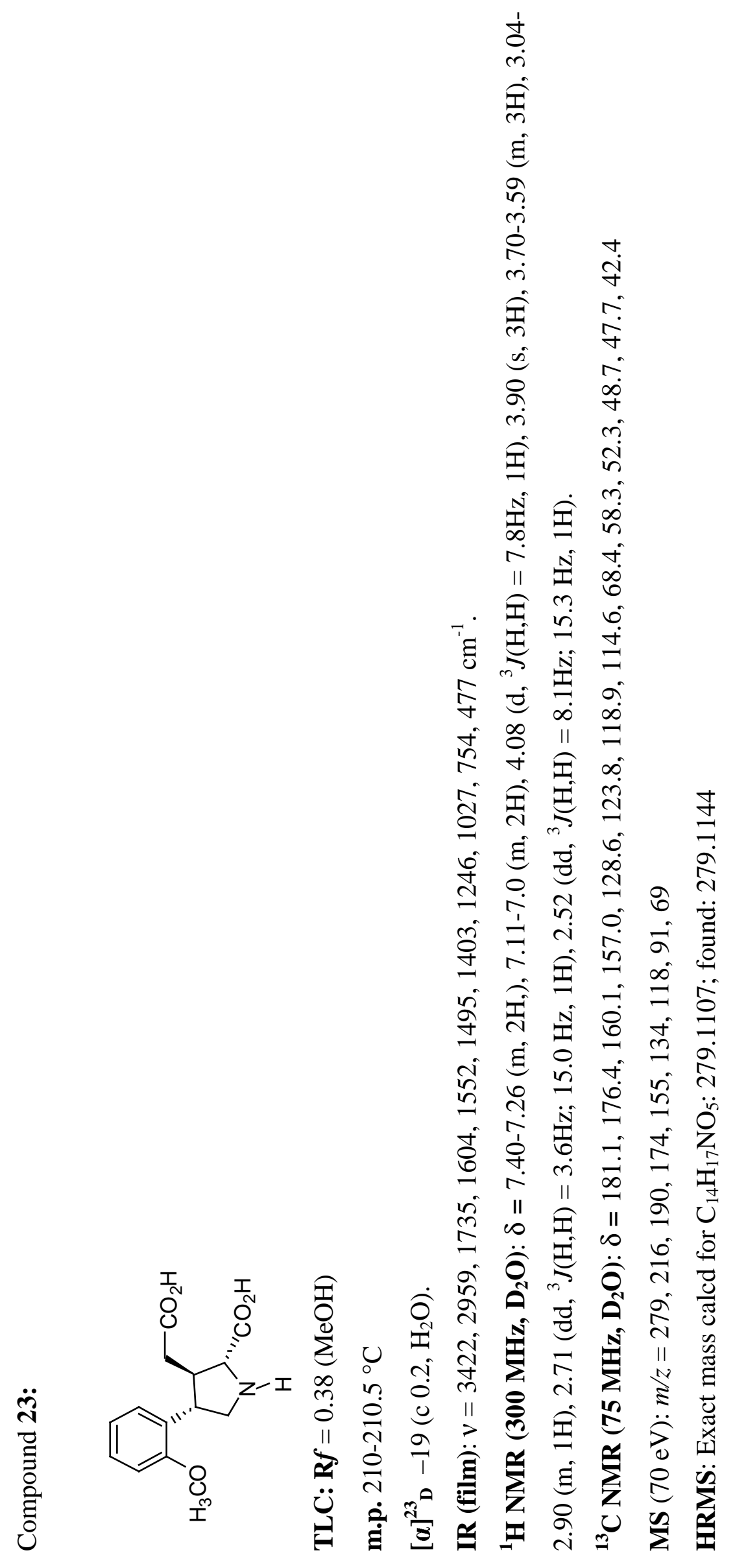




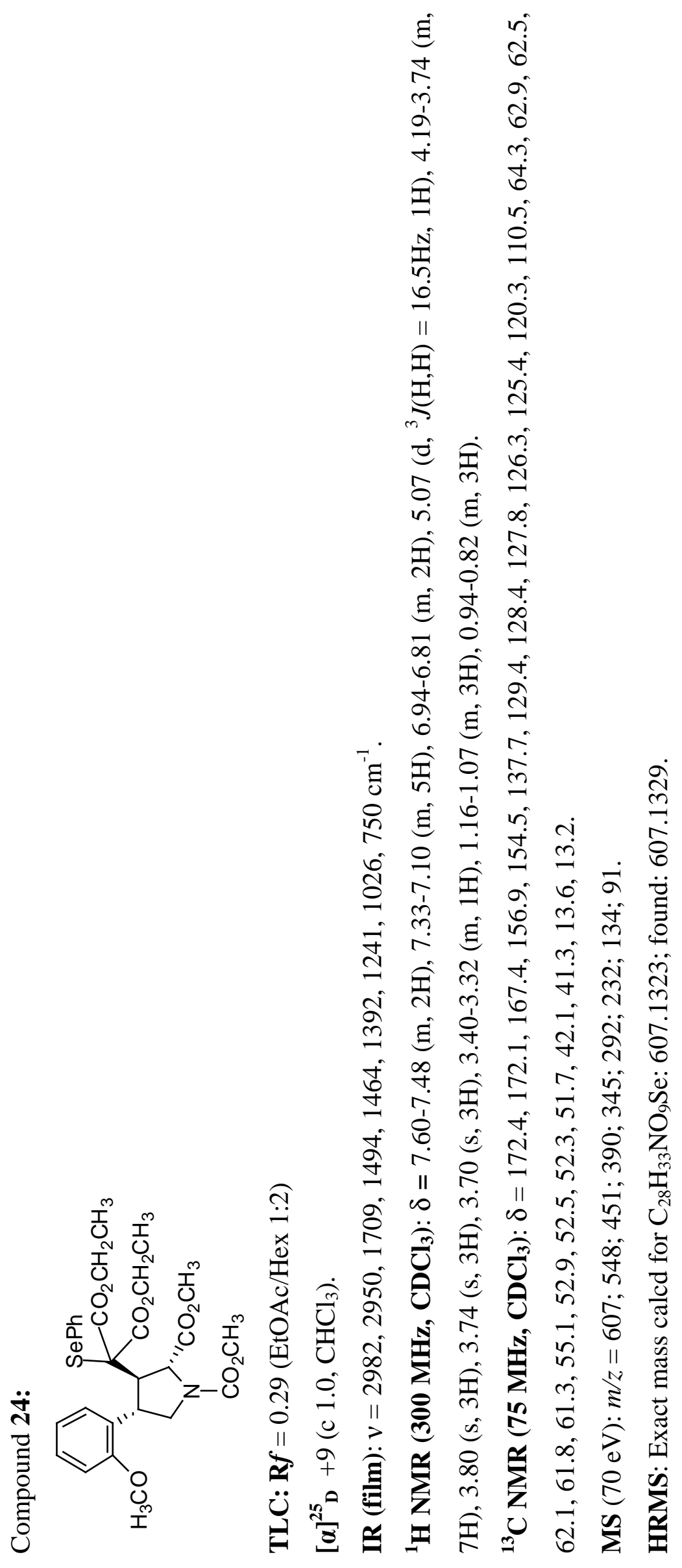




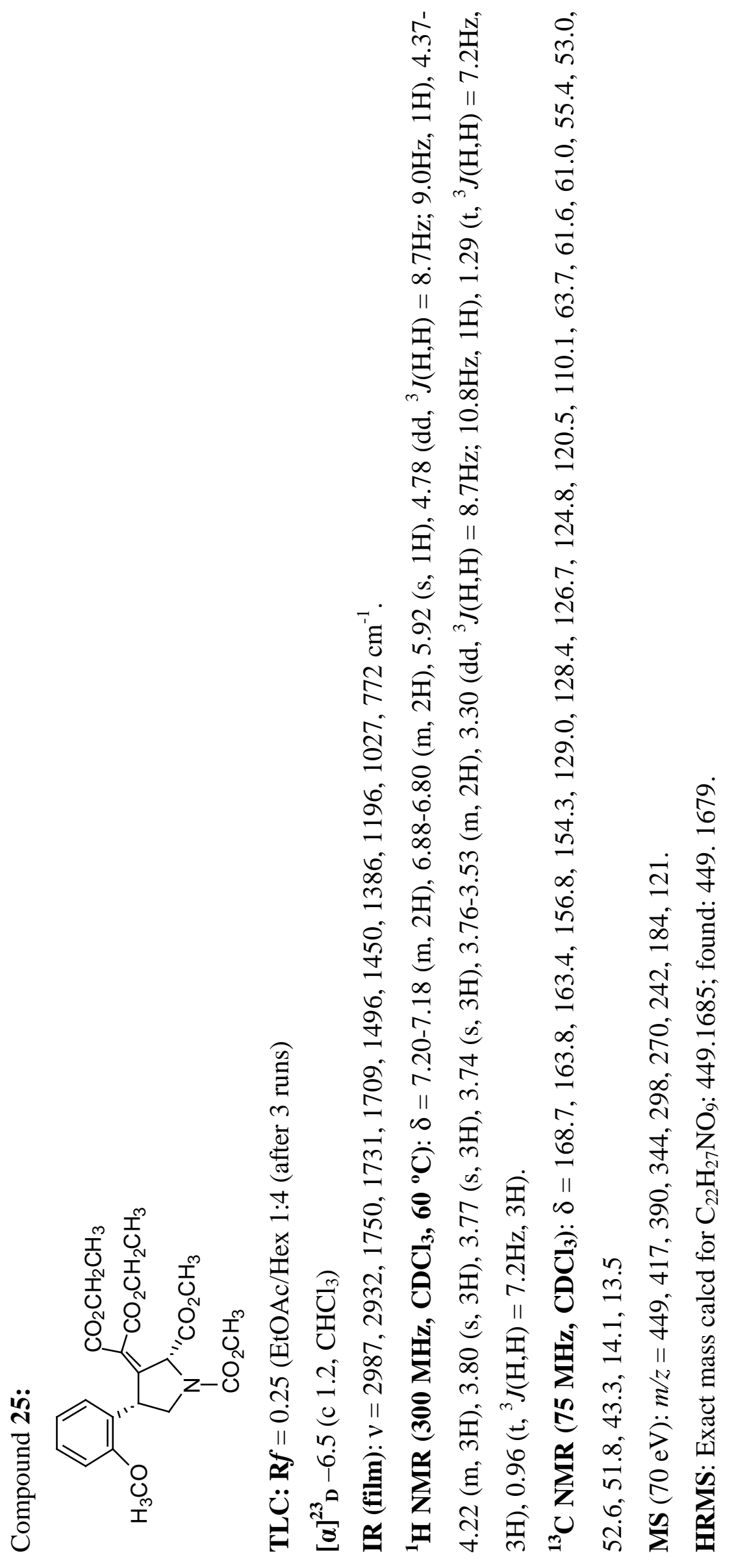



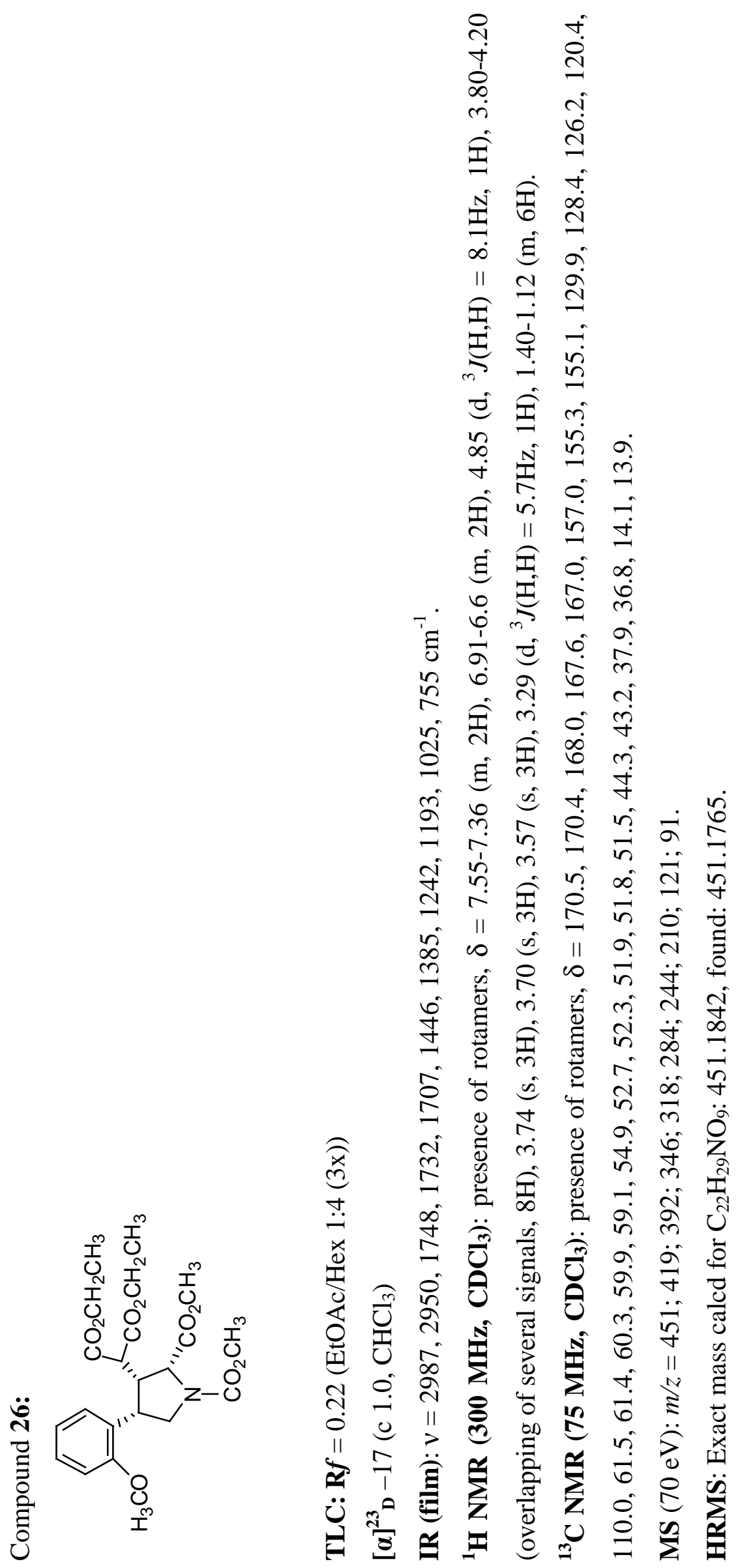


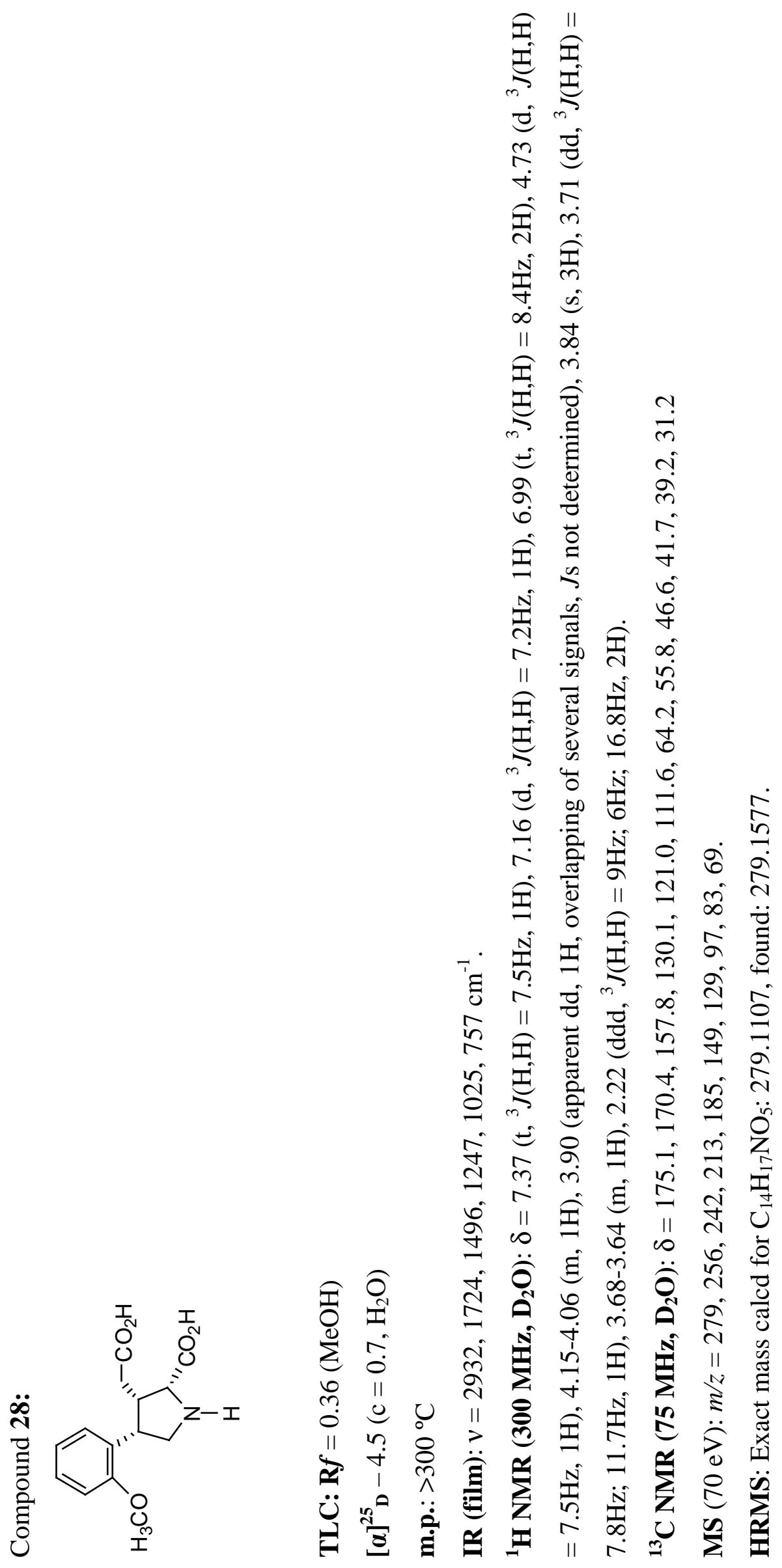




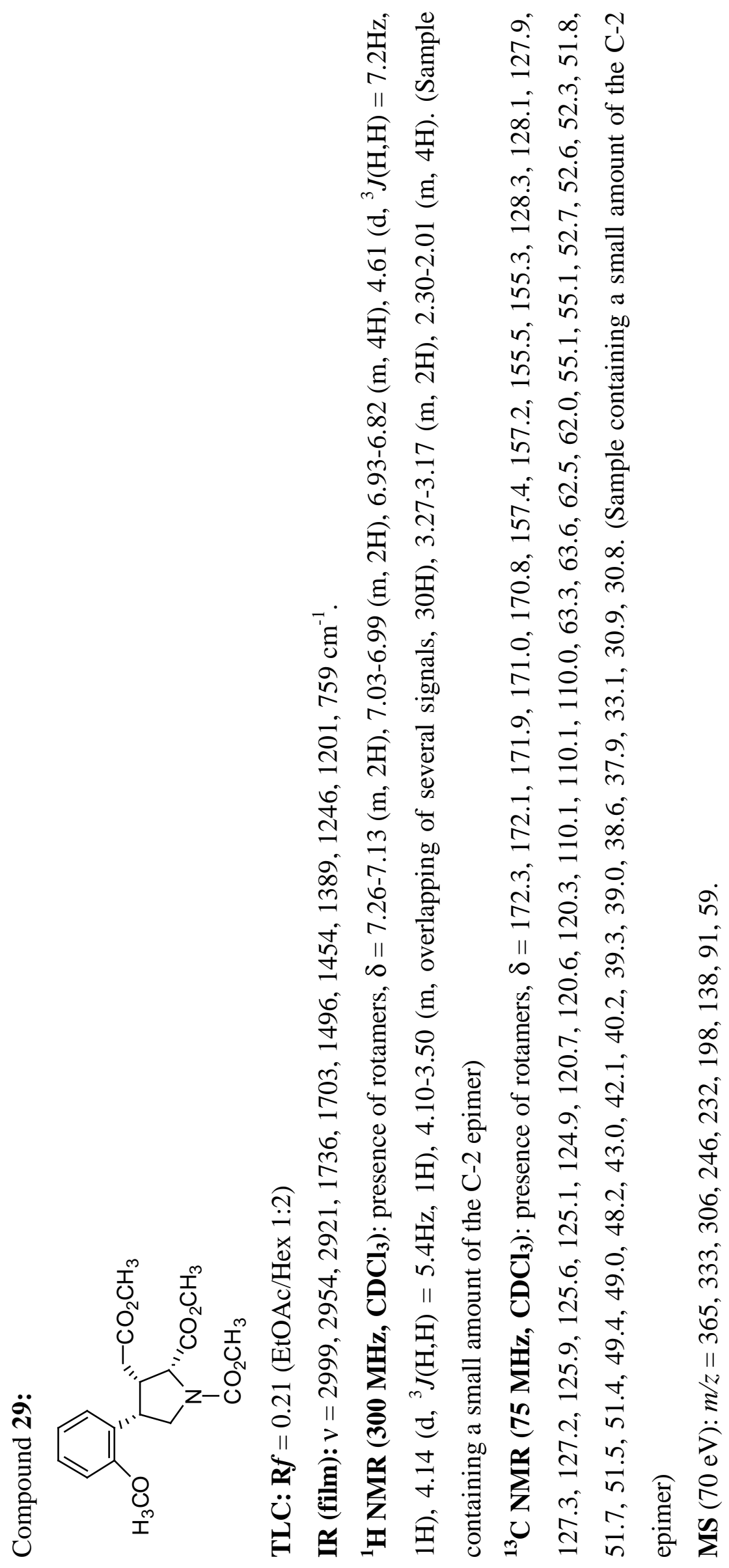




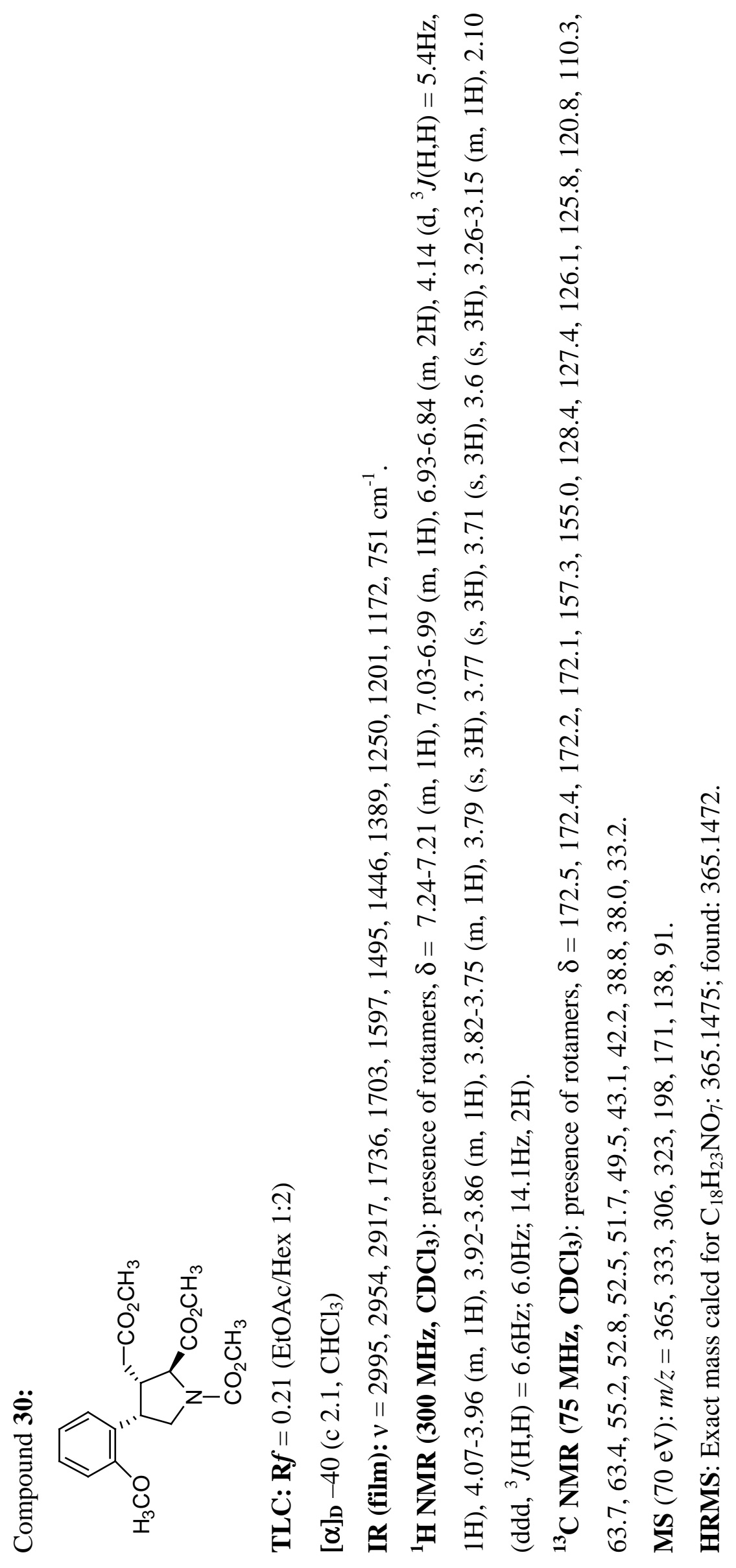




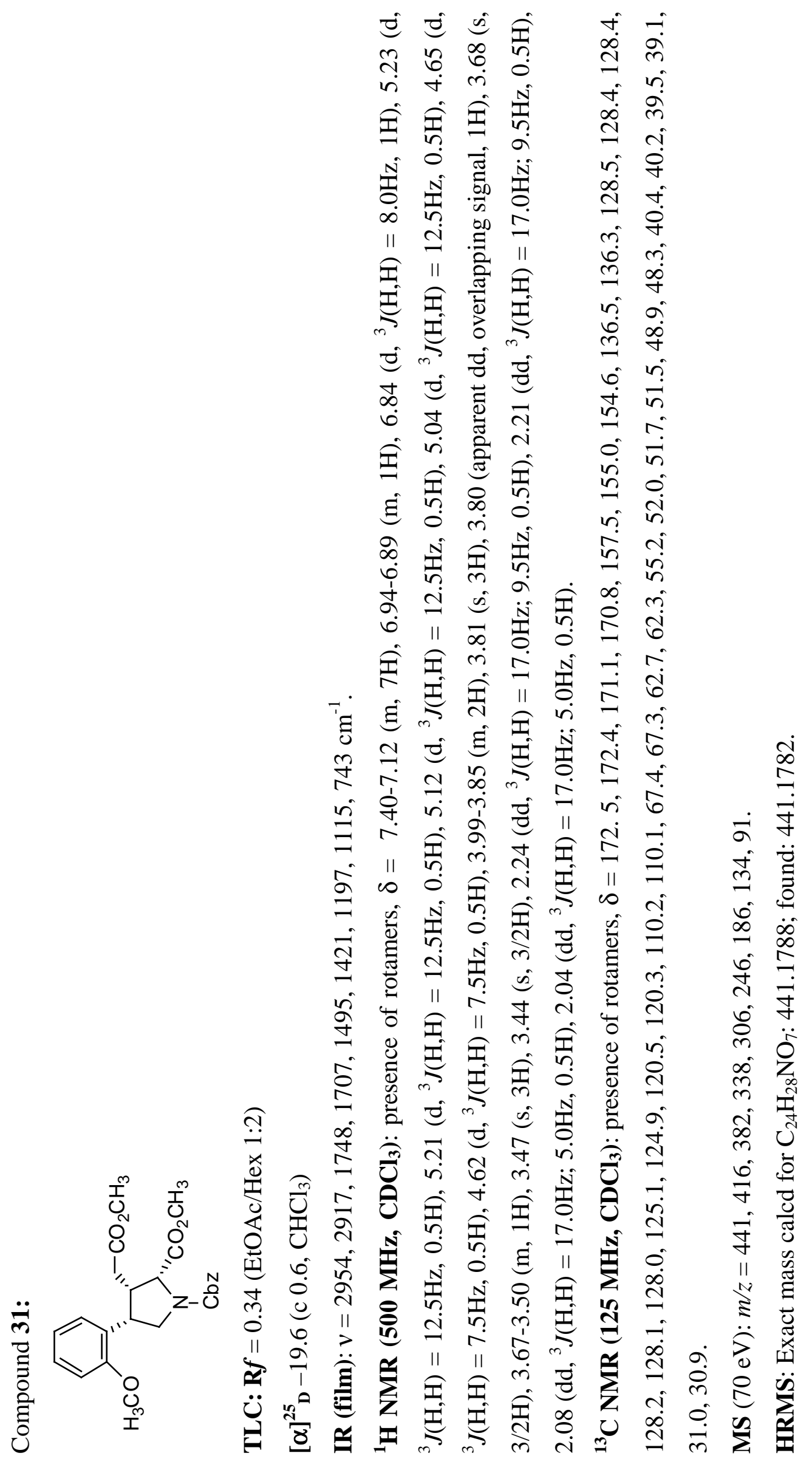




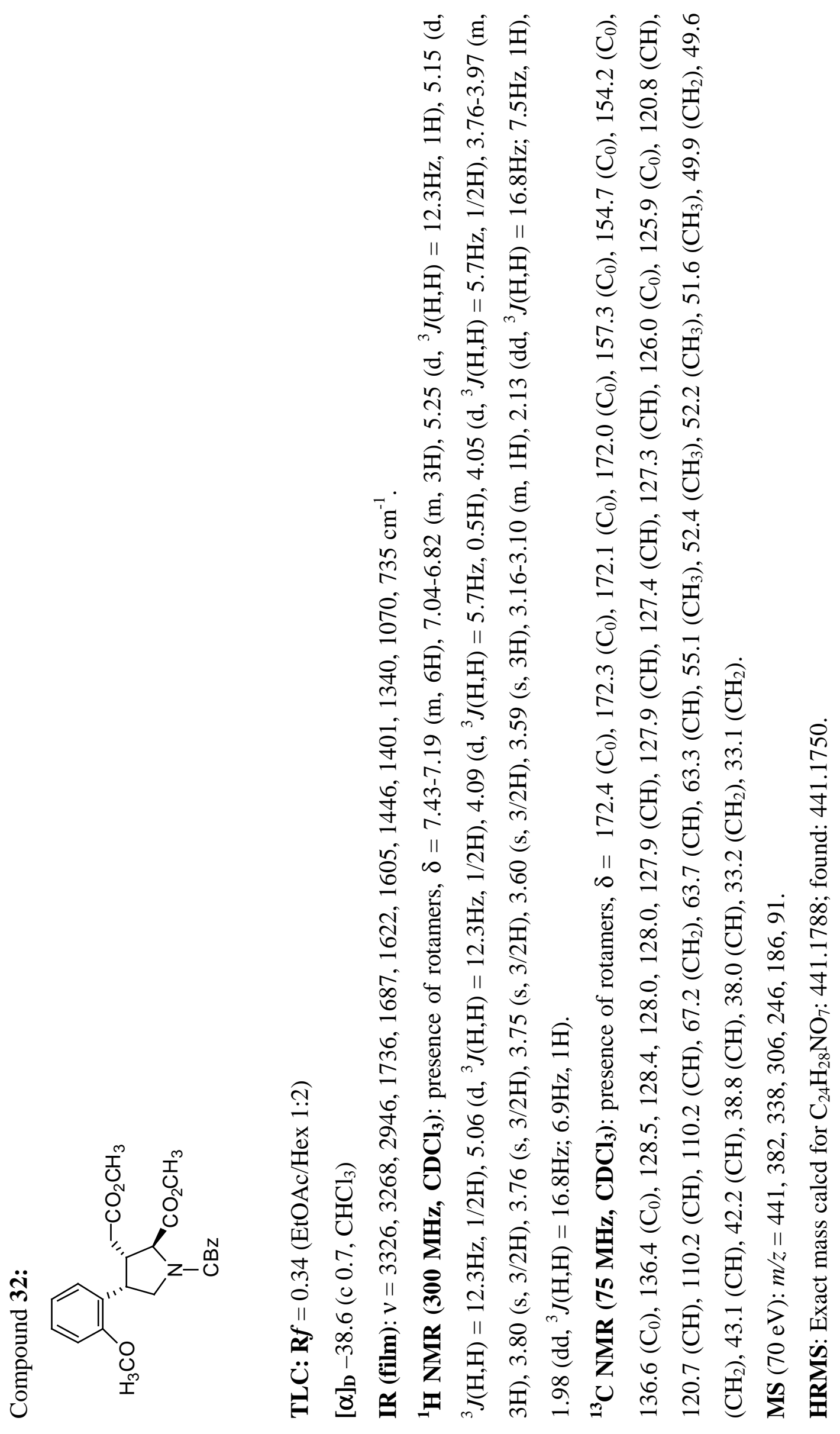




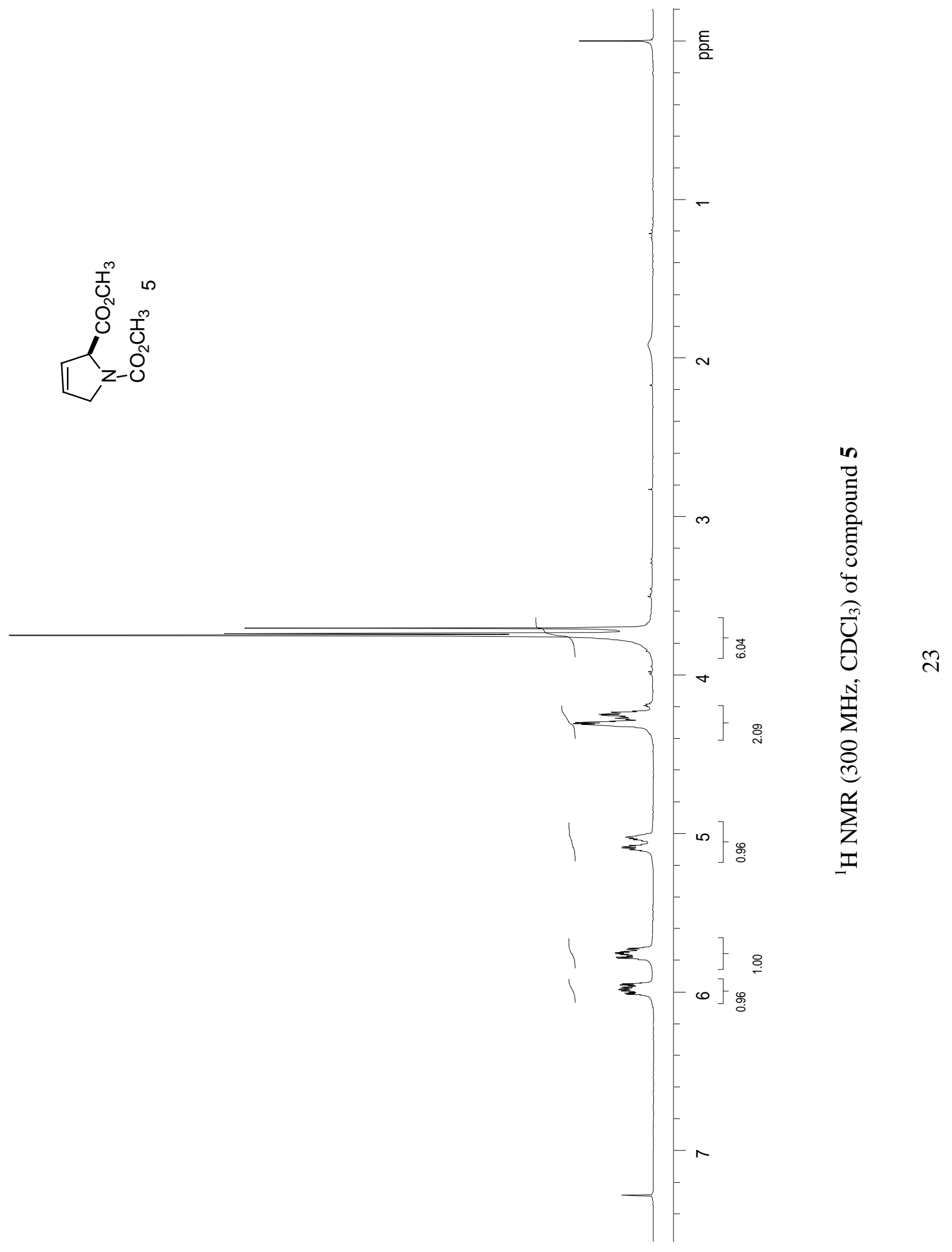



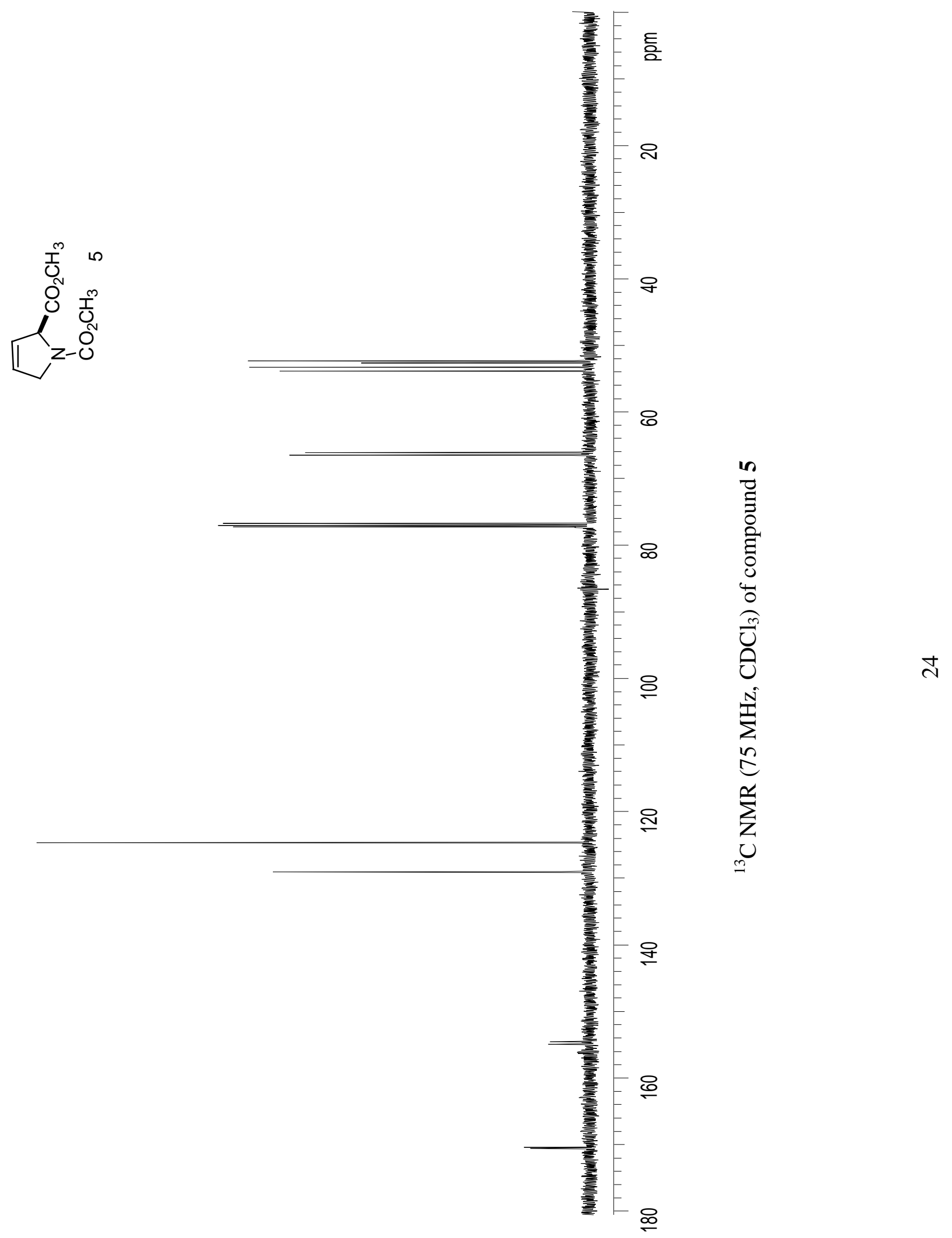


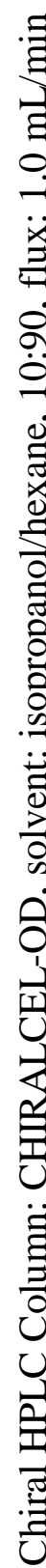

\section{IHNGIS dO GNJ}

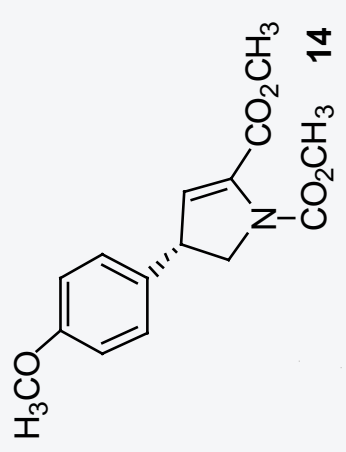




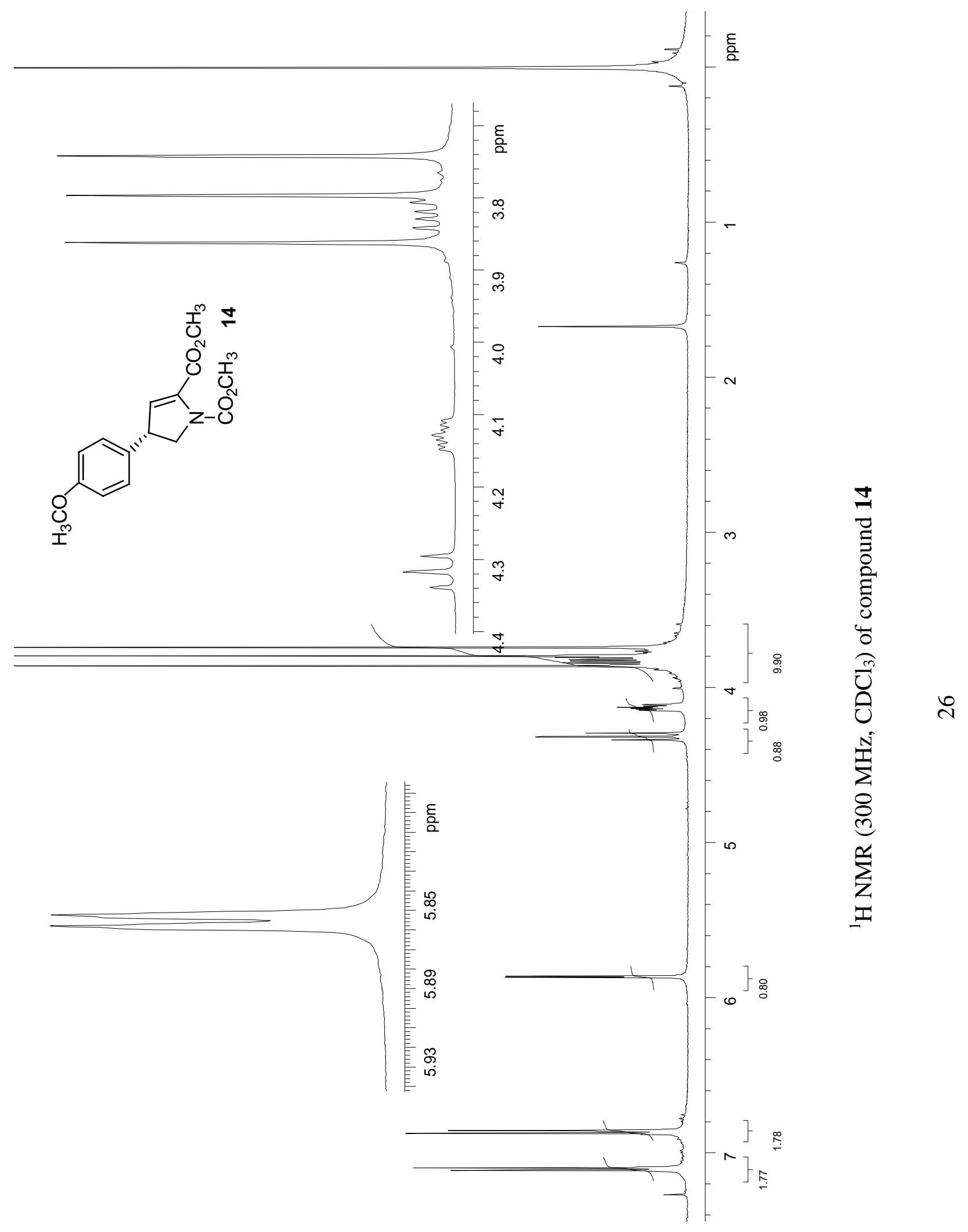




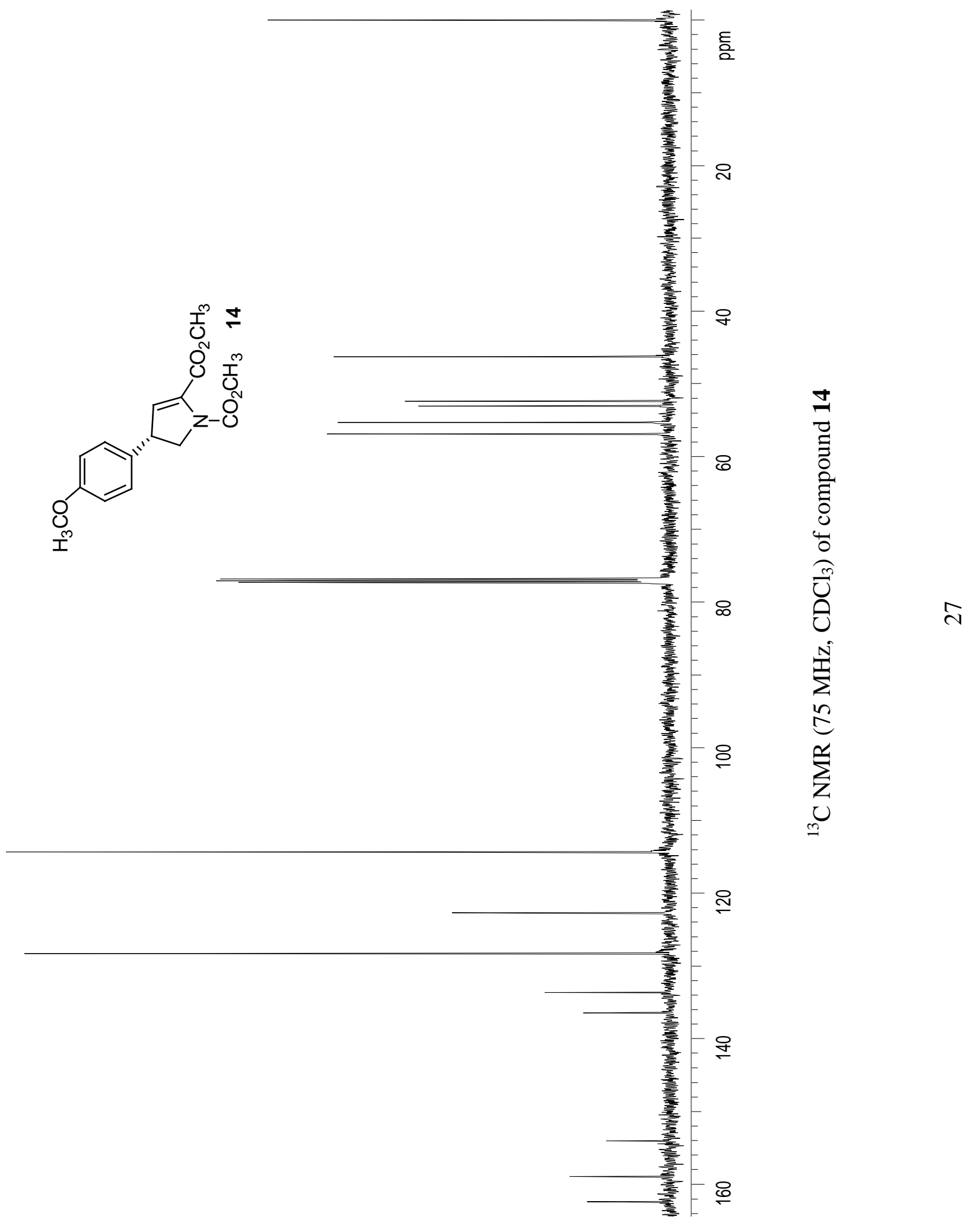



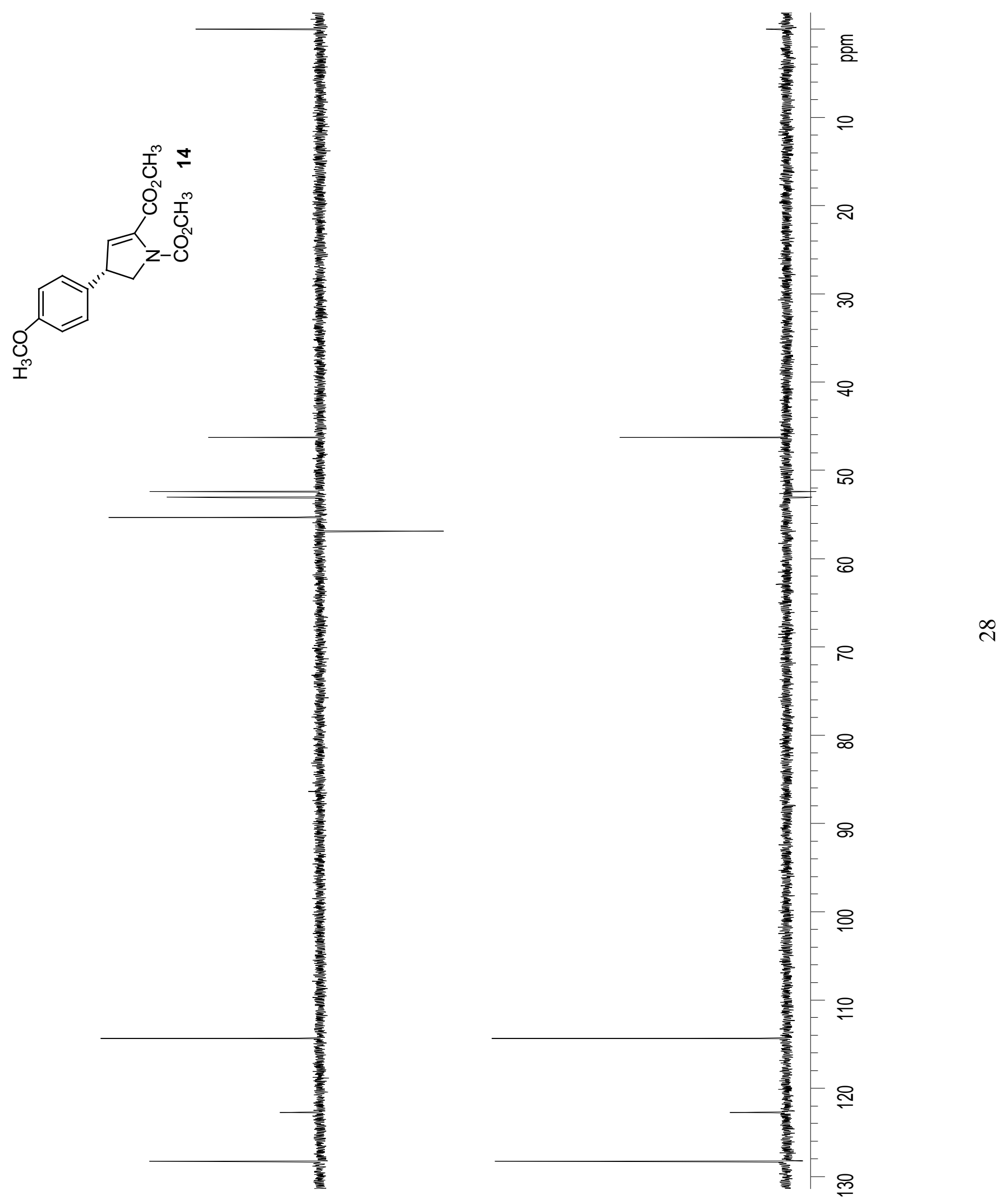


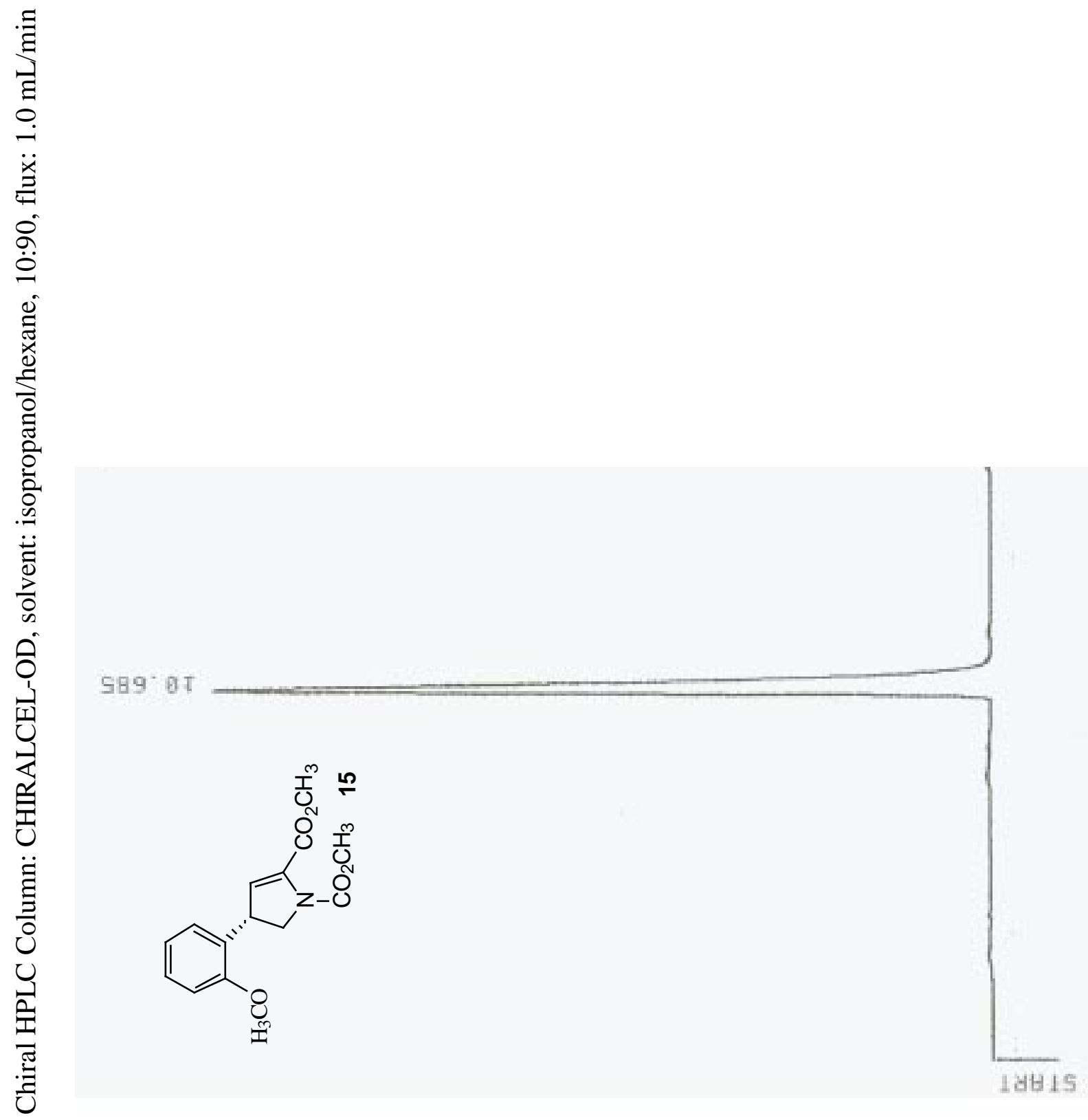




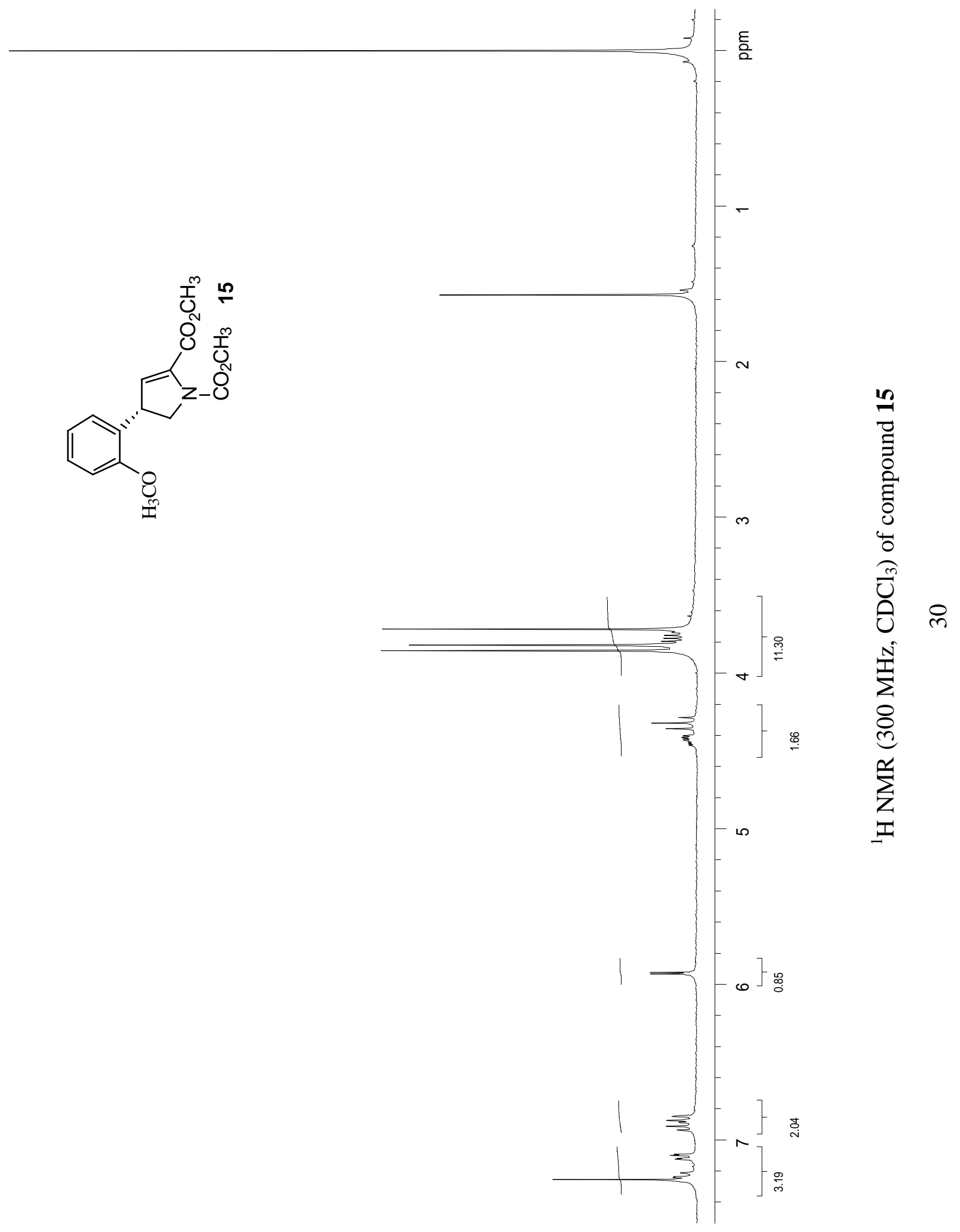



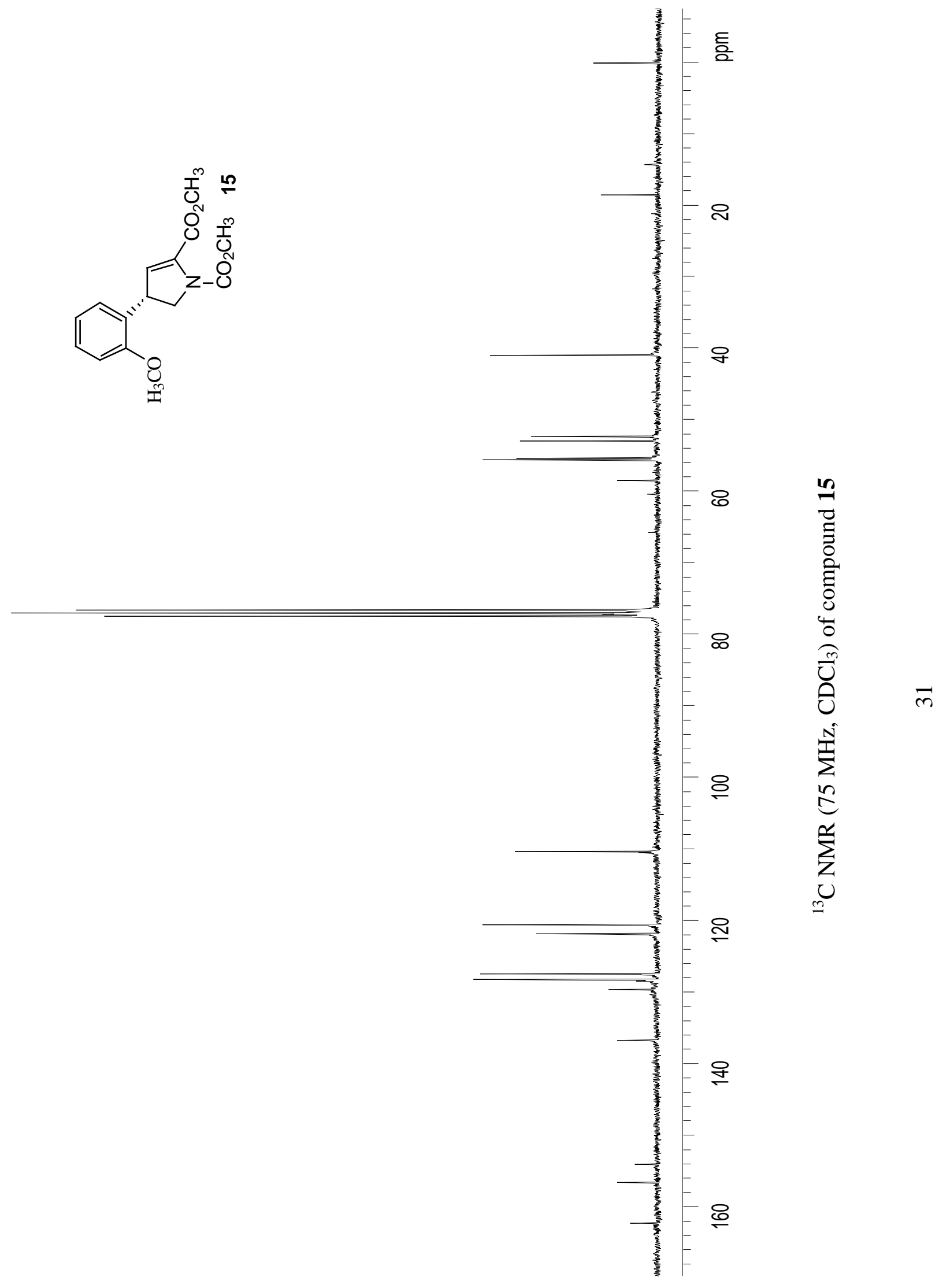


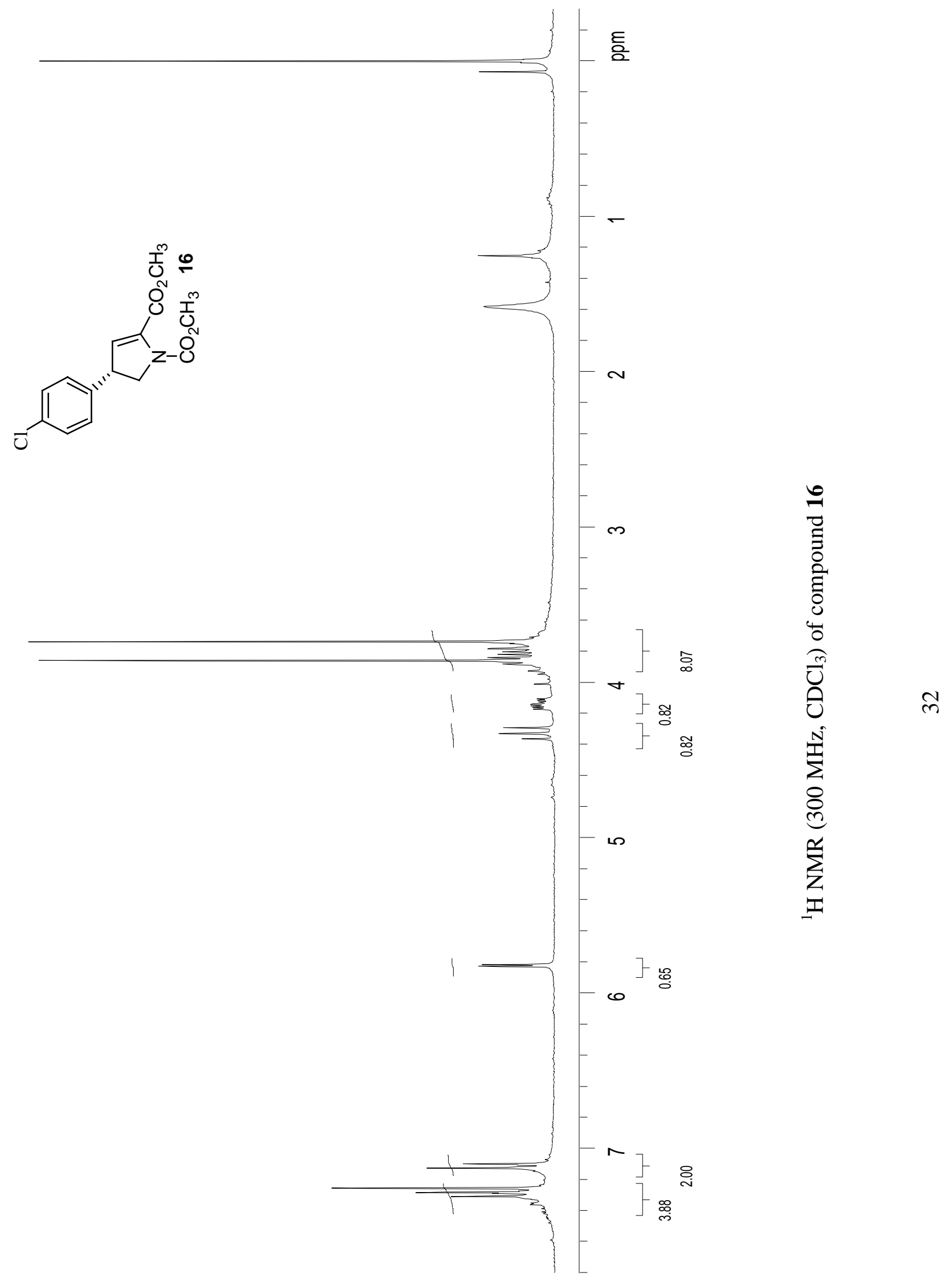



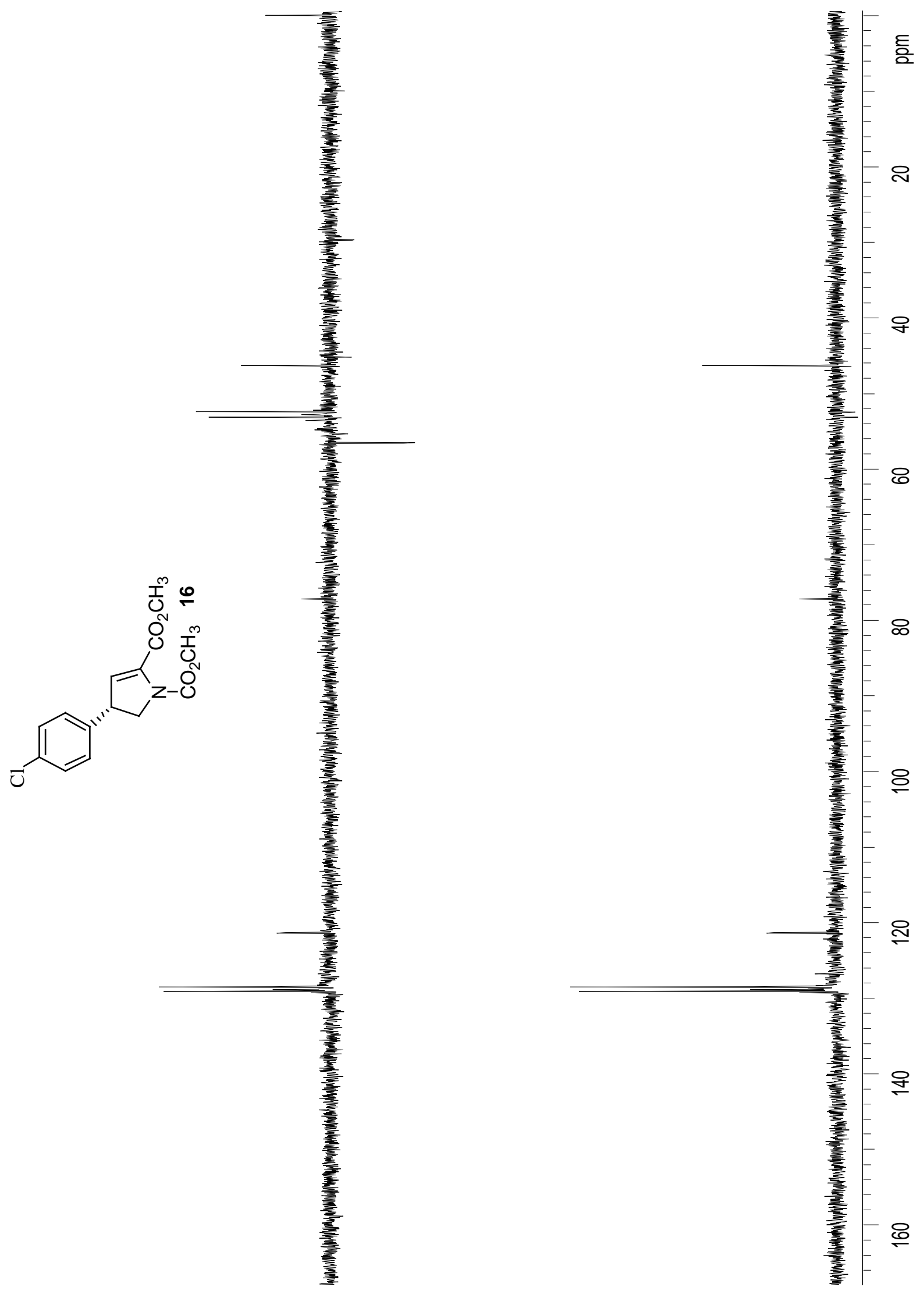


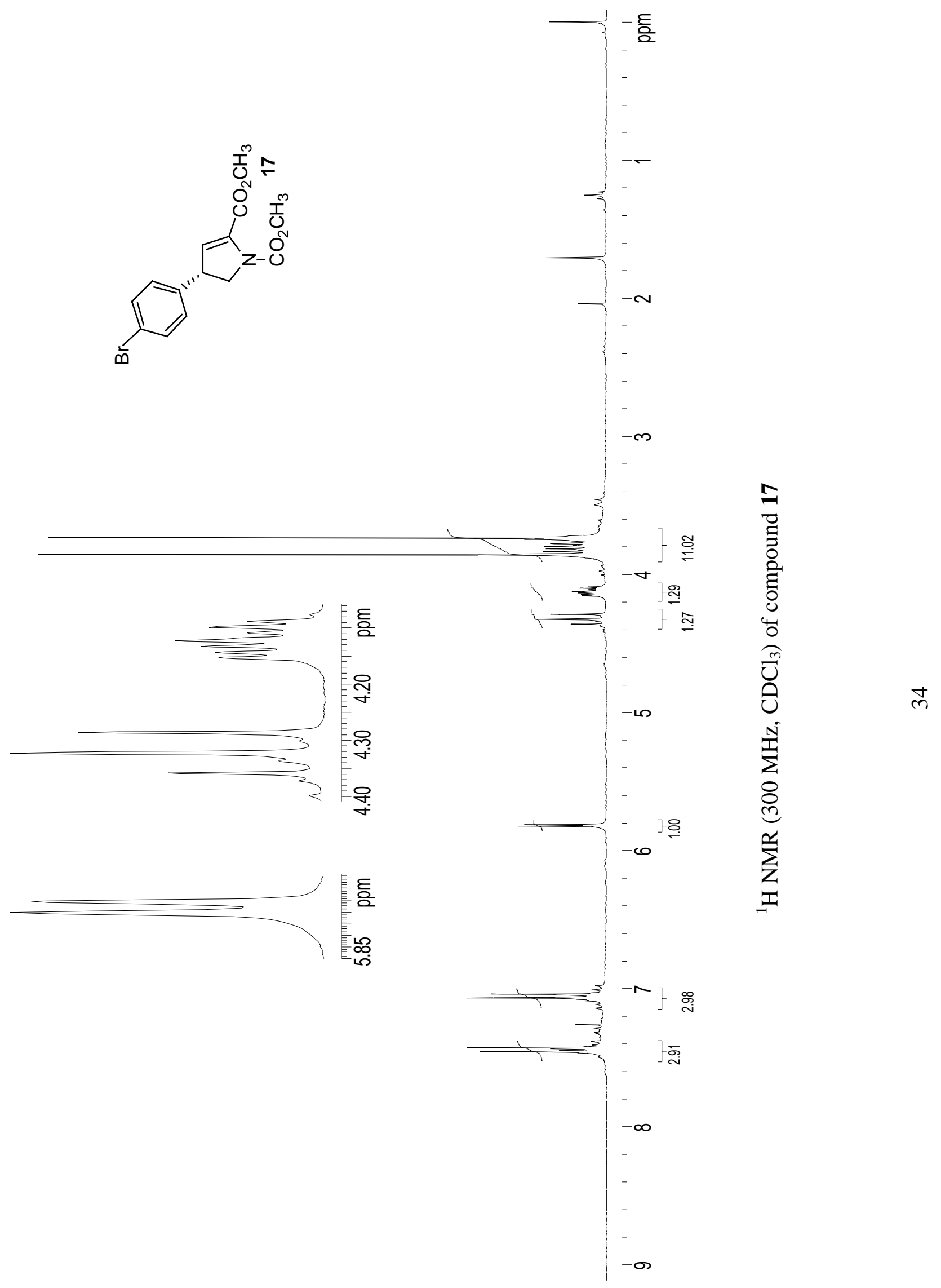




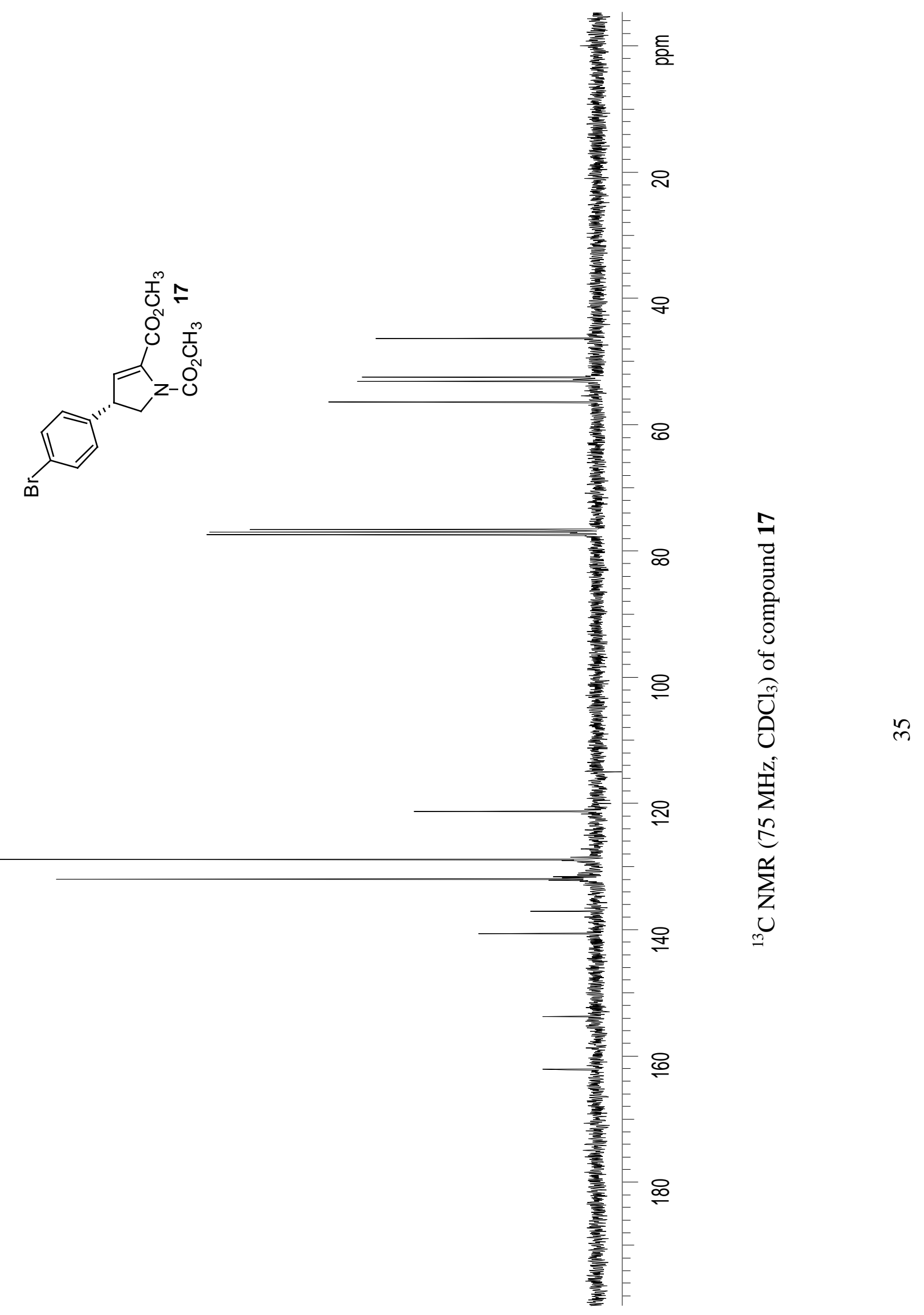




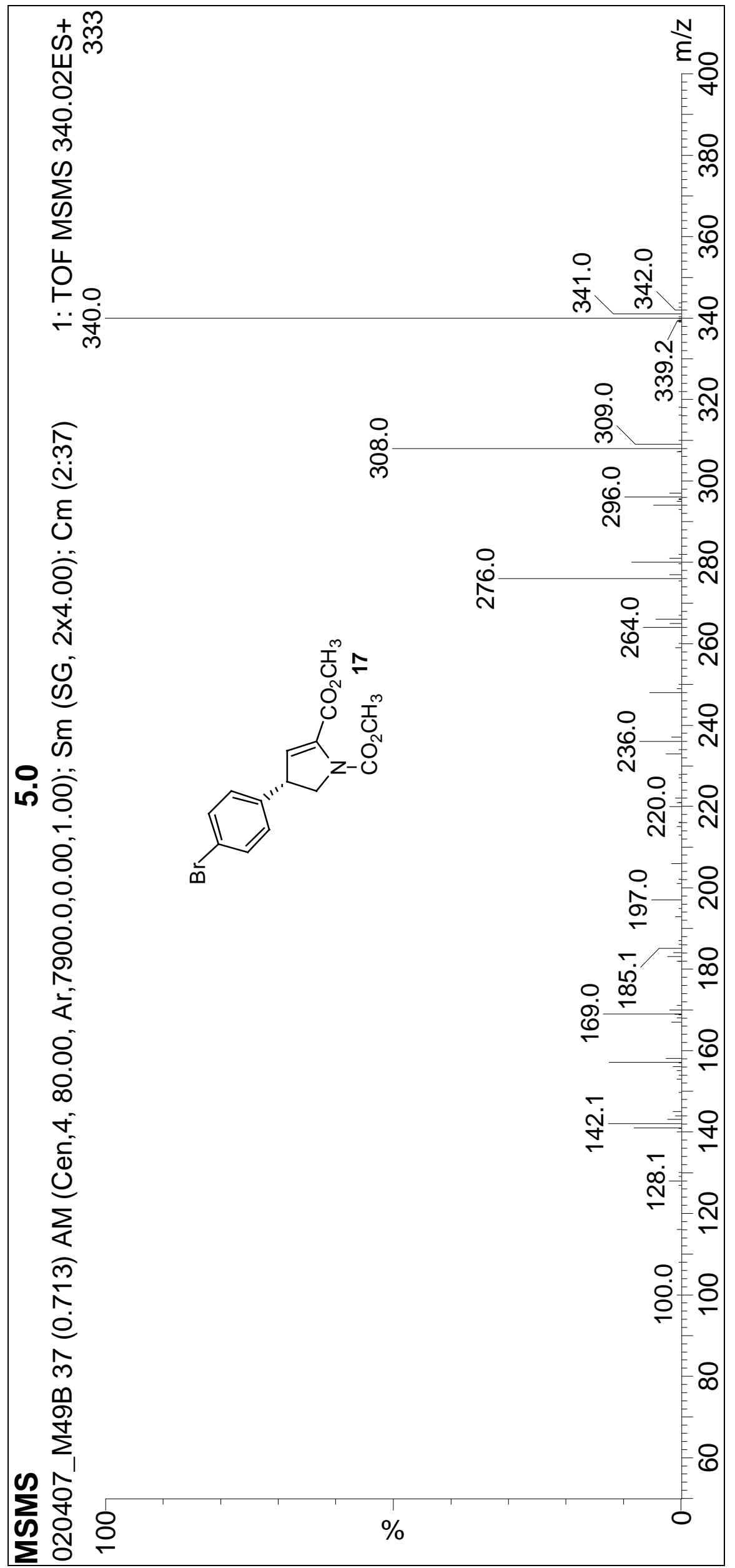




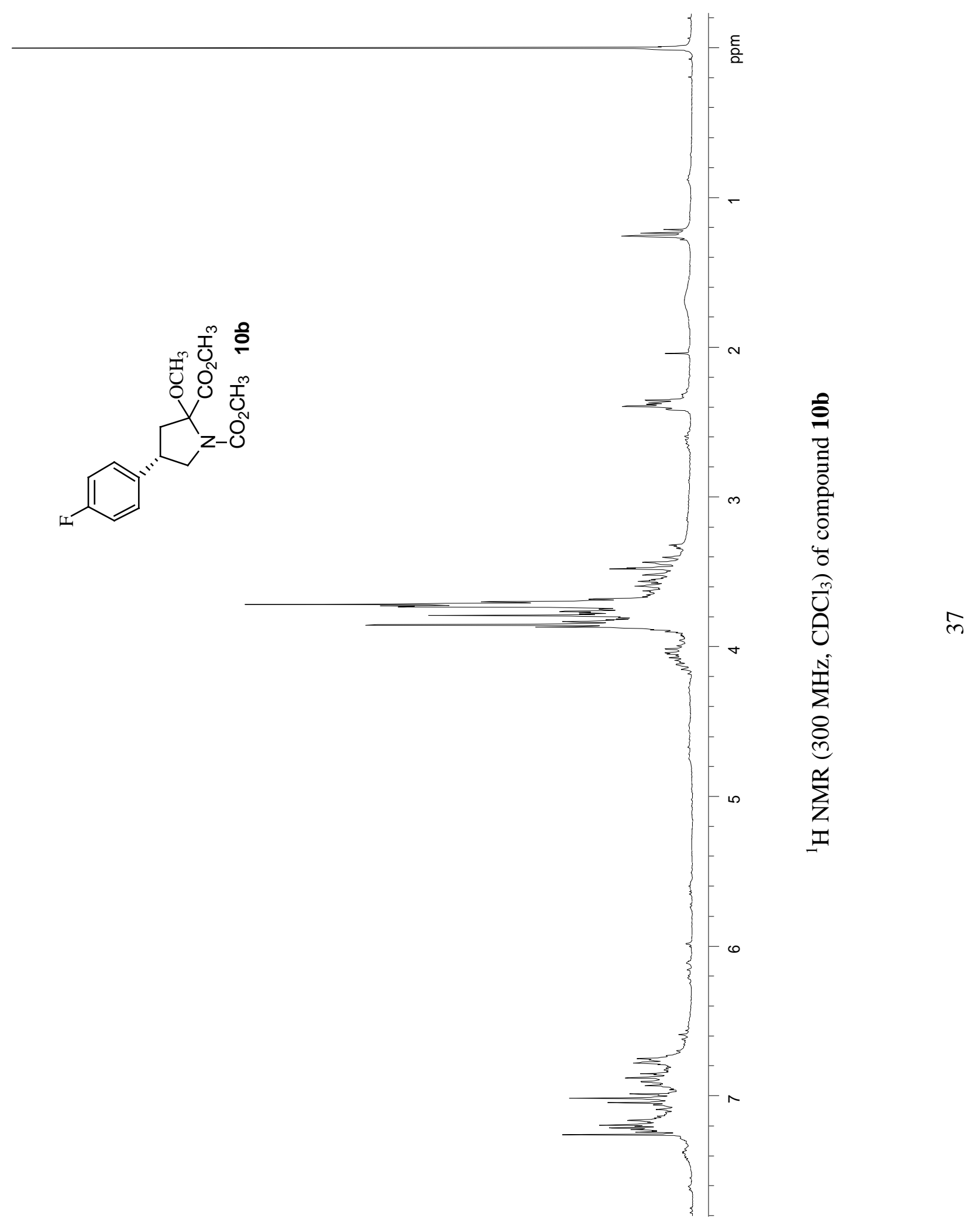




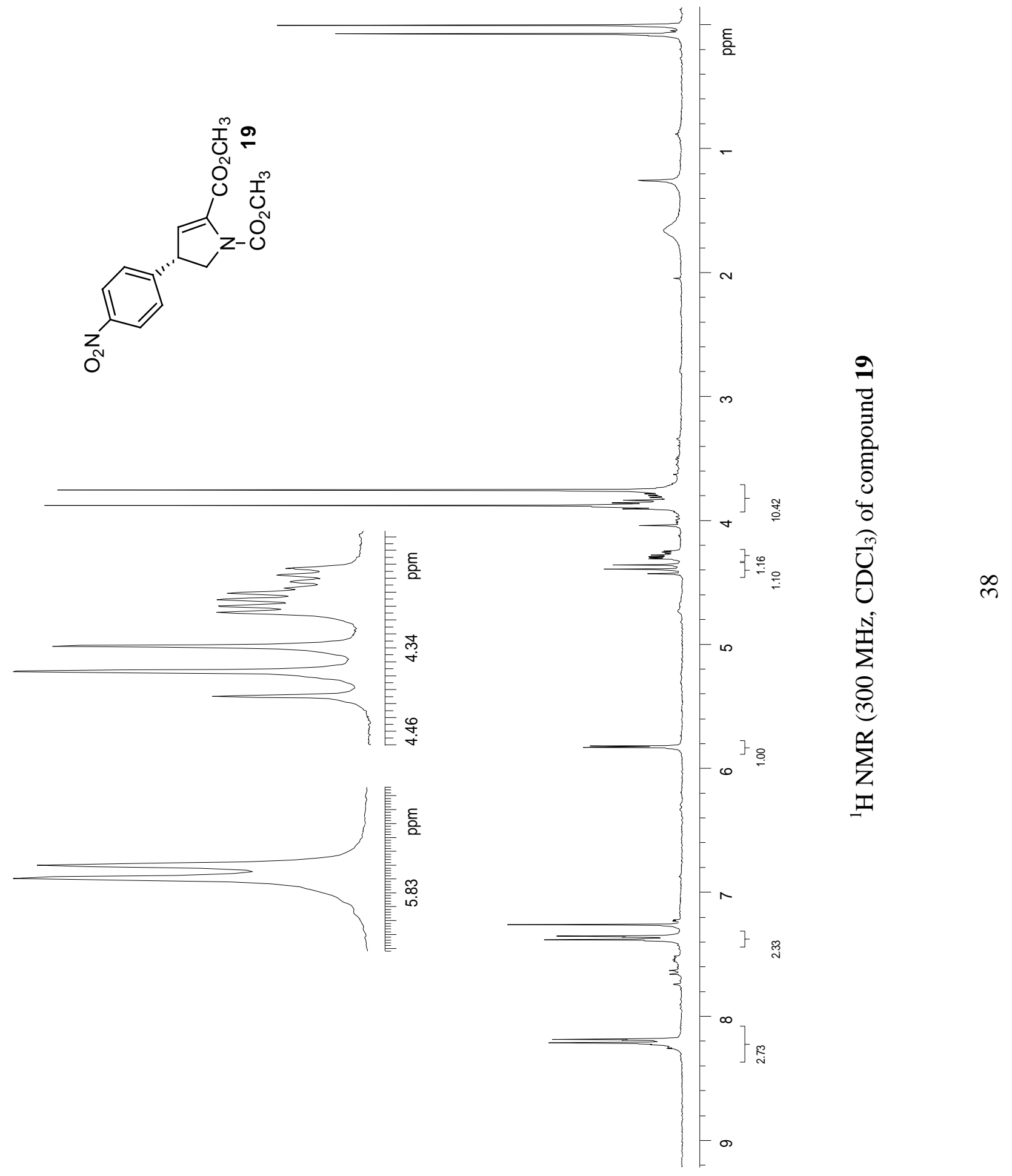




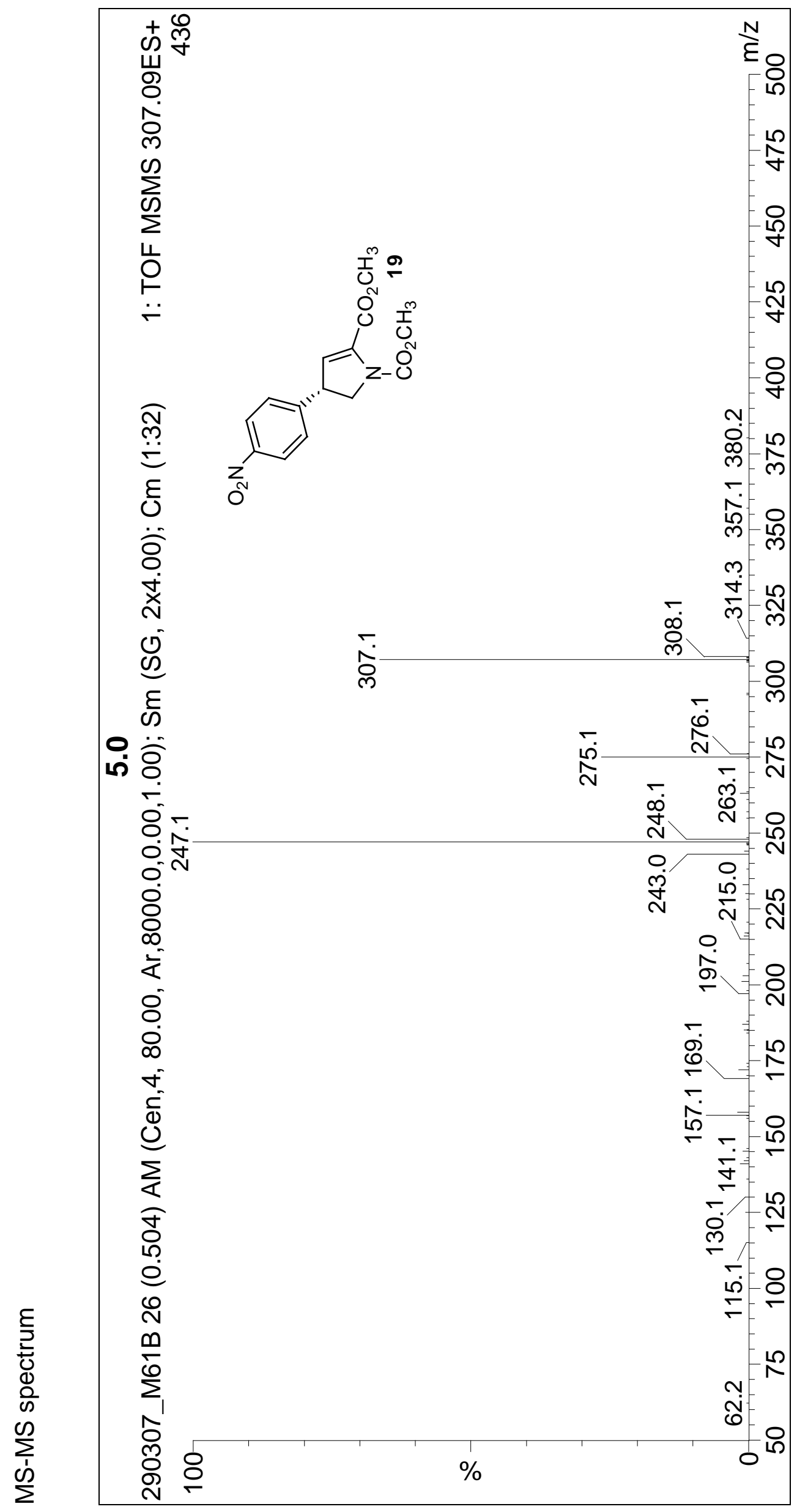




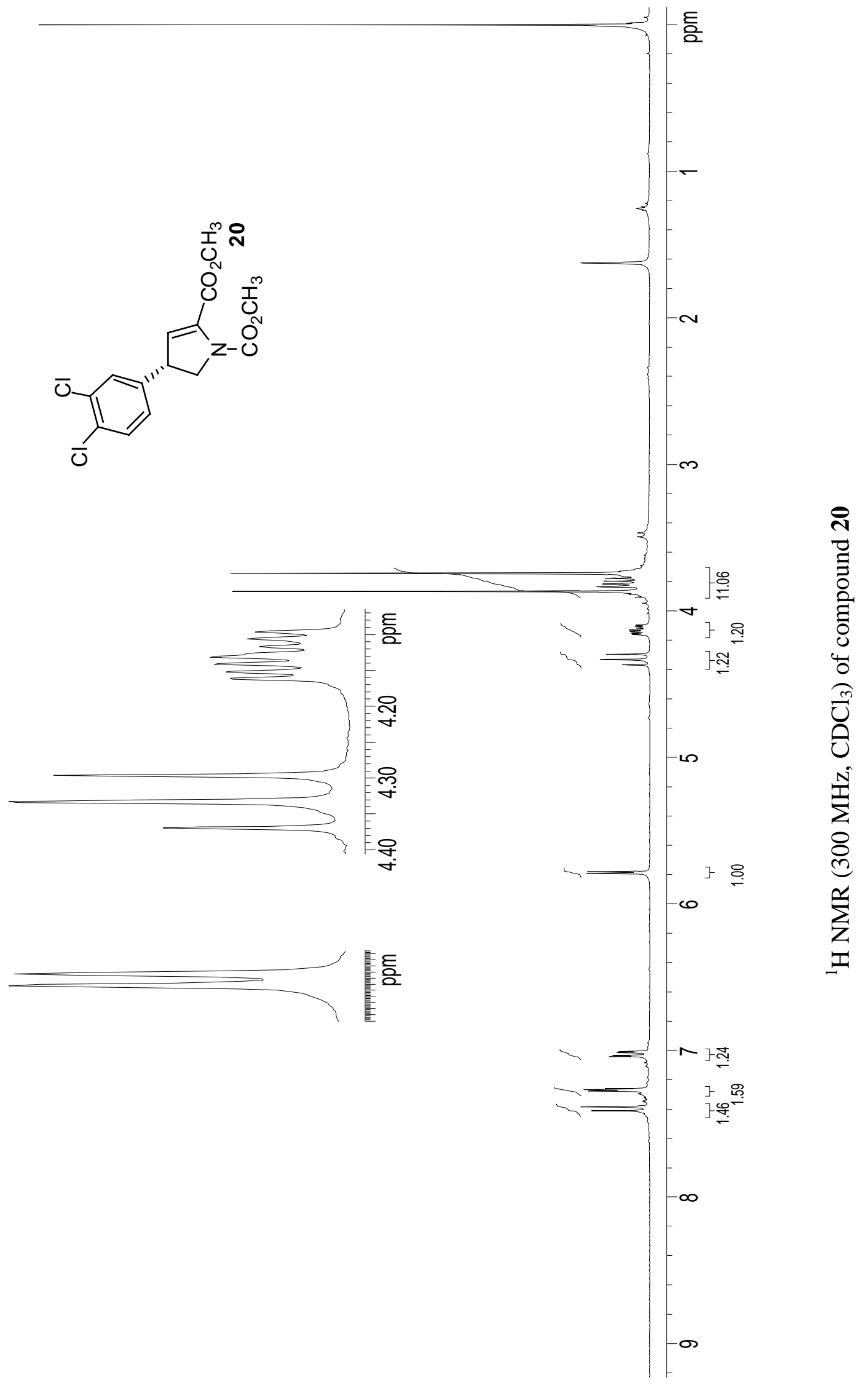




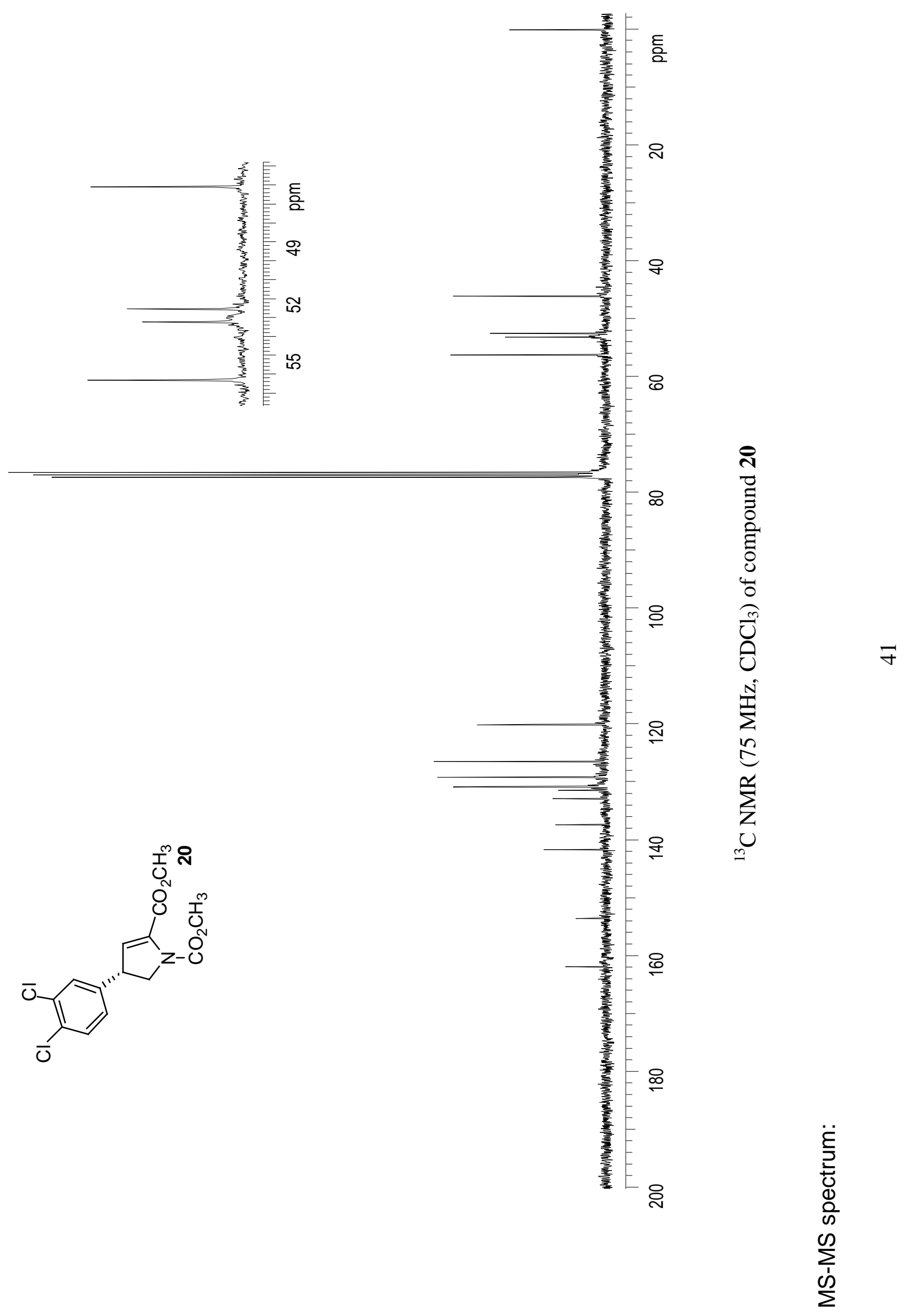




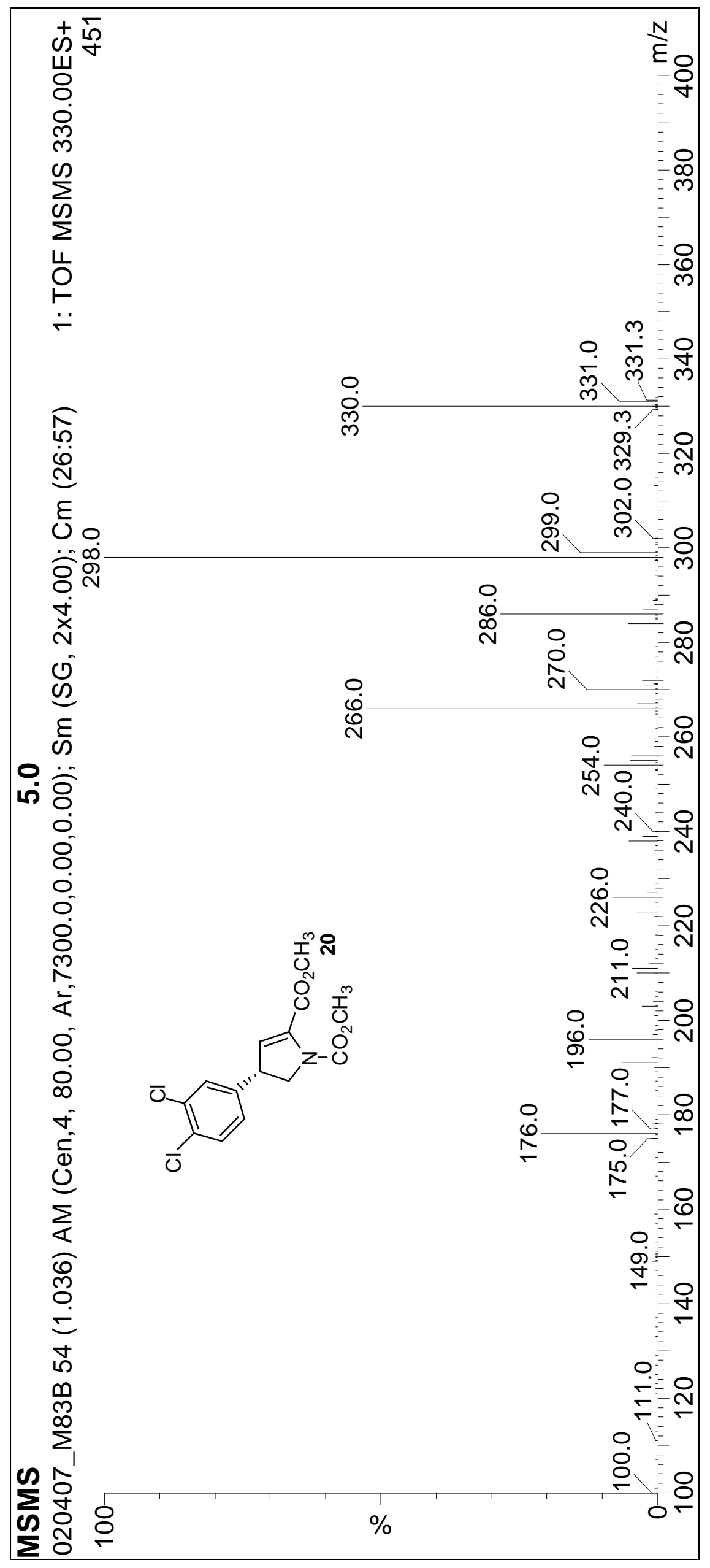




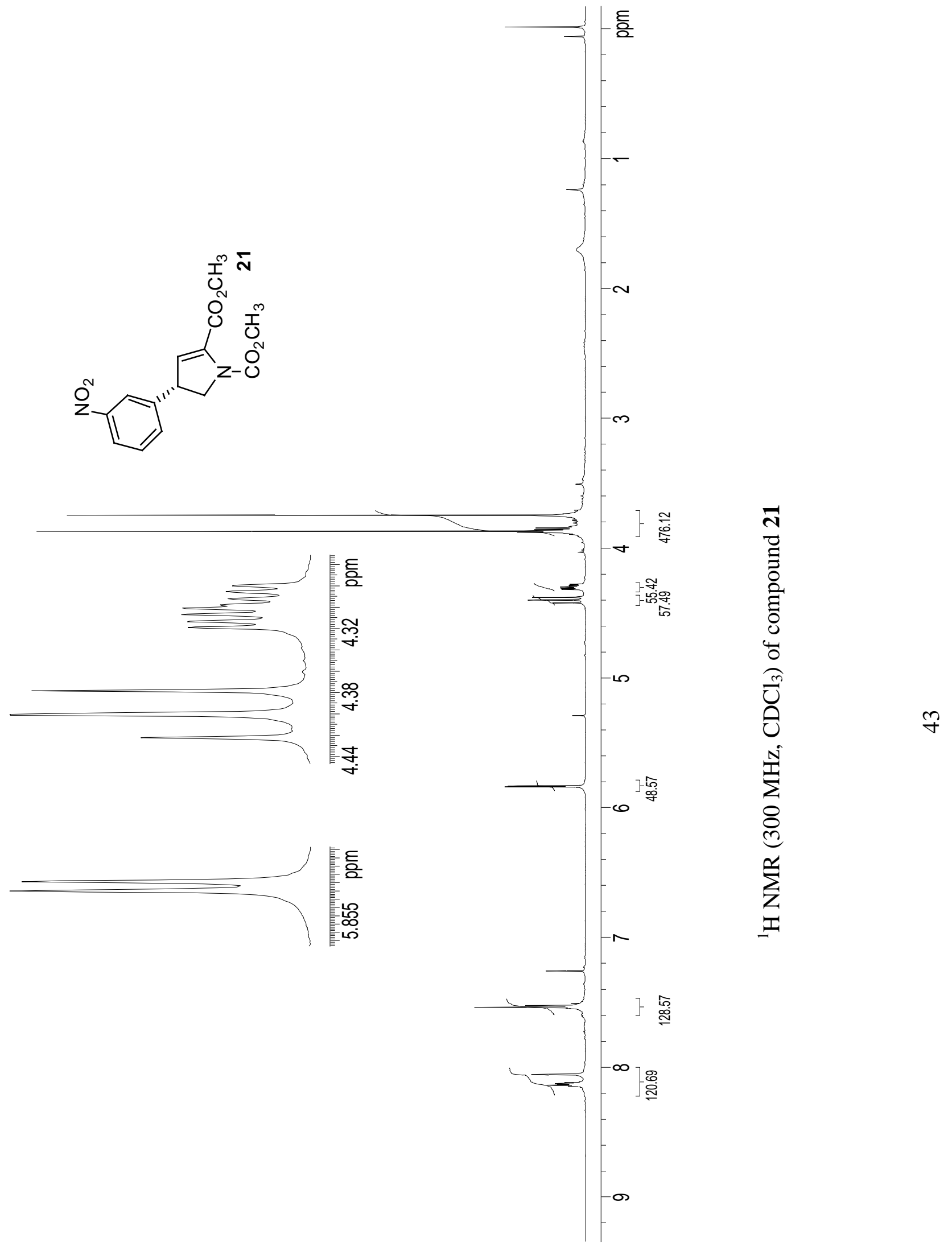




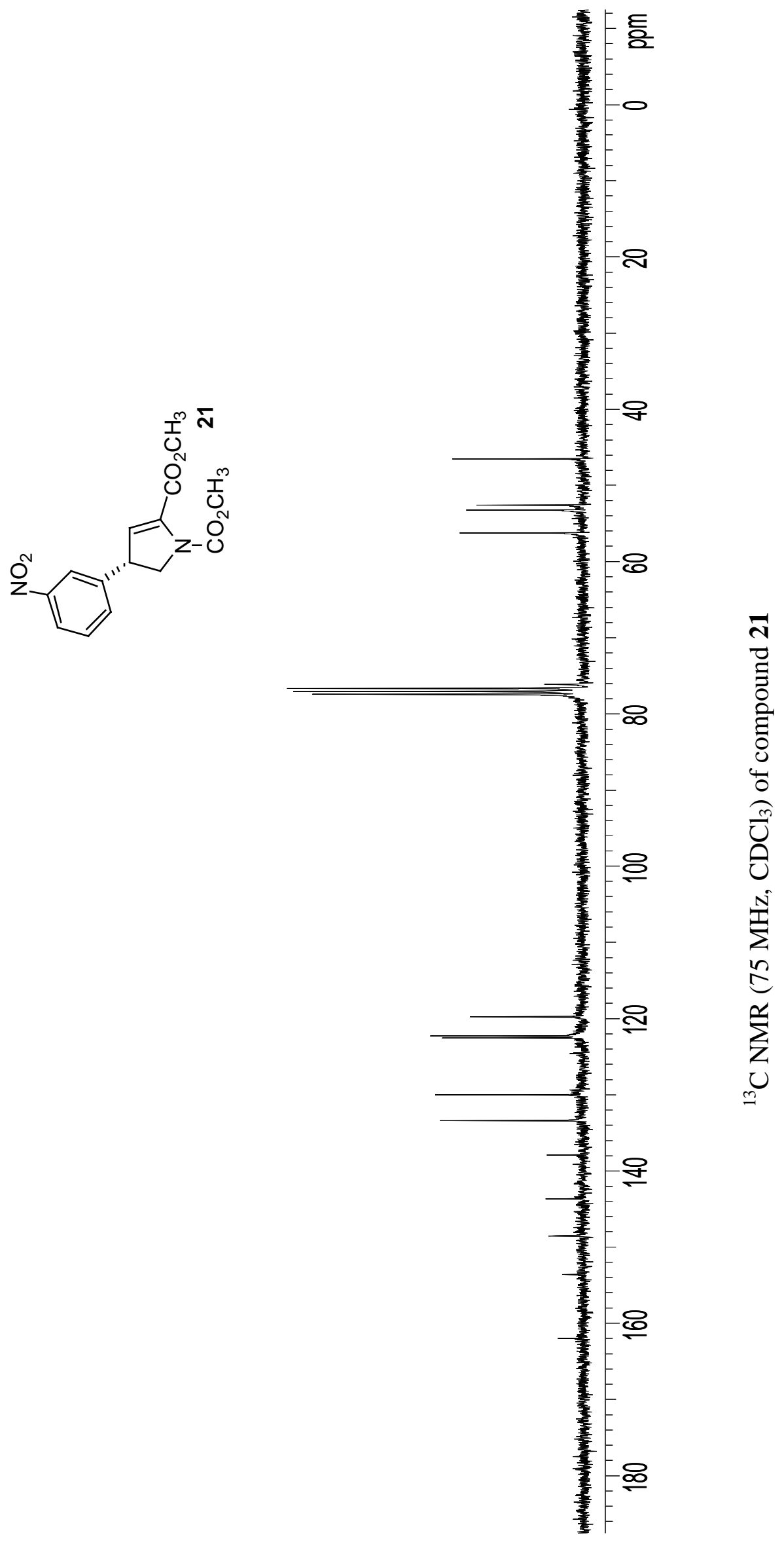




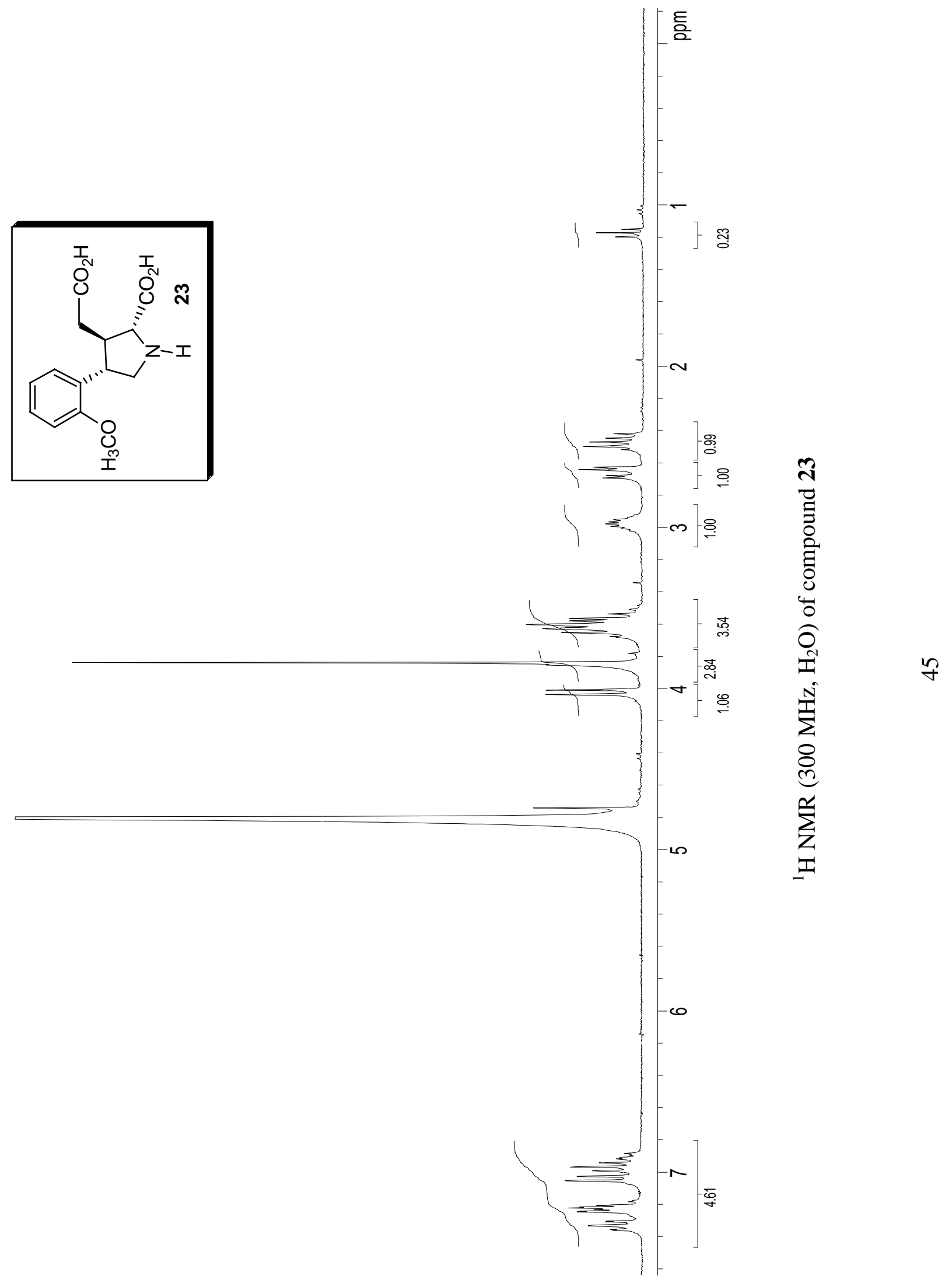




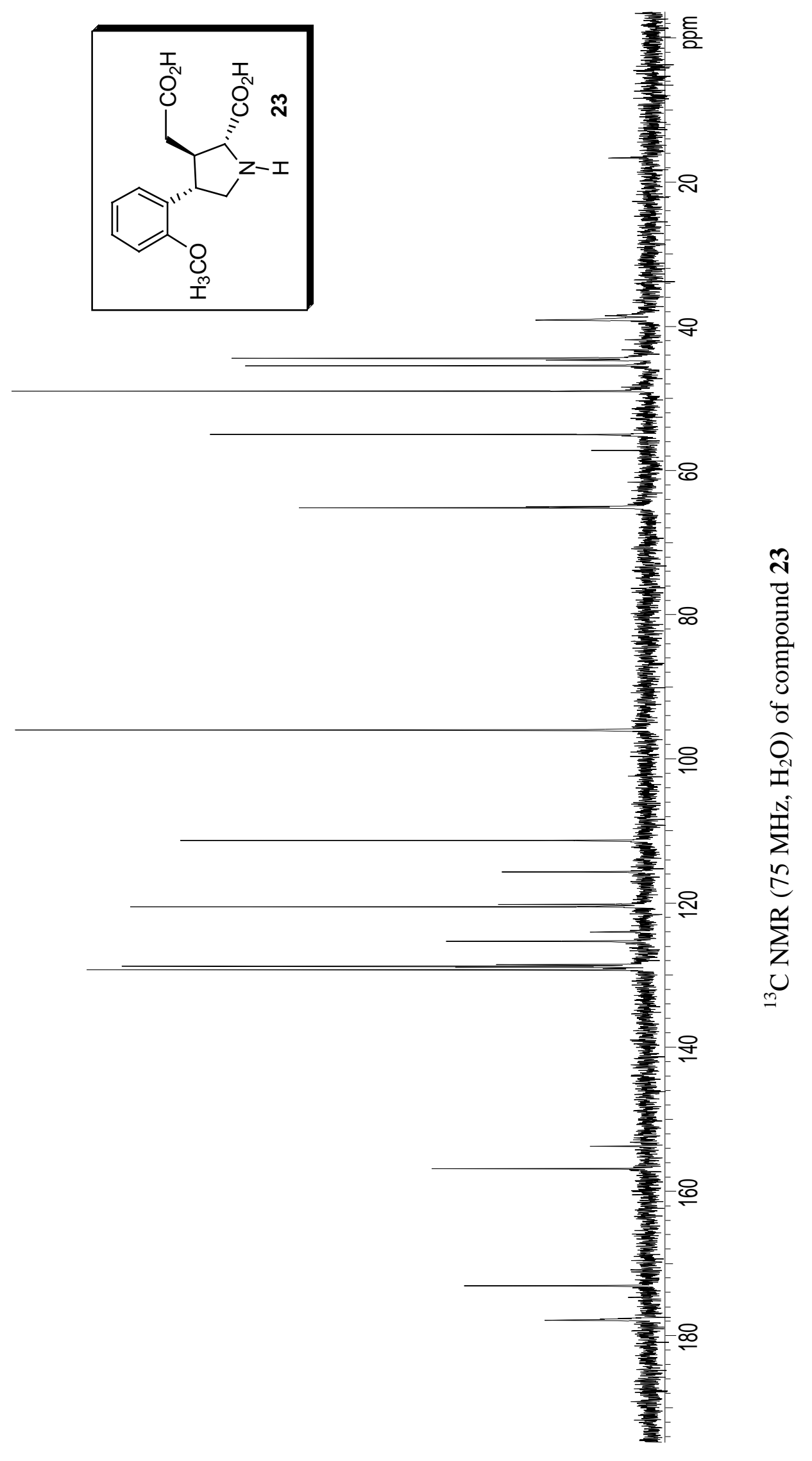




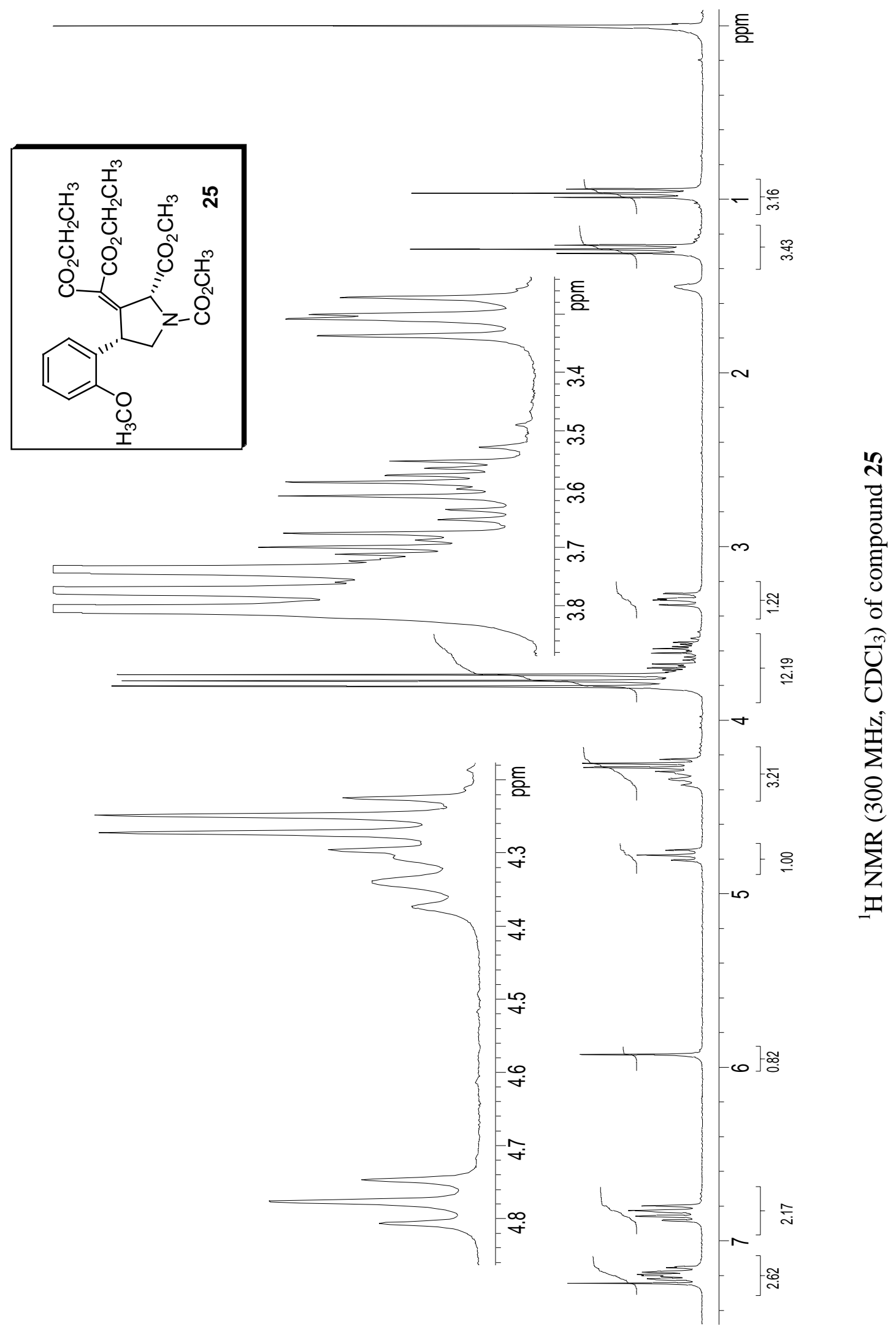




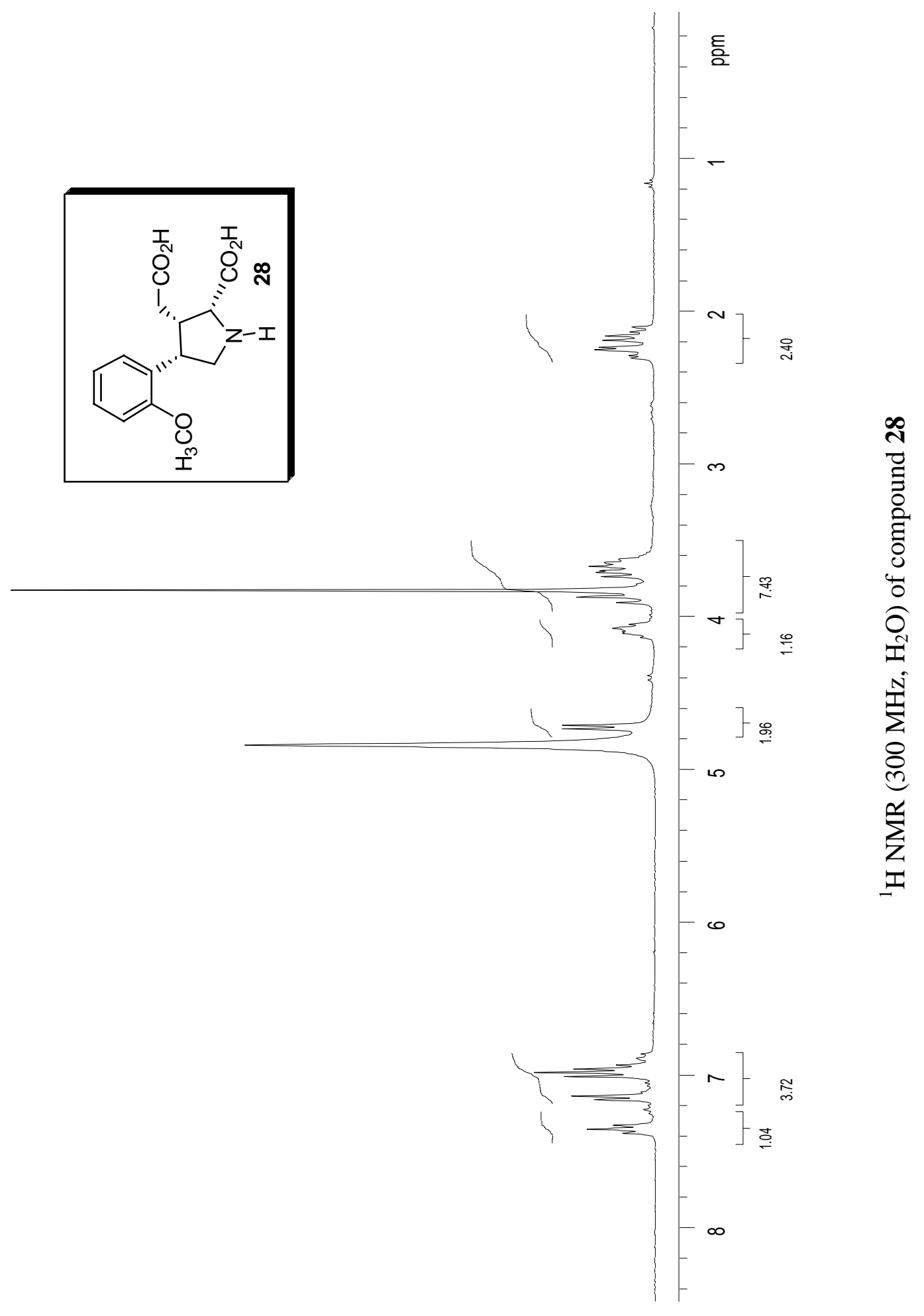



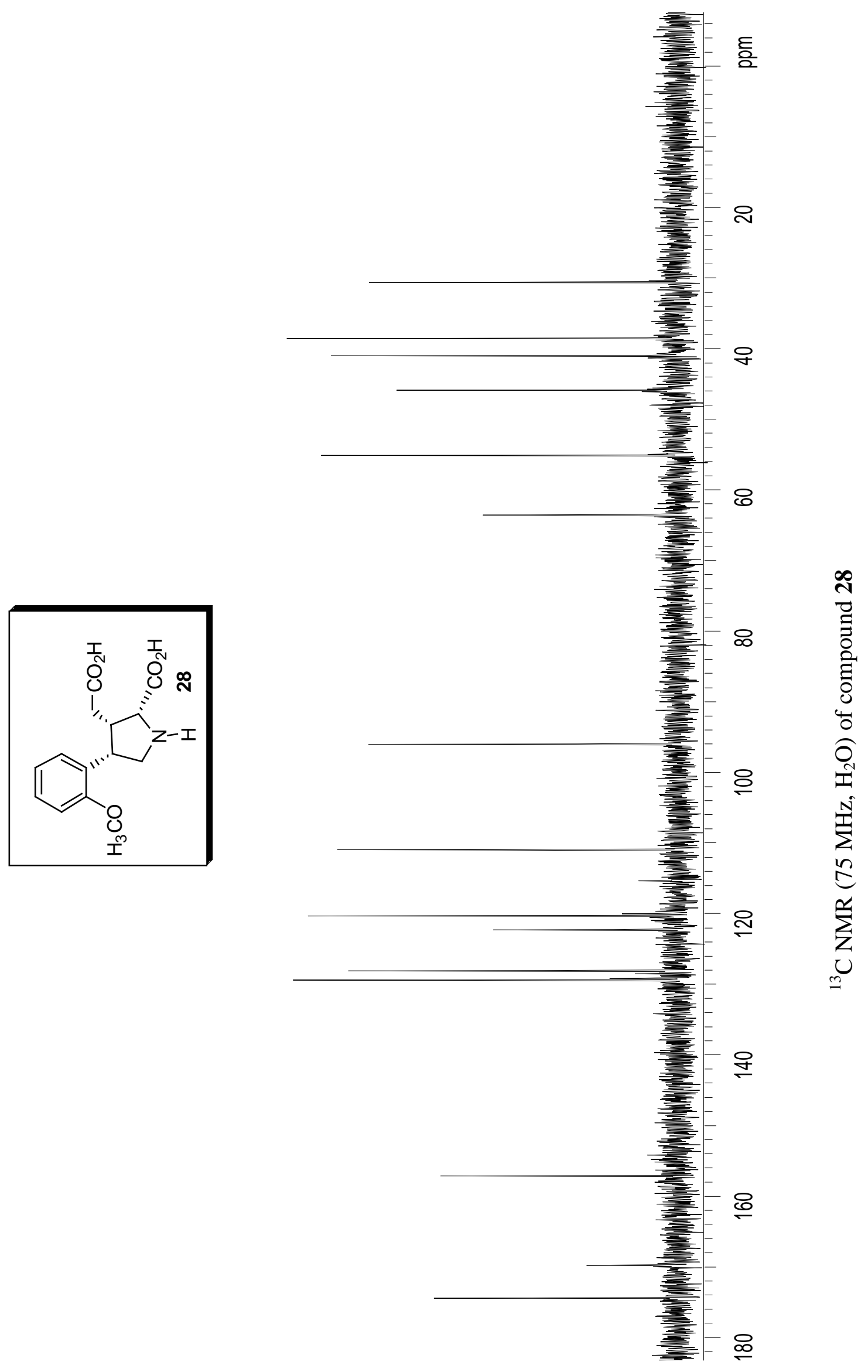


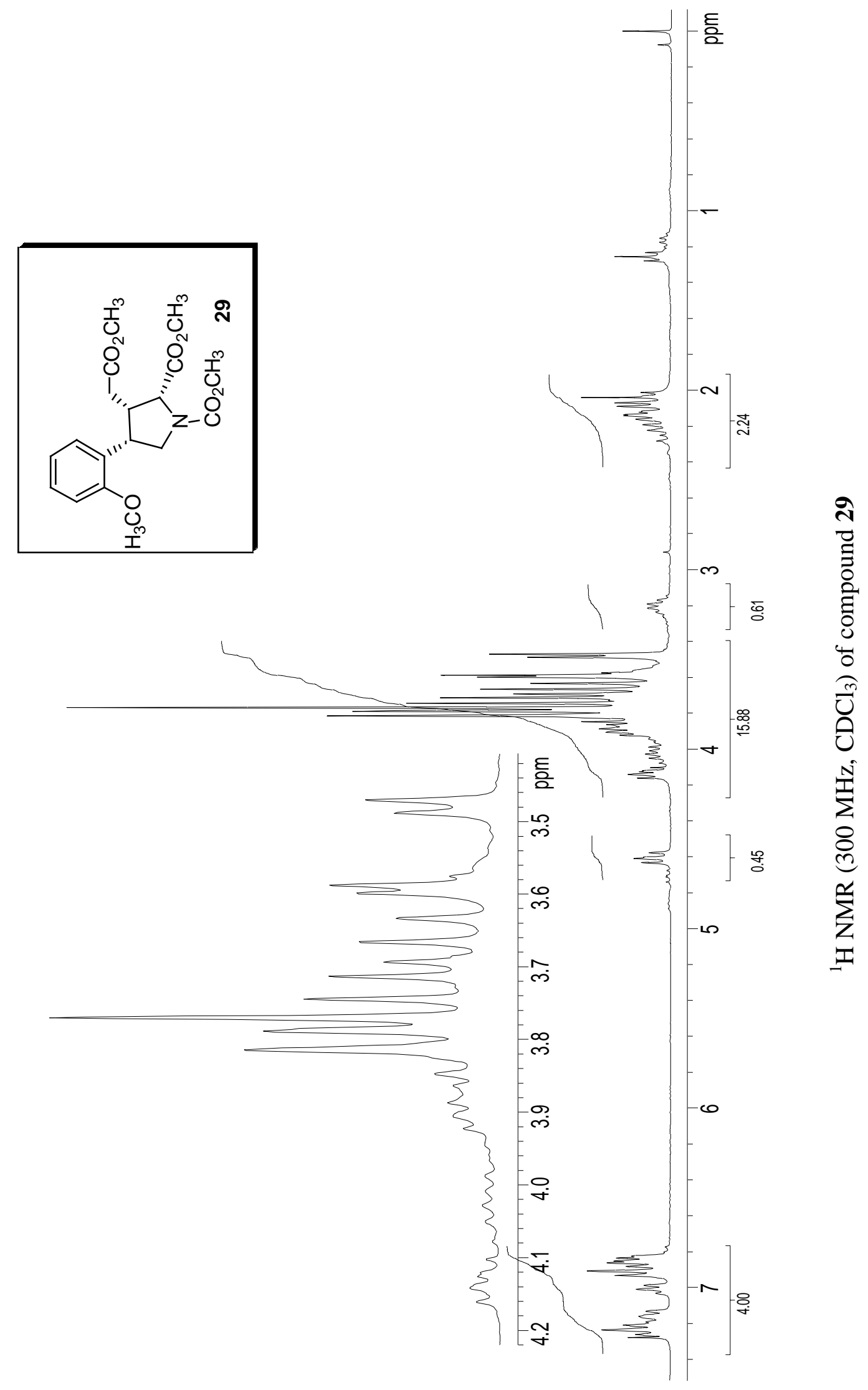




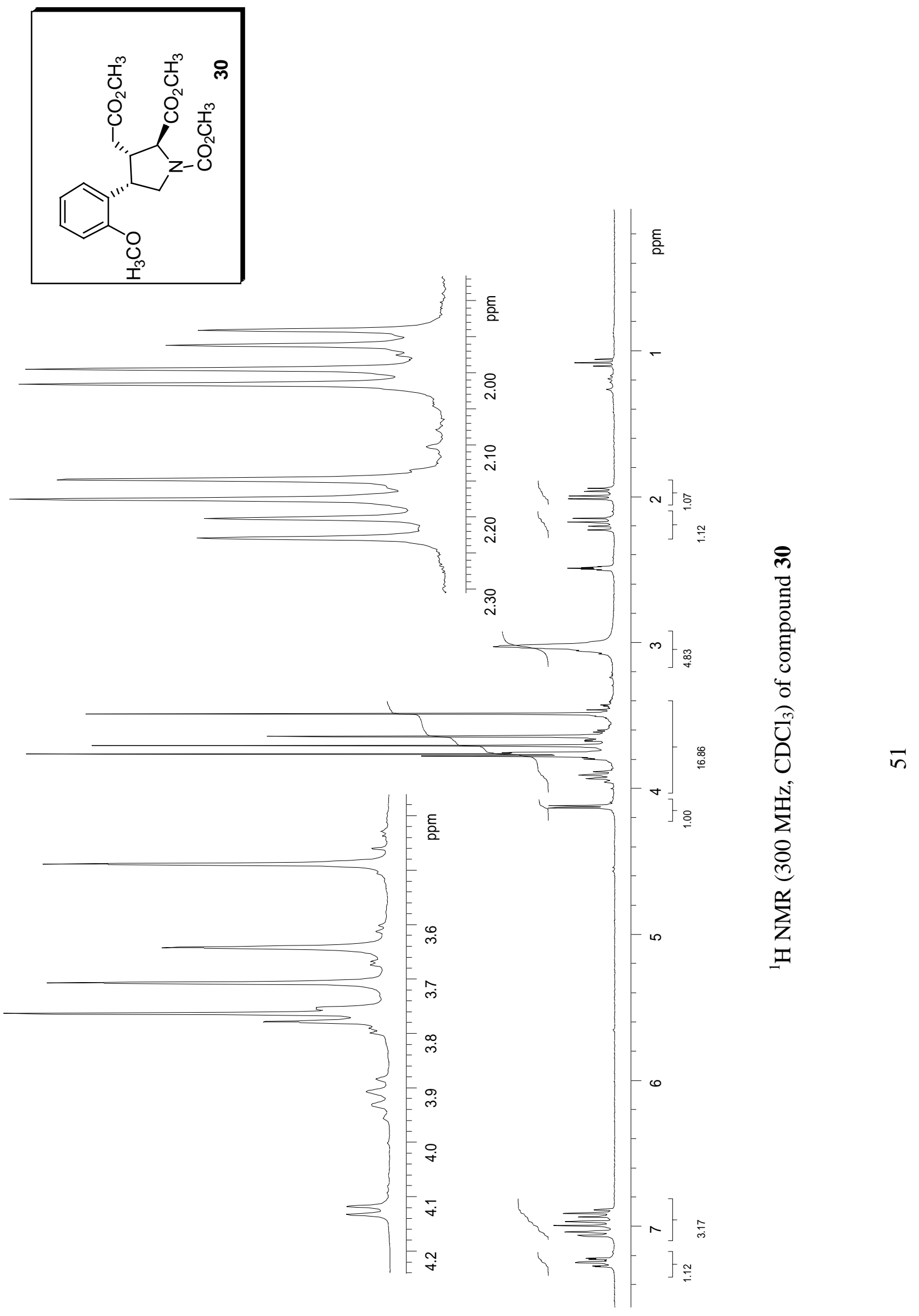




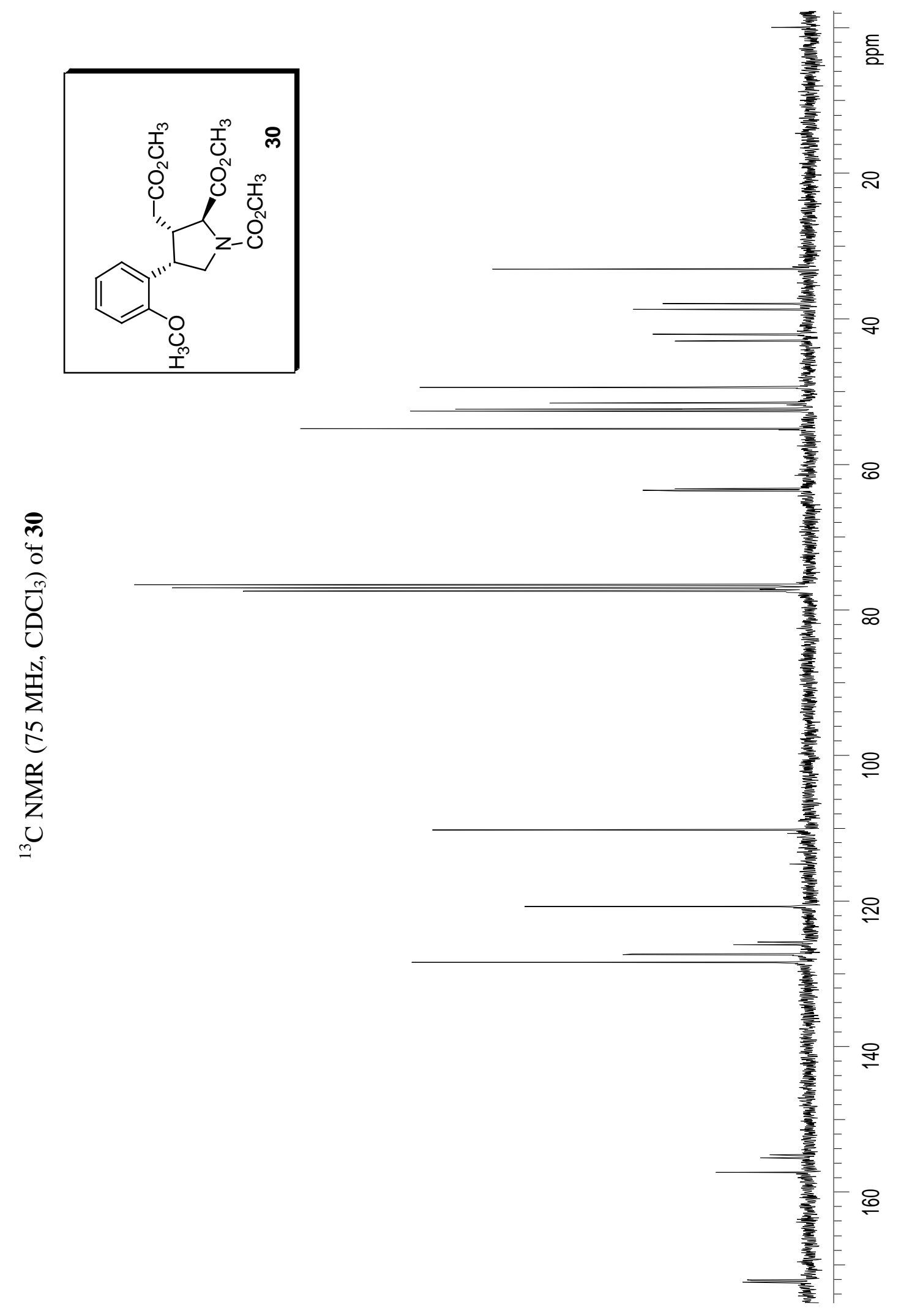



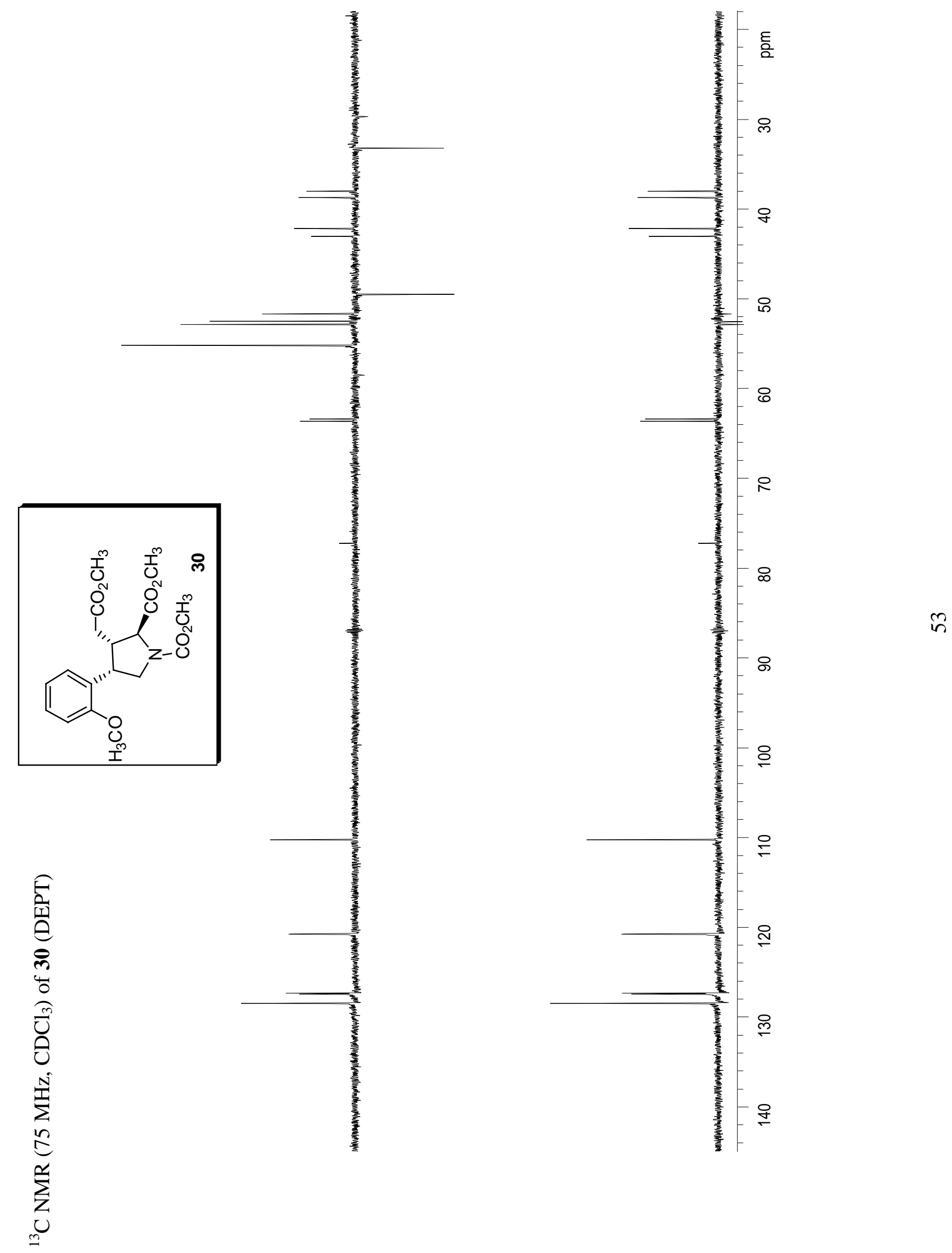


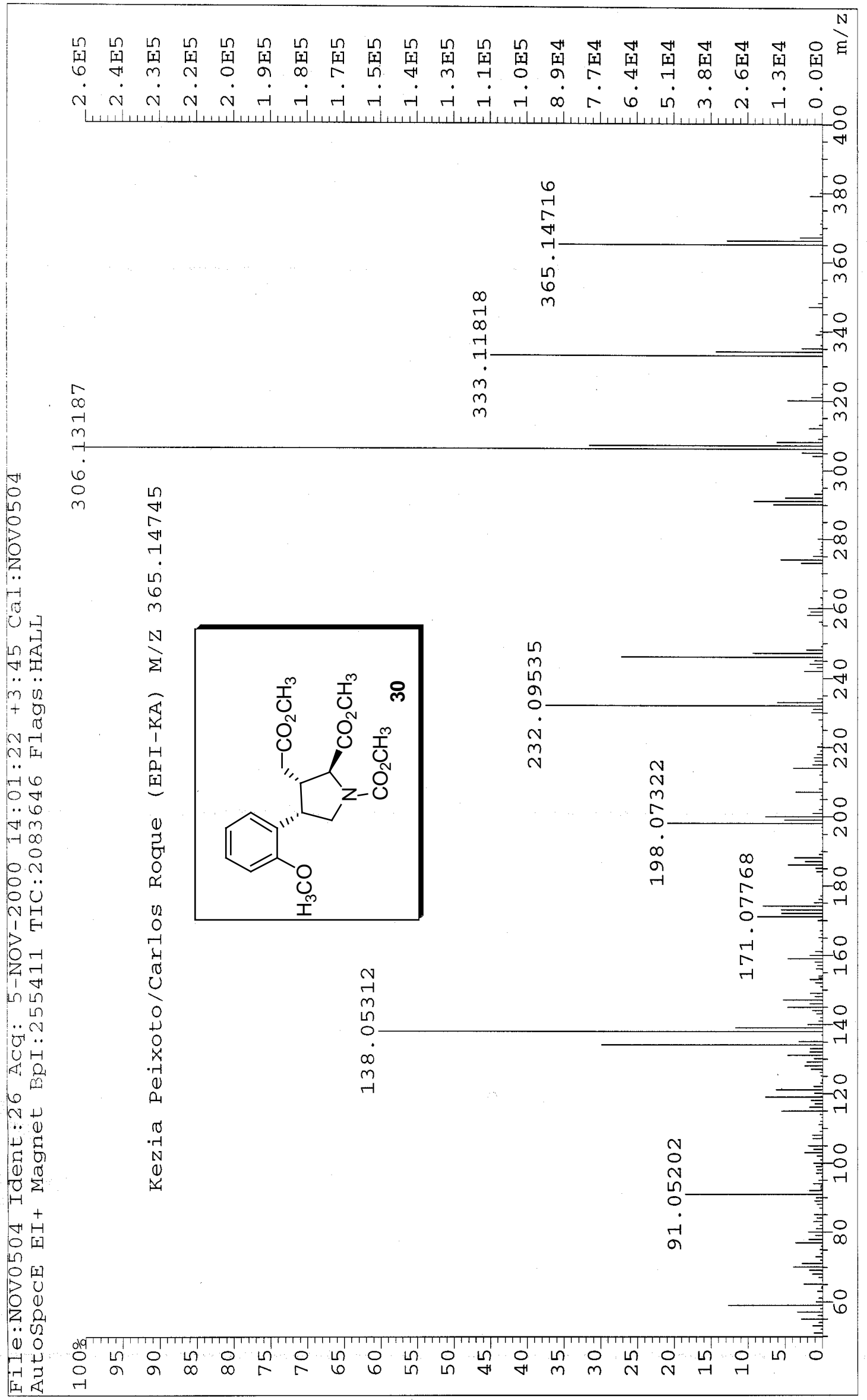




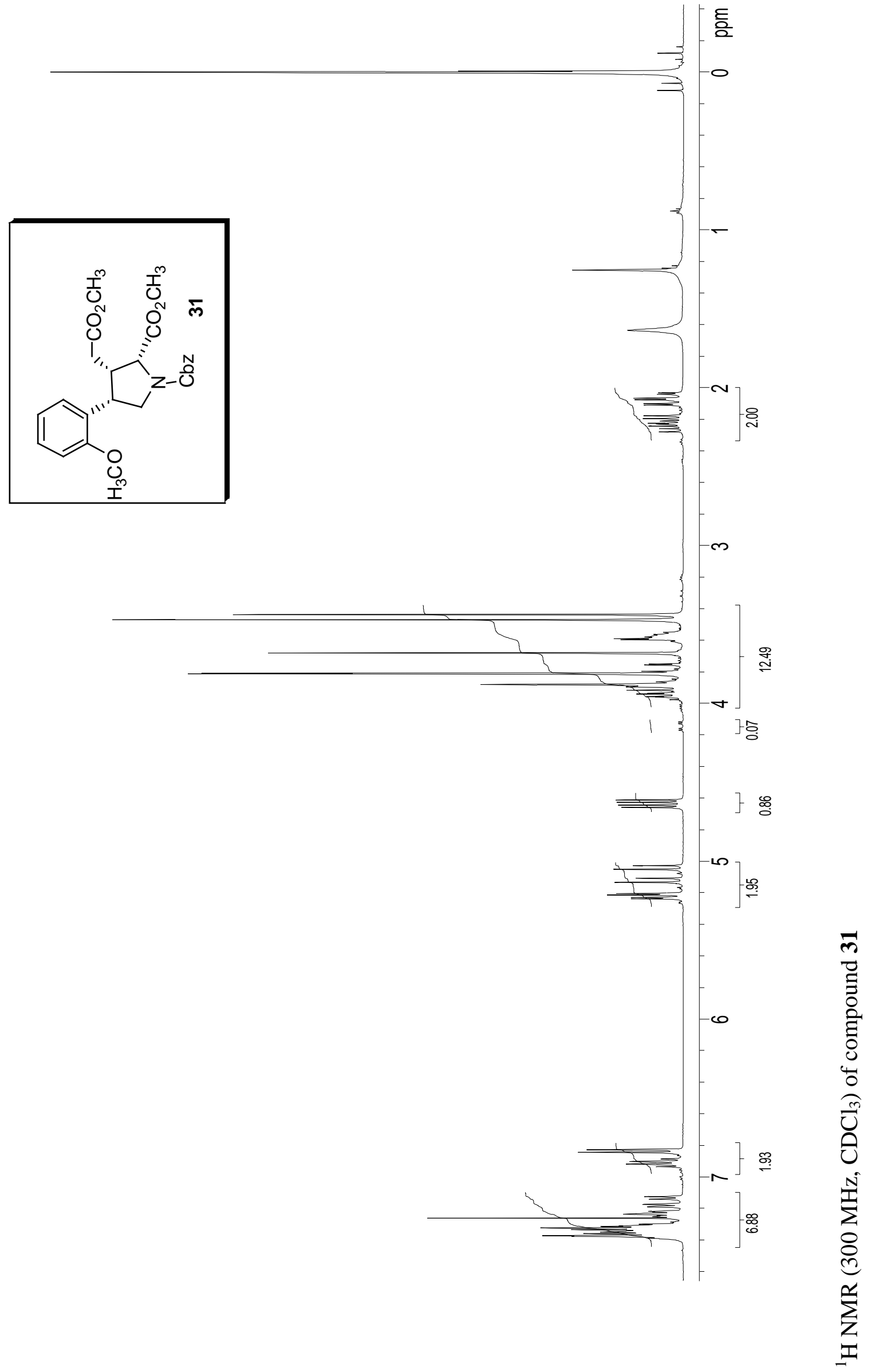




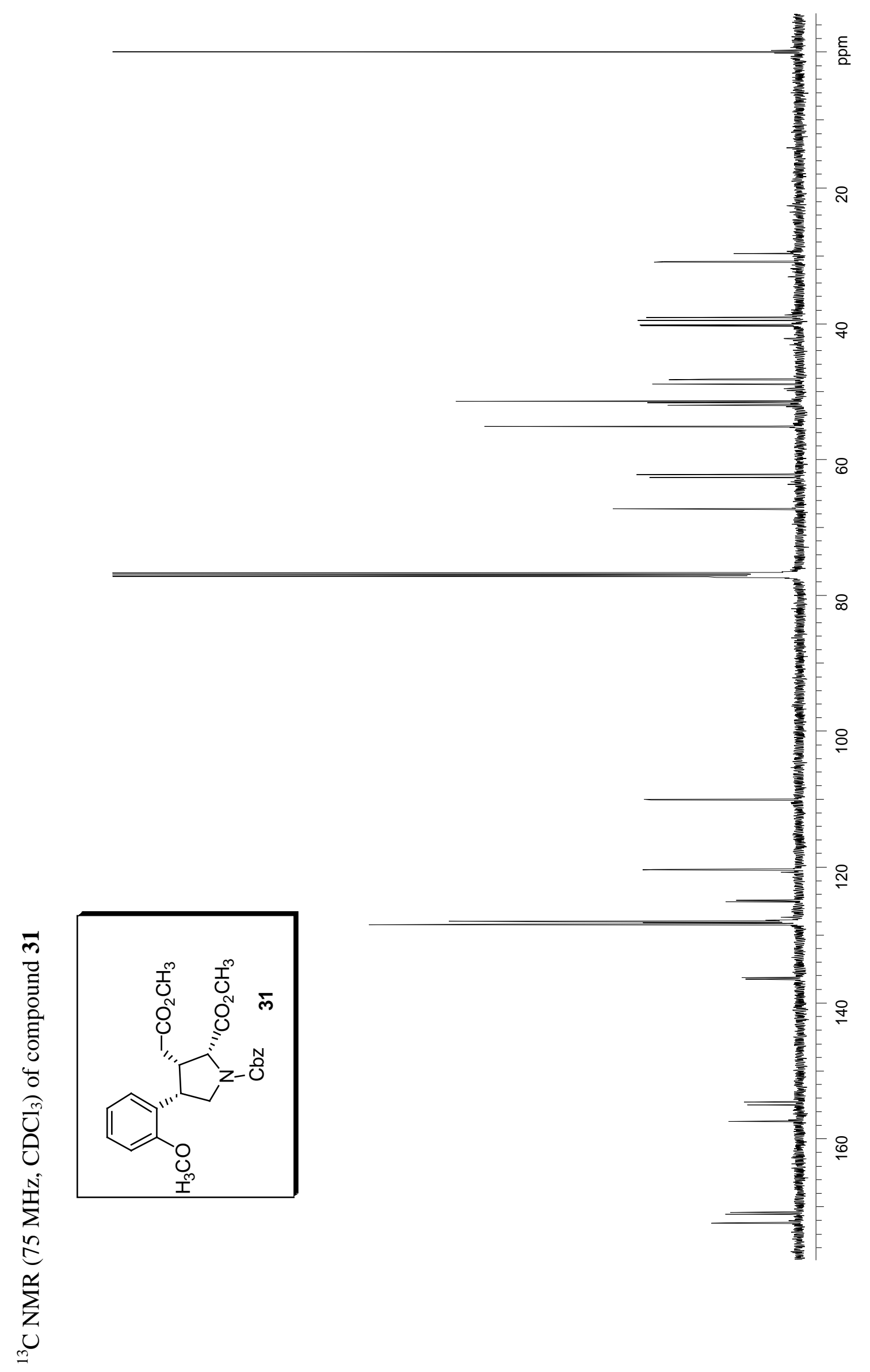




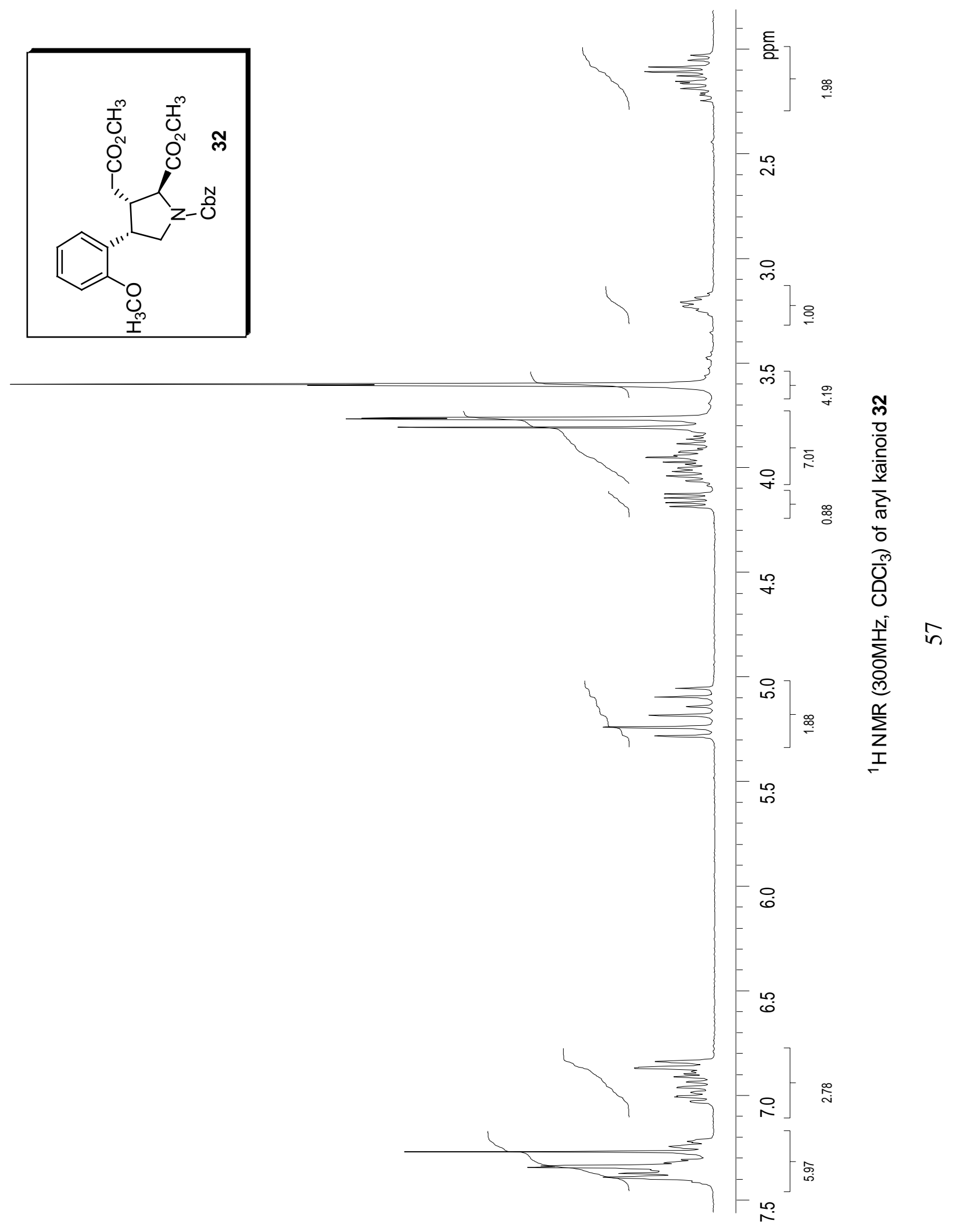




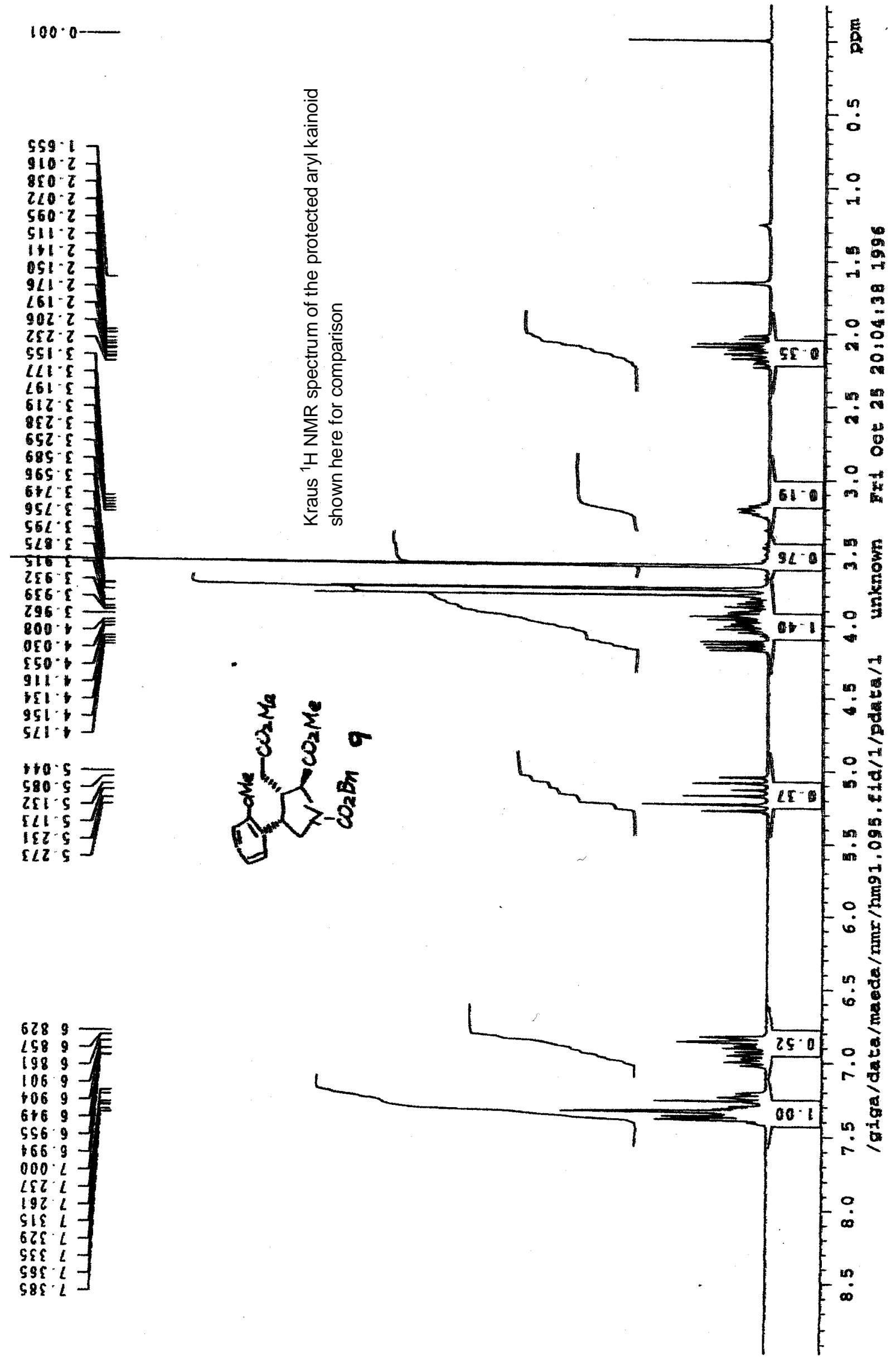




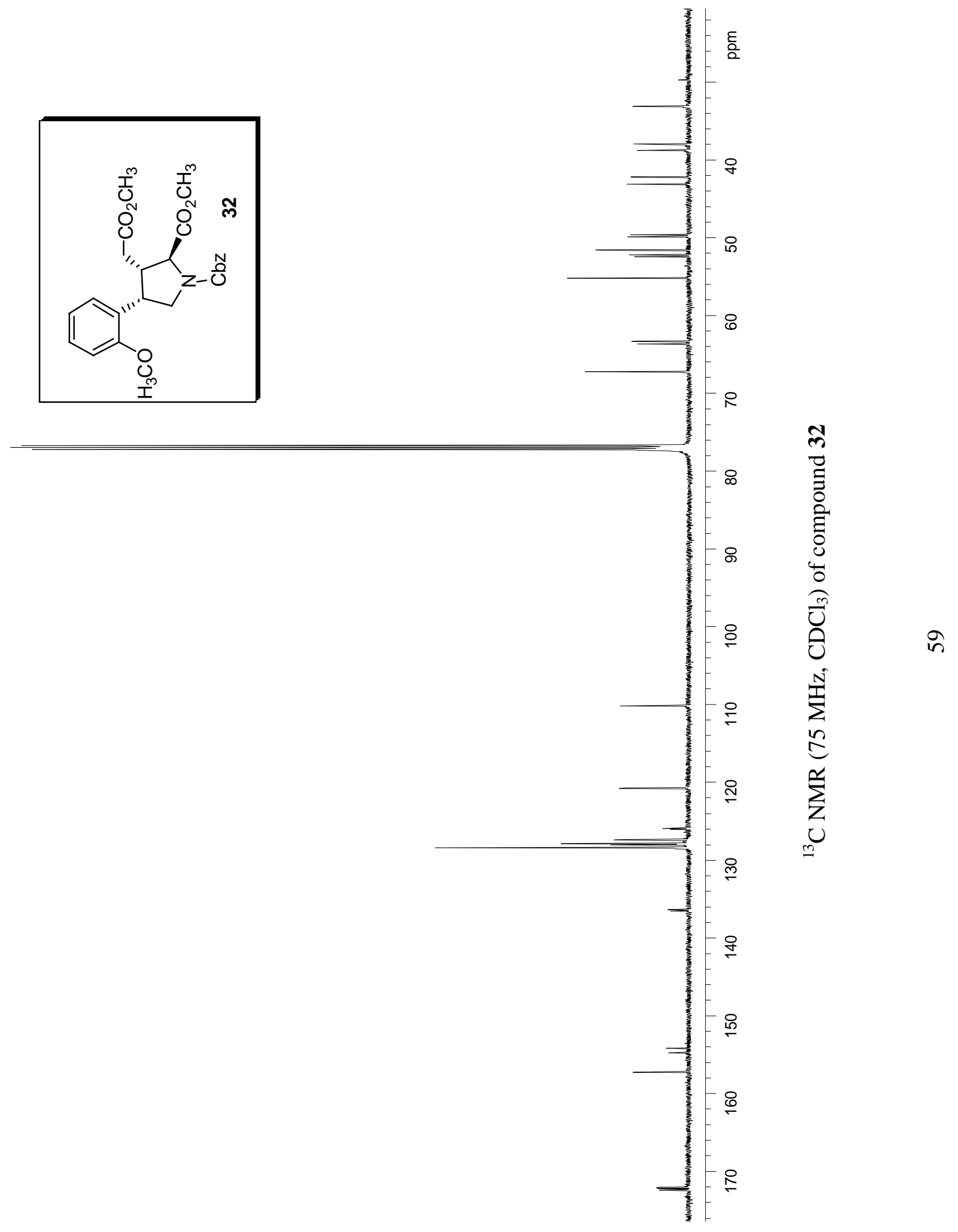




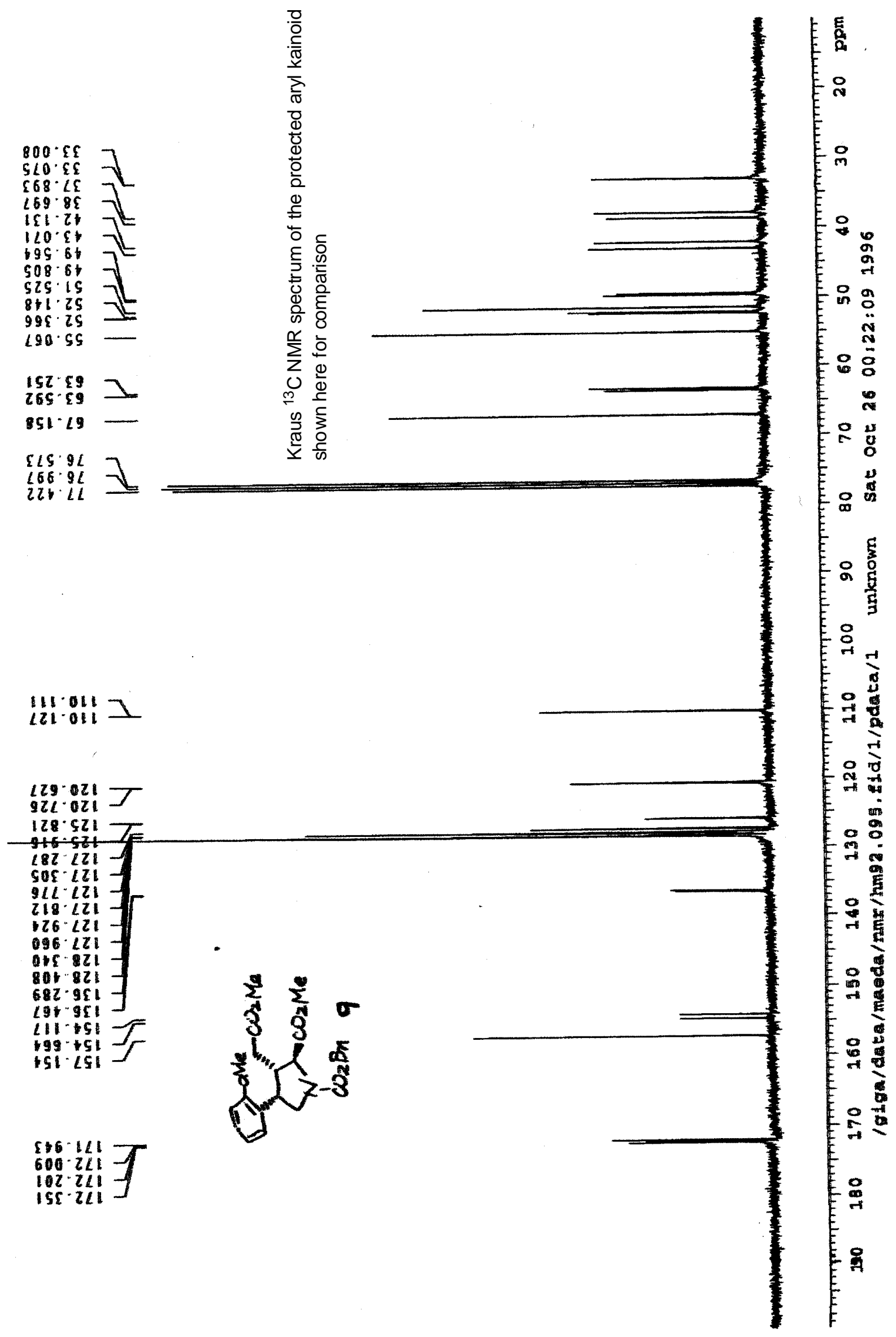




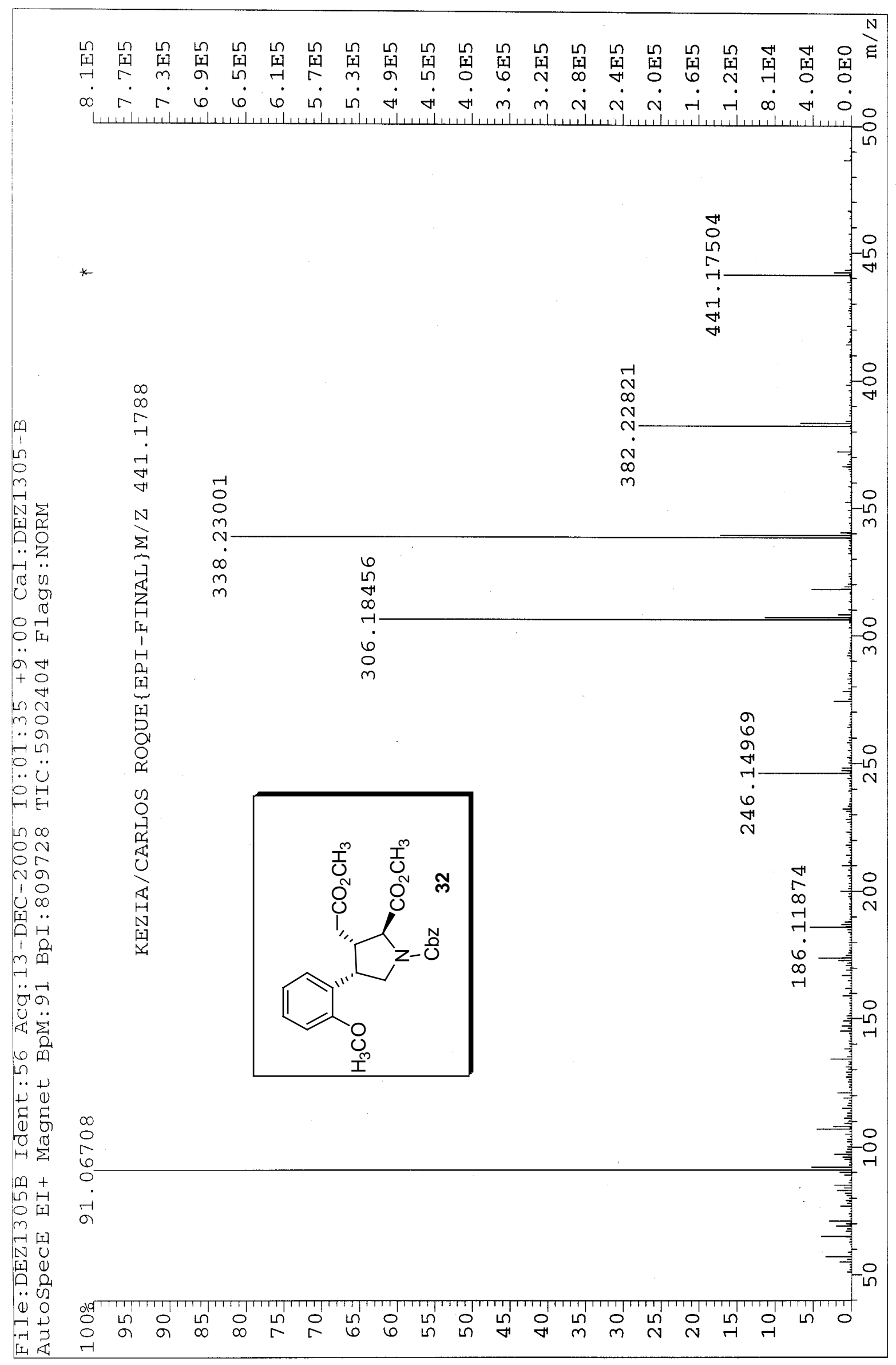

